UNITED STATES DEPARTMENT OF THE INTERIOR

Harold L. Ickes, Secretary

GEOLOGICAL SURVEY

W. C. Mendenhall, Director

Bulletin 910-C

\title{
FINENESS OF
}

\section{GOLD FROM ALASKA PLACERS}

\author{
BY \\ PHILIP S. SMITH
}

Mineral resources of Alaska, 1937

(Pages 147-272)

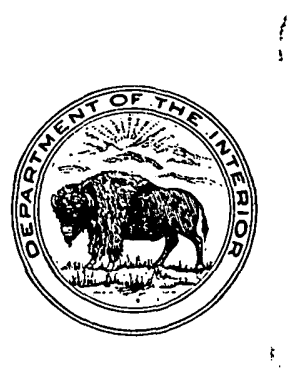

UNITED STATES

GOVERNMENT PRINTING OFFICE

WASHINGTON : 1941

For sale by the Superintendent of Documents, Washington, D. C. . . . . . Prico 30 cente 



\section{CONTENTS}

Abstract
Introduction
Definitions
Sources of information
Arrangement of information
General summary

Differences in fineness.-.-..-...-.

Metals other than gold in bullion from Alaska placers._-_.

Descriptions of regions in relation to fineness of placer gold_-_...-..--

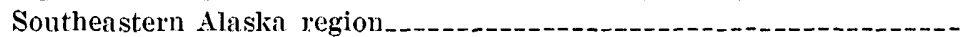

Juneau district _._.

Porcupine district_...

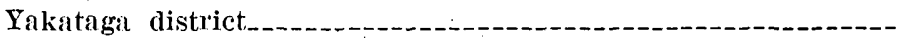

Copper River region

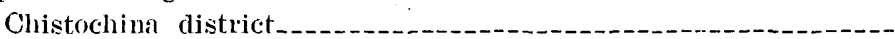

Slate Creek area__._.

Middle Fork area-__._.

Rainy creek areal-_.

Nizina district

Nelchina district

Cook Inlet-Susitna region _._____._.

Kenai district _........

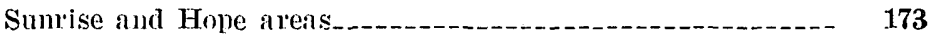

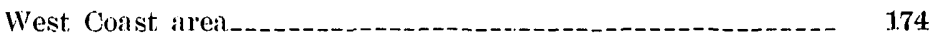

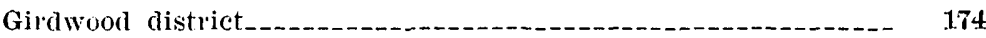

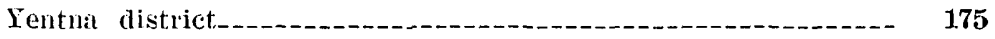

Peters Creek and Cache Creek arens_-_._-_-_-_-_-_- $\mathbf{1 7 5}$

Talkeetna area _-___._. 177

Valdez Creek district_...._._.

Southwestem Alaska region_____._._._._. 178

Yukon region_-_._-_.

Bomnifield district _._._- 179

Totatlanika area_._._.

Tatlanika area _._-

Wood River area.--_-_-_-_-_- 181.

Little Delta area

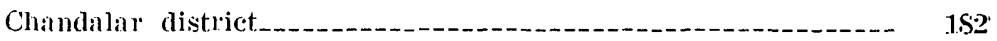

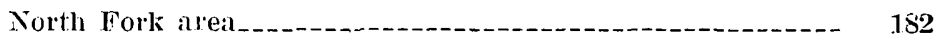

Hodzana area _-_-_-_- 183 .

Chisana district._-_.

Gircle district _-_- 184

Crooked Creek area_-_._._-_._- 185

Birch Creek area above Crooked Creek_-_-_-_-_-_-_-_-_-_ 187 .

Woodchopper-Conl Creek area____._._._._._._. 188 
Descriptions of regions in relation to fineness of placer gold-Continued. Yukon region-Continued.

Eagle district.

Page

189

American Creek and vicinity 189

Seventymile area_______._. 190

Fourth of July Creek area__._. 191

Fairbanks district _._. 191

Goldstream area ________ 192

Chatanika area_._. 193

Upper Chatanika area________. 194

Ester area

Fish Creek area____ 196

Chena-Salcha area_______._. 196

Nome Creek area____ 197

Fortymile district___- 198

Fortymile River area___. 198

South Fork area_-_._. 199

Mosquito Fork area___. 200

Walker Fork area__._____ 201

Gold Hill district__. 201

Hot Springs district____- 202

Fureka area_._. 203

'lofty area _._. 204

Iditarod districi__. 205

Otter area___. 206

Willow area___. 207

Bonanza area_-_._._. 207

Innoko district._. 207

Ophir area____._. 208

Tolstoi area___. 209

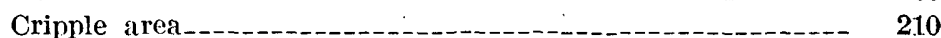

Kantishna district______-_ 211

Kantishna and vicinity

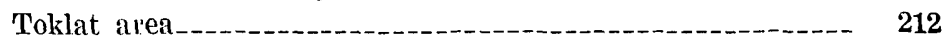

Koyukuk district._._.

Wiseman area___n 213

Marshall district__._._. 215

Fortuna area

Kako area._._. 216

Stuyahok area_____ 217

Rampart district._. 217

Minook area___. 217

Richardson district _._. 219

Ruby district_._. 219

Sulatna area _... 220

Poorman area_______. 221

Tolovana district _-_ 222

Livengood and Olive areas._._. 223

Wilbur area_._._._._._. 224 
Descriptions of regions in relation to fineness of placer gold-Continued.

Kuskokwim region

McKinley district

Nixon Fork area_.

McGrath area

Monre Creek area_____ 228

Georgetown district _._. 229

Area northeast of Georgetown______._. 230

Area northwest of Georgetown_._. 230

Kolmakof area____- 231

l'uluksak-Aniak district__- 231

Tuluksak area____ 232

Kwethluk area _..._. 233

Aniak alea _-_- 233

Goodnews district_-_._. 234

Goodnews River area_-_-_- 235

Arolic area _. 235

Seward Peninsula region_- 236

Bluff district__. 257

Council district._._- 238

Niukluk area___._._-_- 239

Fish River area__._. 240

Fairhaven district._. 240

Candle area

Inmachuk area_-_. 242

Buckland area_-_-_- 243

Kiwalik area__._._. 243

Kougarok district._-_-_._. 244

Taylor area___._. 245

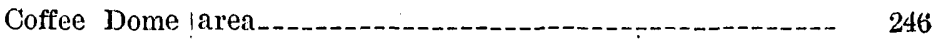

Iron Creek area-_- 246

Koyuk district__-_-_- 247

Dime area_-_._- 248

Sweepstake area________. 249

Ungalik area_-_-_-_- 249

Nome district___n_- 250

Beaches_._- 251

Snake River area__-_____ 253

Nome River area._-_._- 255

Cape Nome area___- 256

Oregon area... 256

Port Clarence district._._._. 257

Teller area_-_. 258

Agiapuk area_..._. 259

Solomon district_______. 259

Solomon River area____. 261

Spruce Creek area______ 262

Casadepaga area._._._._. 263

Northwestern Alaska region__._.______- 264

Kobuk district__. 264

Shungnak area___- 260

Kiana area_-_. 266

Index 


\section{ILLUSTRATIONS}

Plate 3. Map of Alaska showing areas differentiated in accordance with

the dominant fineness of placer gold

In pocket.

Frguke 7. Sketch map showing principal placer streams in part of Circle

district 


\title{
FINENESS OF GOLD FROM ALASKA PLACERS
}

\author{
By Philit S. Smith
}

\section{ABSTRACT}

Gold recovered from placers has alloyed with it other metals in varying proportions. The proportion of pure gold in these alloys is known as the fineness of the gold and is expressed as parts in a thousand. Thus an alloy containing 850 parts of gold is referred to as $\$ 50$ fine. Alaska placer gold ranges from more than 970 fine to slightly less than 565 fine. This report analyzes the records obtained from 1,534 determinations of the fineness of Alaska placer gold and shows that 23 percent of the records are of gold of fineness' higher than 900 ; 42 percent are between 850 and $899 ; 26$ percent between 800 and 849 ; and 9 percent of gold less than 800 fine.

In addition to this broad classification, the records are analyzed according to a number of other classifications. Thus, the quality of gold from each of the 8 major geographic regions, the 41 districts, and the 84 smaller areas are tabulated and discussed in some detail separately. 'The various modes of occurrence are compared and correlated so far as practicable with respect to geologic environment and relation to features that may have significance in affecting the fineness of the placer gold. The report affords no conclusive evidence as to the causes of the variations in fineness noted, but serves rather to bring together some of the fundamental data which, with more detailed studies of other factors, will be helpful in solving some of the abstruse problems relating to the characteristics and formation of Alaska placers.

\section{IN'TRODUC'TION}

That no native gold as it is recovered from lodes or placers is pure gold is probably well known to most people. 'That the quality of the native gold, from even rather restricted areas, differ's greatly in the ratio of the gold content to the silver and other metals that are combined or associated with it is almost equally axiomatic. If the reasons for these differences were thoroughly understood geologists would doubtless find themselves far more able than they now are to interpret some of the facts as to the distribution of the valuable minerals in the known deposits and could thus afford helpful suggestions to prospectors and others in the search for new deposits. Unfortunately data bearing on some of these relations are not available at all and others have not been brought together in readily accessible form. Among the significant items that belong in the latter category 
is the ratio of gold to other metals in the valuable material recovered from Alaska placers. To supply some information on that subject is the object of this report.

The ratio of gold to other metals in the placers is readily recognized as but one of the factors among many that merit consideration, and the results set forth are merely contributory to the larger problems rather than ends in themselves. In other words, these records are of value chiefly as they may stimulate further inquiry as to the underlying reasons for such great differences in the gold content of the gold-bearing material from placers in the various parts of Alaska. Further studies along the lines covered by the present report would call for the analysis of much smaller areal units than those discussed here, as well as the collection of many times the number of individual records for most of the tracts. The proper interpretation of the present information, as well as of the subsequent information that should be gathered along the same general lines, touching as it does only the fringes of the major problems, should be followed up by diverse investigations along many other lines. For instance, among the chemical or mineralogical studies that should be made are more numerous and more detailed analyses of the associated metals and of the dross and thorough determination of the mineralogical composition of the heavy concentrate recovered with the gold. In addition, studies should be made of the physical character of the metallic elements and their relations to each other in the valuable material recovered and the form and size of the particles or masses. It is also highly important that each of these characteristics be closely referred to the geologic environment in which the material occurs, not only as regards the specific deposit from which the material is obtained but also as regards remote areas that may have been influential in supplying the material or in affecting its concentration or modification. ${ }^{1}$

\section{DEFINITIONS}

In order that certain technical terms used in this report may be understood in the sense in which the writer has used them, the following statements may be in order. The term "fineness" as used in this report does not relate in any way to the size of the particles of gold. Fineness as used in this report and as defined by the Century Dic-

\footnotetext{
'Some time after the accompanying report was written, J. B. Mertie, Jr., long identined with the Alaska work of the Geological Survey, delivered an address on Placer gold in Alaska, a subject which he is eminently qualified to discuss. Mertie presents, among other things, many significant observations on the fineness of gold from Alaska placers, which should be considered in relation to some of the statements in the accompanying report, especially because his interpretations differ somewhat from some of the suggestions made here. See Mertie, J. B., .r.. Placer gold in Alaska: Washington Acnd. Sei. Jour., vol. 30, pp. $93-124,1940$.
} 
tionary is specifically the quantity of pure metal in alloys expressed by number of parts in 1,000. It will thus be seen that the term "fineness" is in a way comparable with the term "percent," except that percent refers to parts in a hundred whereas fineness refers to parts in a thousand, and, of course, percent is not restricted to alloys. In written form fineness should be expressed in figures without any decimal point, unless it is necessary to show amounts smaller than one-thousandth part. Thus the correct usual form is 880 or 835.2 fine, and not .880 or .8352 fine, the latter two examples would indicate $\frac{880}{1000000}$ and $\frac{8352}{10000000}$ parts, respectively.

Many stages of mining, separation, and refinement intervene between the occurrence of gold-bearing material in natural placer deposits and the final separation of the gold from less valuable material with which it was associated. It is not necessary here to enumerate all these stages, but as the material obtained at four of the stages has special significance in the present study some mention of them is worth while at this point. The original tenor of placer material is generally referred to in terms of its value a pan, a cubic yard, or a square foot of bedrock, and the price stated includes all the valuable metals recovered. The measurement by the pan is a rather rough, primitive method that is generally applicable because of its simplicity and universal availability. Although differing greatly in actual practice, a "pan" is usually estimated as representing about one one-hundredand-fiftieth of a cubic yard, so that tests yielding 1 cent in valuable metals to the pan would indicate a content of around $\$ 1.50$ a cubic yard. The use of the system of expressing the value of placer deposits in terms of square feet of bedrock came about largely through the generally recognized fact that many pay streaks are closely restricted to a relatively thin zone close to bedrock and that the overlying material, which in places is 100 feet or more thick, might be disposed of without undergoing the usual processes of sluicing and yet without materially affecting the amount or value of the metals recovered from the tract.

The many methods developed for getting the valuable metals from their disseminated state in the natural placers range from simple methods requiring pick and shovel or pan to most elaborate methods requiring highly mechanized plants. In essence, however, all have for their object the excavation of the placer material, the separation by difference in gravity of the valuable material from the worthless, the retention of the valuable product, and the rejection of the waste. It is manifestly impossible and undesirable in commercial practice to make an absolute immediate separation of all the valuable material from the waste, and consequently the practice is to stop the first stage of the 
process before all the heavy waste material has been removed and before a significant amount of any of the valuable material has been allowed to escape. This marks the end of the first stage of mechanical separation. The resulting product is then very carefully rehandled under more critically controlled conditions so as to separate further as much as possible of the valuable material from the worthless. This process is generally known as the "clean-up," and the product is known by the same term. The metallic portion is usually given the colloquial designation "dust" if it has been collected without the use of mercury and "amalgam" if mercury has been used. Even the most careful washing, blowing, and magnetic separation of the clean-up often fail to remove all particles of foreign material from the dust, so that when this product is offered for sale or is to be further refined, some estimate must be made of the true amount of the recoverable metallic content. This difference in thoroughness of preliminary cleaning causes the banks or other purchasers to make different advances for different lots of gold even if ultimately it should prove that the fineness of the gold in each was the same. Even the cleanest crude dust, however, is seldom free of some waste, which shows up in the assay reports as the difference between what is usually reported as "weight before melting" and "weight after melting." Even in well-prepared clean-ups this loss may be as much as 1 percent. When the valuable part of the clean-up has been melted, the waste products have joined with the flux to form slag, and the valuable metals have coalesced, the metallic portion, consisting mainly of gold and silver, forms what is called bullion. Usually the bullion is poured into molds, where it solidifies into bars. After this stage the bars are tested to determine the fineness of the bullion, that is, the precise proportion of gold and silver they contain. The tests are made on small samples cut or drilled from various parts of the bar so as to be representative of the bar as a whole, and on the results of the tests financial settlements are made. In the following pages the fineness stated is based almost entirely on the results obtained by the banks, assay offices, or mines on the various lots of gold submitted to them after having been melted down to crude bullion. The last step may be the separation or "parting" of the gold from the silver in the crude bullion, resulting in a product of theoretically pure or fine gold and pure silver.

To compute the money value of gold of different fineness it is evident that, as in all decimals, it is only necessary to perform the simple arithmetical process of multiplying the stated fineness of gold as thousandths by the current price of gold an ounce and adding to this the result of multiplying the stated fineness of silver as thousandths by the price of silver an ounce. Thus, in 1937 an ounce of bullion 850 fine 
gold and 145 fine silver was worth $(.850 \times \$ 35)+(.145 \times \$ 0.77),{ }^{2}$ or approximately $\$ 29.86$. In this example it will be noted that the sum of the parts of gold and silver does not equal 1,000 but 995 leaving 5 parts unaccounted for. The part unaccounted for is composed usually of copper or some other metal whose unit value is so low that the metal is not worth recovering and would not affect the price per ounce of the bullion.

Mention of the method of converting fineness figures into price per ounce is relatively inconsequential in the present discussion, but it is introduced because many miners are mystified by the apparent juggling of figures shown by the reports they receive from purchasers of their dust. In the above example it will be seen that whereas it is true that bullion of the fineness stated would be worth $\$ 29.86$ an ounce, the dust before melting would be worth only $\$ 29.71$ an ounce if it were cleaned so as to lose one-half of 1 percent in the course of being melted and would be worth only approximately $\$ 29.26$ an ounce if it lost as much as 2 percent during melting; and the gold alone in the bullion 850 fine would be worth only $\$ 29.75$. The foregoing figures relate solely to the full value of the gold and silver in the dust or bullion and do not include any charges for handling. Obviously a bank or merchant purchasing crude dust or bullion would not be justified in omitting handling charges, because the costs for shipment, insurance, loss of interest on advances made, melting, and mint or assay office treatment must be taken care of as inescapable expenses by the purchaser if he is to avoid unwarranted loss. To cover these expenses the private purchasers often, instead of showing these items as direct charges, will merely deduct a predetermined amount from the full theoretical value of the dust or bullion and allow the resulting amount as the price per ounce of the material, a practice that makes many sellers feel that they are not receiving full value for their product.

\section{SOURCES OF INFORMATION}

Although all sources of information immediately available in the Geological Survey have been utilized in formulating the statements made in the accompanying report, the principal new feature presented is the bringing together in one place of many items that heretofore have been scattered through many reports, and the tabulation and analysis of certain records that had not been assembled in this form. These records consist of somewhat more than 1,500 individual

\footnotetext{
2 The silver In all these computations has been culculated at a price of 77 cents an ounce. which was the official price set for all silver purchased by the Government in 1937 that qualified under the existing Executive order relating to newly mined silver derived from Arerican sources.
} 
reports from mining operators throughout the Territory. The method of obtaining these records has been such that they may well be regarded as random selections and treated as such in any mathematical analysis. Fundamentally they consist of all the specific reports relating to the fineness of gold from identifiable small tracts that have been furnished to the Geological Survey by placer-gold producers in Alaska during the past 30 years or more. In order to avoid the possibility of injecting a personal element by using only records that might fit in with some preconceived idea no selection was made but every available record was tabulated unless, as in the case of three or four, they presented obvious inconsistencies or errors, such as totaling more than 1,000 fine or falling very far below that figure.

It has long been the practice of the Geological Survey to send each year to each individual or company engaged in mining in Alaska a form on which the operator is asked to report various facts relating to his current mining operations or those of the company he represents. Among the questions on this form are several that are designed to elicit information as to the quantity and relation of the gold and silver produced and that can be satisfactorily answered for the yearly production estimates as crude dust, crude bullion, fine gold, or in any other form that will permit the Geological Survey to compute the value of the output in the form it has adopted for its statistical reports. For the purpose of the present study, however, such crude approximations as are afforded by this record of the price paid the producer for a specified quantity of dust are not sufficiently exact; therefore thousands of these reports that did not give specific data on the fineness were not utilized. Furthermore, of the thousands of records that are available to the Geological Survey from reports of the Federal mints and assay offices usually few afford geographic data exact enough as to the source of the material treated so that they could be used directly. Indirectly, however, the determinations made by these Federal offices are probably the bases of most of the records utilized in this report, because the analyses they made and reported to the producers doubtless in large measure are identical with such specific records of fineness as the producers subsequently reported to the Geological Survey on the questionnaires referred to.

That the records thus used are actually of extraordinary accuracy has been abundantly demonstrated by the remarkable consistency of the records received from many different producers in a restricted area and covering a number of years. For example, the fineness of gold from Willow Creek, in the Iditarod district of the Yukon region, as shown by 23 annual reports covering the years $1919-36$ with the 
exception of 1924,1927 , and 1935 , for which the necessary specific records are not available to the Geological Survey, has ranged between 864 and 883 , a variation of only 20 points or 2 percent. Comparable records might be cited for scores of other placer tracts in Alaska.

Although most of the records that have been used afford information as to the quantity of bullion as well as its fineness, weighting the individual reports by the quantity involved has not been considered necessary because the principal purpose of this study has been to determine not the average fineness for all the gold that has come from a certain area but rather the dominant character of the gold and its. range in fineness. For this reason each observation has been treated as though of equal weight in serving as an illustrative sample of the fineness of gold in a particular area.

\section{ARRANGEMENT OF INFORMATION}

This study requires a systematic method of presentation in which similar records may be compared and dissimilar ones may be contrasted. In this way a groundwork will have been prepared from which deductions can be drawn as to the canses for the variations. For greatest convenience, a geographic order has been adopted, starting with the southeastern part of the Territory and proceeding successively toward the northwest. The principal geographic divisions are more or less self-explanatory and conform with the usual Geological Survey practice. The largest geographic divisions correspond, on the whole, to the major areal features of the Territory. According to the usual Survey practice these are called regions, such as Yukon or Kuskokwim region. The next smaller subdivisions, called districts, are rather ill-defined, their limits having been so drawn as to bring together certain related tracts and separate other less closely related tracts. These limits have been set mainly as matters of convenience rather than in accord with any formal authority, though they do conform in general to the equivalent subdivisions that have long been adopted by the Geological Survey in its regular mineral resources studies. The subdivisional units within the districts are designated areas. Each area consists of a tract that through certain geographic position, geologic environment, or some distinctive feature as to the character of gold recovered from its placers seems to merit separation from other parts of the district. There has necessarily been a compromise, on the one hand, between distinguishing as a separate area each tract that in some measure differs from other areas and, on the other hand, disregarding minor differences and grouping together as 
large a tract as possible. In order that significant differences should not be obscured it is obviously desirable that large tracts should be broken up into a number of small areas, but this would prove to be unduly cumbersome and might obscure resemblances. To avoid the objectionable features of either extreme, on the whole, a somewhat intermediate position between these two has been adopted, though the leaning has been against rather small subdivisions. In spite of this trend, it will be apparent that for some districts an area has been set up even where only one record of fineness was available on which to base such action.

Each of the various geographic subdivisions is defined and described in some detail in the later pages of this report, where such geologic and geographic facts as may have a bearing on the fineness of the gold in their deposits are set forth. For a more generalized summary of the characteristics of the fineness of the gold from the different areas, the accompanying diagram (pl. 3) and tabulations of the available records have been prepared. The diagram indicates the distribution of the areas in Alaska for which records of the fineness of placer gold are available. Furthermore, on this diagram has been indicated graphically, by appropriate symbol, the dominant fineness of gold as determined by the records available. It should be realized that the representation possible on a diagram of this size has necessarily led to extreme condensation or elimination of many facts that are amplified in other parts of the report.

\section{GENERAL SUMMARY}

The principal facts shown by the records of the fineness of gold in the different areas are listed in the accompanying table. This table, it should be noted, relates only to the reports now available to the Geological Survey and should be used with full realization of that limitation. The headings of the various columns in the table are self-explanatory. Attention is called, however, to the column showing the number of records considered, for obviously a small number of records is less likely to show the true chäracteristics of the fineness than a larger number of consistent records. Nevertheless, even a single record is of much significance as a definite fact and, if a truly representative specimen, should give a reasonably close approximation to the general material of the area from which it was derived. As has already been noted, it has been repeatedly proved in this study that the approximate average of several observations may usually be determined by inspection with remarkable closeness to the weighted average as obtained by the more laborious computations. In fact, it is believed that the error that may 
arise through this simple method is well within the range of error that arises through the inadequacy of the data analyzed. In other words, while the mathematical accuracy of any deductions drawn from a rigorous analysis of the data set forth in the table may be open to question, it is believed that the general facts disclosed are, in the main, truly representative and closely approximate the real conditions prevailing in the areas considered. 


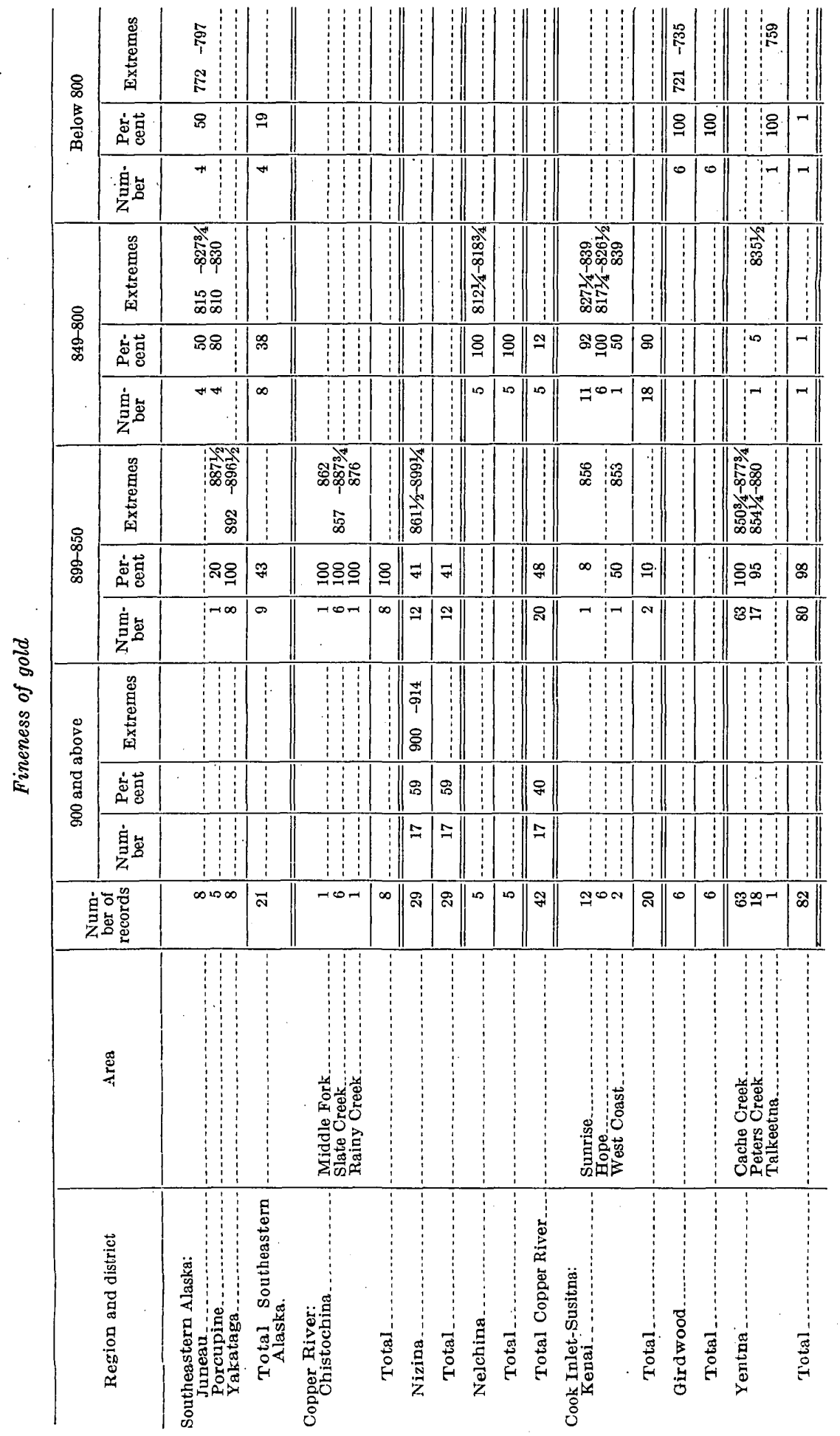




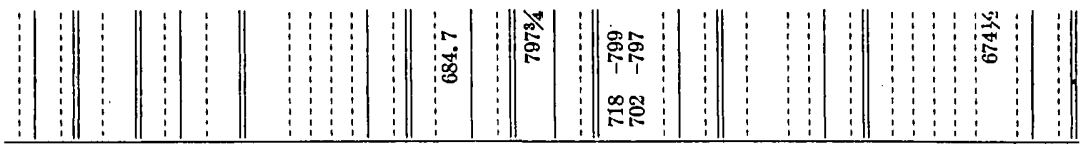

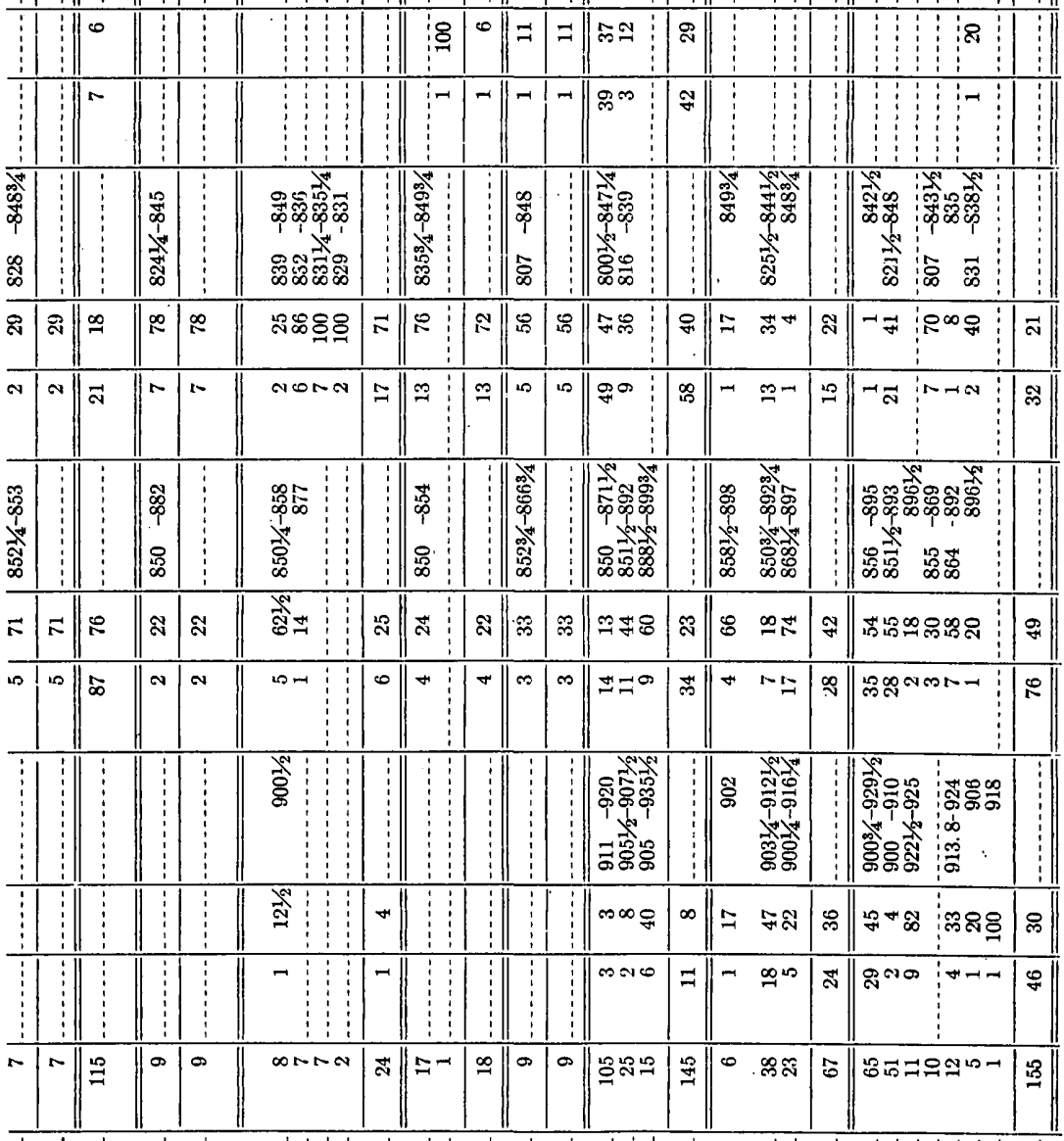

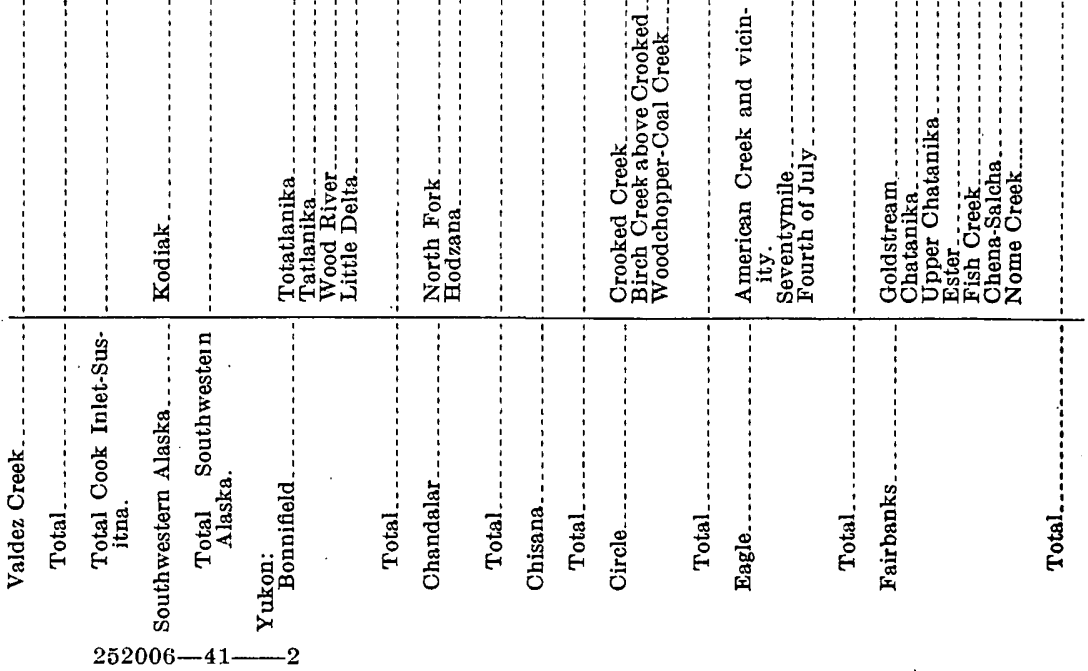




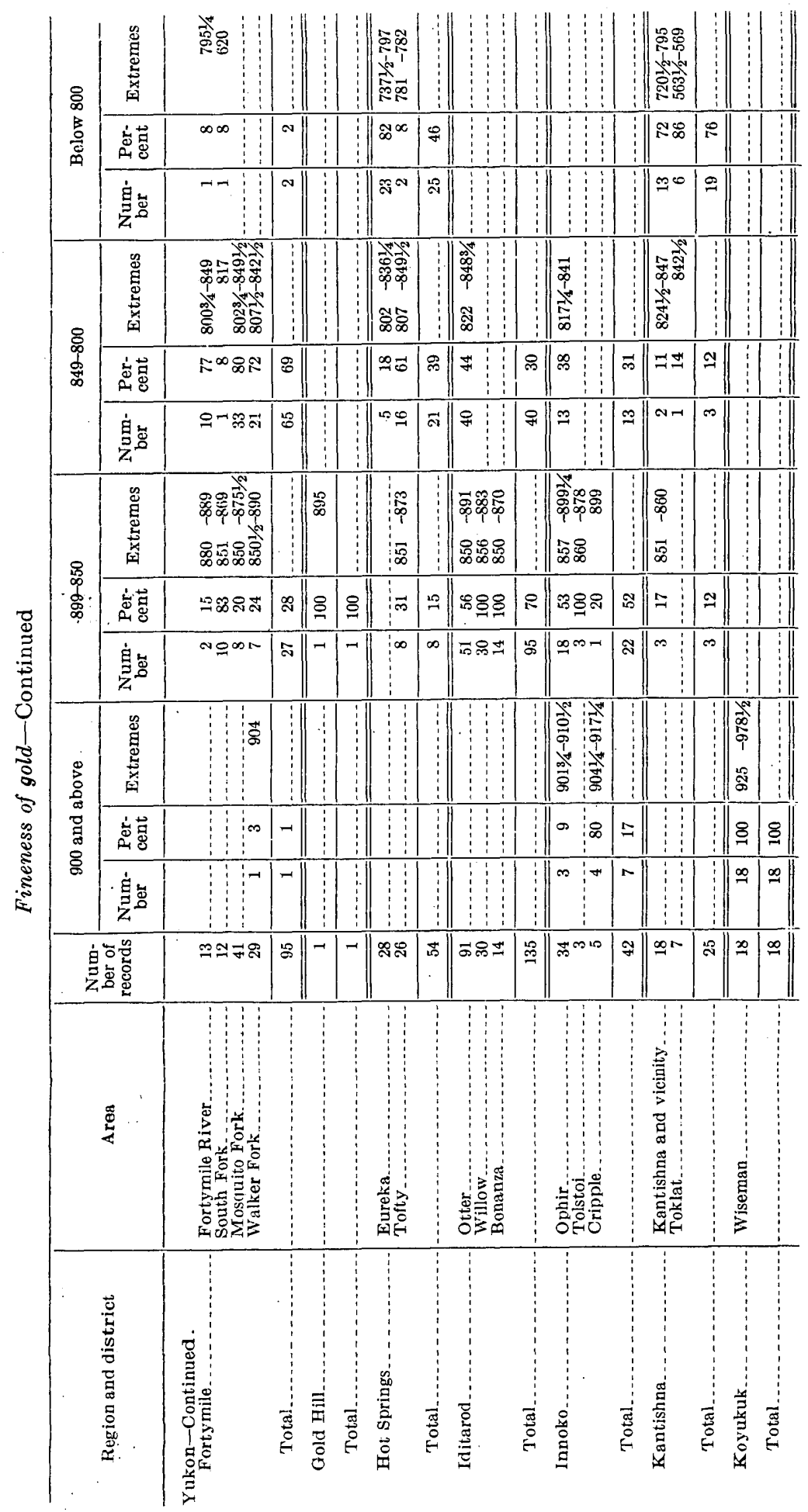




\begin{tabular}{|c|c|c|c|c|c|c|c|c|c|c|c|c|c|c|c|c|}
\hline : & \begin{tabular}{||l}
|| \\
$\vdots$ \\
$\vdots$
\end{tabular} & & & 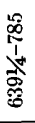 & & 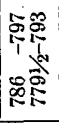 & & 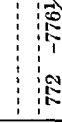 & & & 总 & & & & & \\
\hline 品 & $\infty$ & 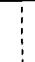 & & 8 & $\S$ & $\infty 2$ & $\cong$ & : & $\sigma$ & $\exists$ & : & ణా & & & & \\
\hline-1 & -1 & & & $n$ & $n$ & NM & is & ' & + & $\stackrel{\infty}{2}$ & $\begin{array}{l}0 \\
-9\end{array}$ & 9 & & & & \\
\hline 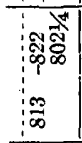 & \begin{tabular}{l|l}
$\vdots$ \\
$\vdots$ \\
$\vdots$
\end{tabular} & 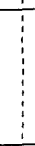 & & & & 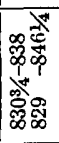 & , & & & $\begin{array}{c}\vdots \\
\vdots \\
\vdots \\
\vdots\end{array}$ & 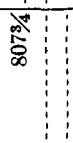 & 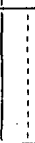 & 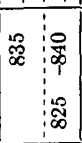 & & & \\
\hline 80 & 品 & 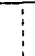 & & & & $=\infty$ & 7 & & 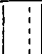 & $\vec{m}$ & $\therefore$ & ar & $\begin{array}{l:l} & 8 \\
\end{array}$ & 8 & & \\
\hline - 1 & 0 & 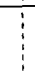 & & & & $m$ & : & & 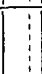 & 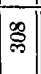 & & - & $\begin{array}{l:l}-\infty \\
\end{array}$ & $\sigma$ & & \\
\hline & $\begin{array}{l}1 \\
\vdots \\
\vdots \\
0\end{array}$ & 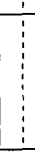 & & & & 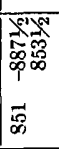 & & 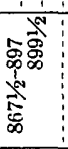 & 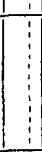 & 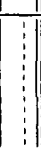 & 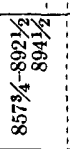 & $\begin{array}{l:} \\
\vdots \\
\vdots \\
\vdots\end{array}$ & & & 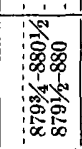 & \\
\hline$g_{]}$ & $\stackrel{\varnothing}{\circ}$ & 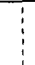 & & & & 100 & $\because$ & iso & $\infty$ & 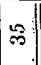 & $\stackrel{\infty}{\sim}$ & 응 & & & 요. & $11^{\circ}$ \\
\hline tr & + & 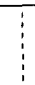 & & & & $\mathbb{N}-$ & $\mathfrak{\approx}$ & $\sigma-$ & $\infty$ & 常 & $r-$ & 10 & & & $a_{0}^{a_{0}}$ & 0 \\
\hline & & 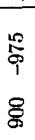 & & & & 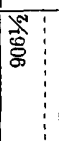 & & 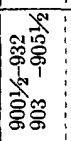 & 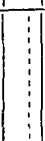 & 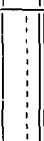 & 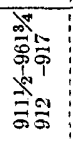 & & $\begin{array}{l}n \\
0 \\
10 \\
0\end{array}$ & & 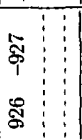 & \\
\hline & & \& & 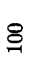 & & & $\infty$ & $\infty$ & $8 \pi$ & $\sigma$ & $\approx$ & $\overrightarrow{0}=$ & \& & : & 8 & 8 & 22 \\
\hline & & สิ & శ్ & & & -7 & - & $\mathscr{\infty} \Omega$ & \% & ฟี & $=1$ & N & ! & 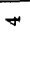 & $\begin{array}{l:}\curvearrowright \\
\vdots\end{array}$ & ? \\
\hline & $=$ & ลี & สิ & $n$ & 10 & \$̊స & क & $\mid \infty=+$ & $\cong$ & 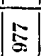 & 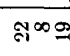 & 우 & 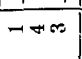 & $\infty$ & नNम & $\infty$ \\
\hline
\end{tabular}

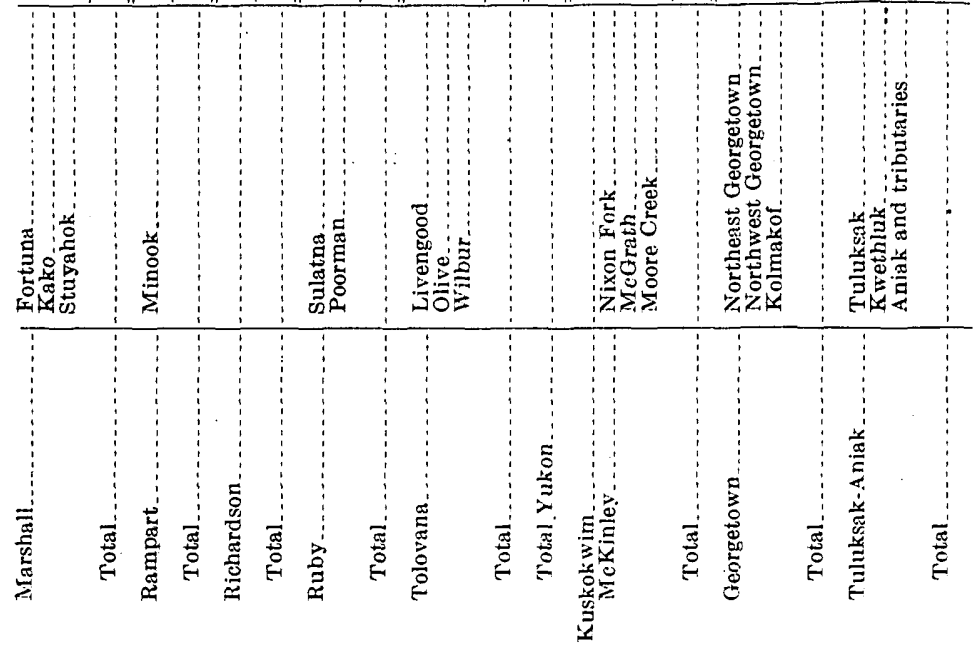




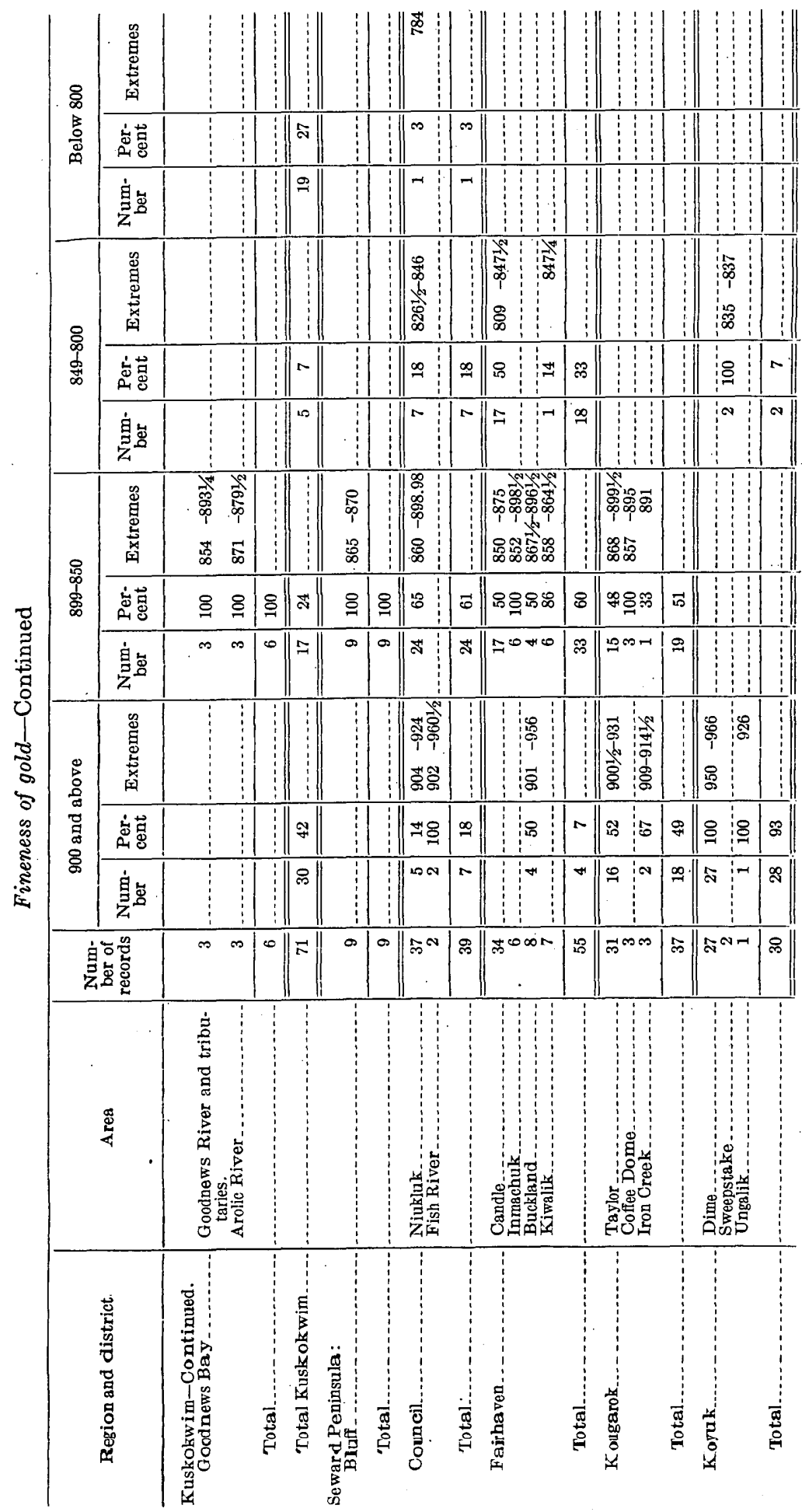




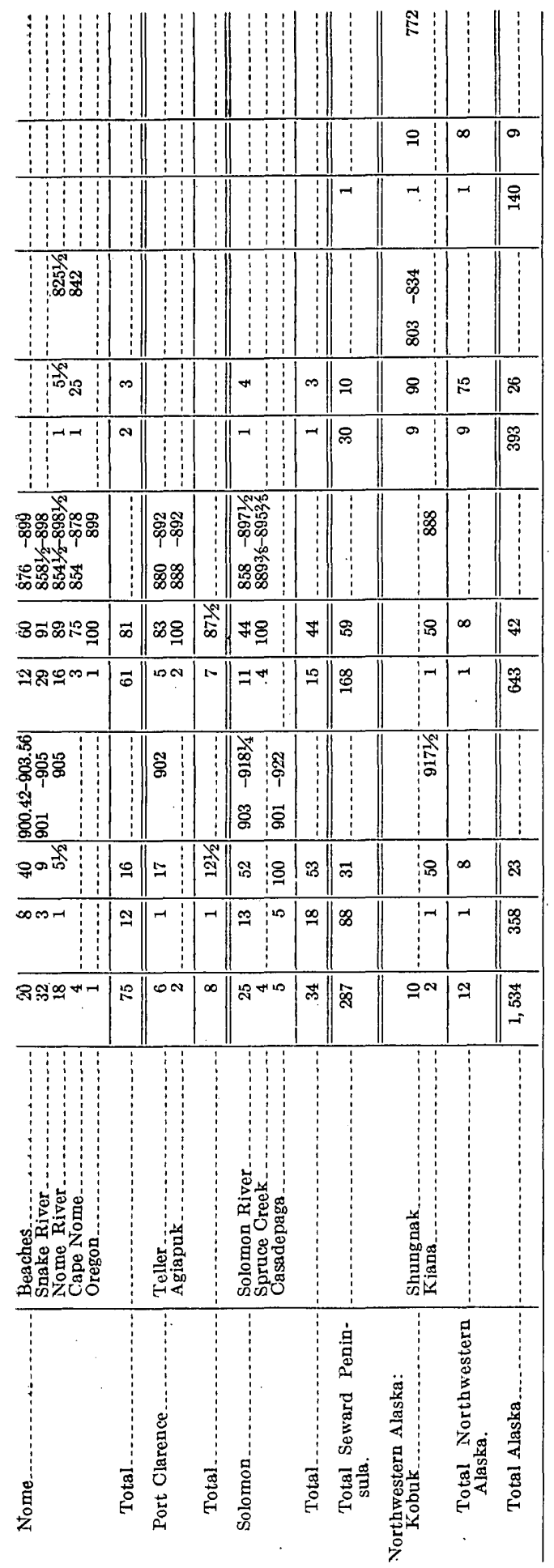




\section{DIFFERENCES IN FINENESS}

Although the records in the foregoing table set forth rather fully the available facts as to the fineness of gold in different parts of Alaska, it may be profitable to comment at this place on a few items that may not be readily apparent. The gold of the highest fineness, reported by operators to the Geological Survey from Smith Creek, in the Koyukuk district of the Yukon region, was 971 parts gold and 22 parts silver. Wimmler, ${ }^{3}$ however, refers to gold from Fay Creek, in the same district, that showed a fineness of $9781 / 2$. Certainly the upper Koyukuk area appears to be one of the Alaska districts having the purest gold, as 16 out of the 18 records available for this study showed fineness of gold from that district above 950 . In the Dime Creek area, in the Koyuk district of the Seward Penisula region, the gold is all of exceptional purity. All of the 27 records available show fineness in excess of 950 , and the highest is 966 . In the Minook area of the Rampart district of the Yukon region, Wimmler ${ }^{4}$ reports the occurrence of gold of a fineness of 975 , but the highest record received by the Geological Survey was $9451 / 2$. Of the 20 records from this district, 14 showed a fineness of 925 or higher. In the Nixon Fork area. of the McKinley district of the Kuskokwim region most of the gold is especially pure, as is shown by two records of $9613 / 4$ for gold from Hidden and Birch Creeks; of the 22 records from the area 13 are 920 or higher. On Aggie Creek, in the Fish River area of the Council district of Seward Peninsula, one small lot gold was reported that had a fineness of $9601 / 2$. A questionable record for gold on a tributary of Buckland River, in the eastern part of the Fairhaven district of Seward Peninsula, showed a fineness of 956 .

In order that the Alaska areas in which gold of high fineness is especially common may be readily recognized, those in which the preponderance of records fall into the "900 and above" category have been listed separately in the following table. In this table the percentages stated in the last column of figures indicate the percent of the records that fall into that specified category. While it is true that in the main this percentage of reports also represents roughly the relative quantity of gold of this category, it by no means should be stressed too far as representing actual fineness. For instance, in the Buckland area of the Fairhaven district, as already pointed out, one lot of gold was 956 fine, though of the eight lots from the area four were below 900 and therefore fell into an entirely different category.

\footnotetext{
3 Wimmler, N. L., Placer-mining methods and costs in Alaska: U. S. Bur. Mines Bull. 259 , p. $219,1927$.

- Wimmler, N. r., op. cit., p. 219.
} 
Alaska placer areas whose gold dominantly has a fineness of 900 or above

\begin{tabular}{|c|c|c|c|c|c|}
\hline \multirow{2}{*}{ Region } & \multirow{2}{*}{ District } & \multirow{2}{*}{ Area } & \multirow{2}{*}{$\begin{array}{l}\text { Total } \\
\text { number } \\
\text { of records } \\
\text { con- } \\
\text { sidered }\end{array}$} & \multicolumn{2}{|c|}{$\begin{array}{l}\text { Records above } 900 \\
\text { fine }\end{array}$} \\
\hline & & & & Number & Percent \\
\hline Yukon ................... & Fairbanks.......... & Nome Creek. . . . . . . . . . . . & 1 & 1 & 100 \\
\hline Do. & Koyukuk. ........ & Wiseman & 18 & 18 & 100 \\
\hline 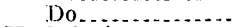 & Rampart......... & Minook................... & 20 & 20 & 100 \\
\hline Kuskokwim. .......... & Gcorgetown ...... & Northwest of Georgetown..... & 4 & 4 & 100 \\
\hline Do $\ldots$ & Tuluksak-A niak. - & Tuluksak $\ldots$ & 2 & 2 & 100 \\
\hline Seward Peninsula... & Council........... & 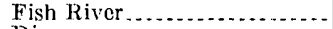 & 2 & 2 & 100 \\
\hline Do $\ldots \ldots \ldots$ & Koyuk.............. & 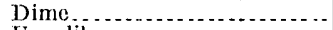 & 27 & 27 & 100 \\
\hline 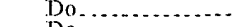 & 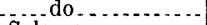 & Ungalik & 1 & 1 & 100 \\
\hline Do $\ldots \ldots$ & Solomon........... & Casadepaga. & 5 & 5 & 100 \\
\hline Yukon... & Tclovana........... & Iivengood. & 87 & 83 & 95 \\
\hline Do & $\ldots$ do $\ldots \ldots$. & Olive.......... & 11 & 10 & 91 \\
\hline Kuskokwim .......... & McKinley .......... & NeCrath $\ldots \ldots \ldots \ldots$ & 8 & 7 & 871,6 \\
\hline Y'ukon........ & Fairbanks....... & 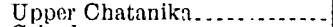 & 11 & 9 & 82 \\
\hline Do $\ldots \ldots \ldots$ & Innoko........... & Cripple $\ldots \ldots \ldots$ & 5 & 4 & 80 \\
\hline Kuskokwim........... & McKinley ....... & Nixon Fork & 22 & 17 & 77 \\
\hline Seward Peninsula.... & Kougarok....... & 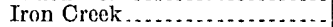 & 3 & 2 & 67 \\
\hline Copper River . . ..... & Nizina ............ & (2) & 29 & 17 & 59 \\
\hline Seward Peninsula... & Kougarok. & Taylor & 31 & 16 & 52 \\
\hline Do $\ldots$ & Solomon......... & 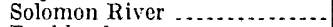 & 25 & 13 & 52 \\
\hline Do................. & Fairhaven & Buckland . . . & 8 & 4 & 50 \\
\hline Northwestern Alaska. & Kobuk. ........... & Kiana.. .1. & 2 & 1 & 50 \\
\hline 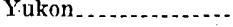 & Eagle............. & Seventymils & 38 & 18 & 47 \\
\hline
\end{tabular}

Obviously the small number of records from some of the areas raises considerable doubt as to the validity of placing the area in the designated class. For such areas additional records should be sought.

Turning from the areas that have dominantly gold of high fineness to areas having gold of the other extreme, the record indicates that in 11 areas the preponderance of records are of gold whose fineness is less than 800. The lowest fineness of gold reported in any of the records examined was that from Little Moose Creek, in the Toklat area of the Kantishna district of the Yukon region. Six assays of bullion received by the Geological Survey from this area showed gold that ranged in fineness from $5631 / 2$ to 569 and silver about 425 fine. Wimmler ${ }^{5}$ mentions some gold from this creek as having a fineness of only 550. Other districts from which gold of especially low fineness was reported are the South Fork area of the Fortymile district with 620 , the Richardson district with $6391 / 4$, the Chena-Salcha area of the Fairbanks district with $6741 / 2$, and the Hodzana area of the Chandalar district with $684 \frac{7}{10}$. All of those districts are within the Yukon region.

In order that the areas in which gold of low fineness is especially common may be readily recognized, those in which the preponderance of records of fineness fall below 800 have been listed separately in the following table:

E Wimmler, N. I., op. cit., p. 219. 
Alaska placer areas whose gold dominantly has a fineness below 800

\begin{tabular}{|c|c|c|c|c|c|}
\hline \multirow{2}{*}{ Region } & \multirow{2}{*}{ District } & \multirow{2}{*}{ Area } & \multirow{2}{*}{$\begin{array}{l}\text { Total } \\
\text { number } \\
\text { of rec- } \\
\text { ords } \\
\text { consid- } \\
\text { ered }\end{array}$} & \multicolumn{2}{|c|}{$\begin{array}{l}\text { Records below } \\
800 \text { fine }\end{array}$} \\
\hline & & & & Number & Percent \\
\hline Cook Inlet-Susitna. & Kenai... & Girdwood.. & 6 & 6 & 100 \\
\hline Do & Yentna...- & Talkeetna............... & 1 & 1 & 100 \\
\hline Yukon: .............. & Chandalar. & Hodzana... & 1 & 1 & 100 \\
\hline & Richardson. & & 7 & 7 & 100 \\
\hline Do & Tolovana ... & Wilbur & 4 & 4 & 100 \\
\hline Kuskokwim.... & McKinley..... & Moore Creek & 19 & 19 & 100 \\
\hline Yukon........ & Kantishna..... & Toklat............. & 7 & 6 & 86 \\
\hline Do... & Hot Springs. & Eureka....... & 28 & 23 & 82 \\
\hline Do.. & Kantishna... & Kantishna ............ & 18 & 13 & 72 \\
\hline Do $\ldots . . . .$. & Marshall .... & Stuyahok & 2 & 1 & 50 \\
\hline Southeastern. & Juneau_.... & (1) & 8 & 4 & 50 \\
\hline
\end{tabular}

In this table the percentages stated indicate the percent of the records that fall into this specific grade of fineness and cannot be considered as indicating, except approximately, the quantity of gold involved. Furthermore, this table includes only 85 records of low fineness, though the general table includes 142 records of low fineness. This difference is to be accounted for by the fact that in some of the areas that are not included in the short table the gold of low fineness did not form a dominant part of the output of the area. Perhaps the most noteworthy illustration of this condition is in the Crooked Creek area of the Circle district of the Yukon region, where, out of a total of 105 records, 39 showed a fineness of gold of less than 800, but as the gold of that fineness did not constitute the dominant type those records were not included in the short table.

\section{METALS OTHER THAN GOLD IN BULLION FROM ALASKA PLACERS}

So far as shown by the records that form the basis of the present study, none of the specific constituents of the bullion other than gold and silver have been determined. There has been surprisingly small variation in the records of the sum of these two constituents-995 to 990-in other words, an unaccounted-for difference of one-half to 1 percent of the total quantity of the bullion. This deficiency is probably due to the presence of copper.and iron, associated with the gold, that were not identified in the usual form of analysis and in a million ounces of bullion would probably be worth less than $\$ 100$. A few analyses, especially of the less pure dusts, show somewhat more than the usual variation in the ratio of the sum of the gold and silver to 1,000 . For most of these one is inclined to question whether the record is entirely reliable. Even these questionable records do not in general show very wide departures. For example, a few of the records of biullion from the Kantishna district, ranging from about: 
730 to 750 parts of gold, total 966 to 976 parts of gold and silver, or show an unexplained content of $21 / 2$ to $31 / 2$ percent.

In view of the almost universal truth of the generalization set forth that the sum of the gold and silver in the bullion from Alaska placers averages 990 to 995 parts in 1,000, it has been considered desirable in this report to discuss only the gold content, without tabulating separately the accessory silver. The reader, if he so desires, may readily make a computation of the amount of silver by deducting the stated fineness of the gold from this estimated sum. It is realized that this method leaves much to be desired in rigorous accuracy, but as the silver content is aside from the principal object of the present study, it is left for more adequate treatment elsewhere, and the foregoing method of reasonably close approximation may well be used for general purposes. In computing the value of the bullion, the small error that might arise through this crude method of approximating the silver is really inconsequential, as a difference of 25 parts in the silver content would usually not affect the total price more than 2 cents an ounce; and it is believed that in actual practice the error would seldom be as much as a quarter of this amount.

\section{DESCRIPTIONS OF REGIONS IN RELATION TO FINENESS OF PLACER GOLD}

The foregoing tables present in abbreviated form many of the specific facts gleaned from the reports examined, but necessarily the tables omit much information that is pertinent to an understanding of some of the geologic relations that exist in the different areas and that doubtless had an influence on the quality of the placer gold in them. All the conditions that have affected the fineness of the gold in different parts of the Territory are not yet known. In fact, the more the subject is investigated the more difficult it becomes to formulate explanations as to the relations between the fineness of the gold and the processes to which it has been subjected. For instance, it has long been held that fineness bore a somewhat close relation to the distance that the gold had been transported from its source of origin. According to this belief, the gold in its original bedrock source is usually of relatively low fineness, but as the particles are worn, in the course of their transportation from that source, and are subjected to leaching by the natural soil acids and other processes, more and more of the impurities are removed, so that the fineness increases. Whereas this explanation doubtless holds true in general, it apparently does not prevail universally, as some gold that has hardly moved at all from its source is of high fineness and other gold that has apparently traveled far from its point of origin is of low grade. 
Though it is not yet possible to determine the reasons for many of the observed differences of fineness of gold from different Alaska placers, it has seemed desirable to summarize in the following pages some of the better-established facts regarding the general geology in the various areas so far as it may have a bearing on the general problem of fineness of the placer gold. In doing this it has been necessary to pick out only a few of the items that appeared most significant from a large volume of detailed information. The reader, therefore, who desires more adequate and more complete descriptions of the different areas should consult the original reports, references to which are given at appropriate places. As will be seen, most of the references cited are to the more recent reports of the Geological Survey. While the writer takes full responsibility for the selection of the material used, he is keenly aware that his task has been mainly that of compiler who has drawn heavily on the original work of his associates in the Geological Survey for the facts he has assembled. His draft on the scientific knowledge of these associates goes far deeper than can be acknowledged by specific reference.

\section{SOUTHEASTERN ALASKA REGION}

Although in many parts of southeastern Alaska extensive mineralization resulted from the igneous intrusions that have taken place at intervals throughout a long stretch of geologic time, and although at places some of this mineralization has been competent to form lode deposits that are being commercially mined, few placers of any great significance have been formed. This is to be accounted for in part by the general topography of the region, which is unfavorable for placers, and in part by the recent glaciation, which doubtless scattered many of the small deposits that may have been formed prior to the glaciation. The relative unimportance of the placers of southeastern Alaska is perhaps best indicated by the fact that they have yielded considerably less than 1 percent of the placer output of the Territory. In spite of the small amount of placer gold that has been recovered in the region, there are three districts in which placer mining has been carried on-the Juneau, Porcupine, and Yakataga districts. The Juneau district embraces that area closely adjacent to Juneau; the Porcupine district is in the extreme northern part of the region adjacent to the international boundary, west of Skagway; and the Yakataga district embraces the coastal portion adjacent to the Pacific Ocean in the extreme northwestern part of the region. Each of these districts differs in the character and distribution of its placer deposits, and each will be described separately. 


\section{JUNEAU DISTRICT}

The Juneau district lies in the midst of the fiorded and mountainous country of the central part of the southeastem Alaska region. Its valleys are occupied by swift streams or sprawling glaciers, and the valley slopes are so steep that they offer little lodgment for placer material. Under these conditions such unconsolidated deposits as do occur are small and discontinuous. Showings of gold may be found in many of these small gravel deposits in the Juneau district, but the only valley that has contributed any considerable amount of placer gold and the only one for which records are included in the tables in this report is the Silver: Bow Basin, which lies just northeast of the town of Juneau, at the head of Gold Creek. The sedimentary rocks of the area are a complex northeastwarddipping series of schists, black slates, and volcanic rocks that are bounded on the east by granodiorite of the Coast Range intrusives. The age of the sedimentary sequence has been variously assigned, ranging from Paleozoic, according to Spencer, ${ }^{;}$to Jurassic, according to Martin. ${ }^{7}$ Although the age of the various members even yet cannot be stated with finality, the sequence as a whole is now regarded as dominantly Mesozoic. The sedimentary rocks are intruded by a number of small dikes whose composition is comparable to the Coast Range batholith, and they are intricately traversed by numerous quartz veins. These veins and the adjacent mineralized areas have been the support of the great lode-gold mining industry that has been developed in the area east and south of Juneau. Comparable veins occur in areas of sedimentary rocks of later age and of graywacke texture and composition that lie west of Juneau and were the scene of past lode mining activity all the way from Douglas and Treadwell to and beyond Berners Bay, on the north.

Eight records of the gold from the placers in the Silver Bow Basin show fineness ranging from 772 to $8273 / 4$, the mathematical average of the eight records examined being $802 \frac{1}{2}$. It is apparent that the gold is of distinctly local origin and has not been transported far or subjected long to atmospheric or other processes that might have effected much removal of the more soluble constituents of the "dust." In this connection it may be of significance to point out that the bullion received at the Seattle Assay Office in 1934 from the large gold mine that is situated near these placers contained 822 parts of gold and 148 parts of silver, with 30 parts unaccounted for in the assay. In 1935

\footnotetext{
- Spencer, A. C., The Juneau gold belt, Alaska: U. S. Geol. Survey Bull. 287, pp. 77-85, 1906 .

${ }^{7}$ Martin, G. C., Mesozoic stratigraphy of Alaska: U. S. Geol. Survey Bull. 776, p. 247, 1926.
} 
the fineness of the lode gold from the same mine, tested in the same way, gave $8201 / 2$ gold and $1481 / 4$ silver. It is distinctly surprising that this bullion from the nearby lodes had a fineness so much higher than the average of that from the placers.

\section{PORCUPINE DISTRICT}

In general, the known placers of the Porcupine district occur under geologic and topographic situations somewhat similar to those in the Juneau district. Much of the area is composed of rugged mountains that have recently been intensely glaciated and that are traversed by streams, most of the larger ones of which head in glaciers. The principal placer mining in the past has been in the northern part of the valley of Porcupine Creek and in the terraces at its mouth, which form part of the lowland of the Klehini River Valley. The sedimentary rocks are dominantly shales and limestones of late Paleozoic age, which to the north are intruded by the diorites of the great Coast Range batholith and to the south by other comparable intrusive rocks of smaller extent, which form the divide at the head of Porcupine Creek and adjacent streams. Mineralization is reported to be widespread throughout the district, though at this time no producing lode mines have been developed in the district. The gold in the placers is described by Eakin ${ }^{8}$ as usually well worn, of bright color, and ranging in texture from flour gold to nuggets weighing several ounces. According to Eakin, the distribution of the placer material is considered due largely to glacial abrasion of the country rocks of the district and later transportation by glaciers of that detritus, with subsequent resorting by the present streams. Four records of the gold from Porcupine Creek and its tributary McKinley Creek averaged about 820 fine gold, and one record from the Klehini River Valley showed $8871 / 2$ fine gold. There seems to be no reasonable doubt that most of the gold is of distinctly local origin, the gold in the larger stream. apparently having been transported the farthest.

\section{YAKATAGA DISTRICT}

The principal production of placer gold in the Yakataga district has been from the beach deposits that extend along the coast for many miles in the vicinity of Yakataga and Umbrella Reefs. Inland from the shore line a coastal plain, in part composed of old marine and fluviatile deposits, stretches northward to the steep slopes of the Robinson Mountains. The detrital material of which the coastal plain is composed doubtless contains a considerable amount of widely scattered gold, but it occurs in commercial quantities only in those

\footnotetext{
8 Eakin, H. M., The Porcupine gold placer district, Alaska: U. S. Geol. Survey Bull. 699, pp. 19-25, 1919.
} 
places where there has been subsequent reconcentration through the action of the sea or rivers. The richest placer deposits are found near the foot of the low cliffs where the waves have cut into the coastal plain. The distribution of gold along this beach is exceedingly variable, and concentrations effected during one storm may be dissipated by a succeeding one. Most of the gold is bright-colored, flaky, and in very small particles. According to Maddren ${ }^{\circ}$ flakes the size of the head of a pin are regarded as exceptionally large. The bedrock source of the gold is not known, but probably it is to be sought in the quartz veins in the unsurveyed high mountains 30 miles or more to the north of the district. The records of the eight lots of gold from this area, show an average fineness of about 895 . This high purity, as well as certain physical characteristics of the gold, indicates that the gold has undergone considerable natural refinement and suggests that it has been rehandled and transported considerable distances from its source.

\section{COPPER RIVER REGION}

As indicated by the tables, three placer districts have been distinguished in the Copper River region, though a little placer mining has been done from time to time at several other places. In point of past production, the Chistochina and Nizina districts have yielded approximately equal amounts of placer gold, and the Nelchina only little more than 1 percent of the total from the region. The Chistochina district embraces an area in the northern part of the Copper River Valley lying on the southern flanks of the Alaska Range. The Nizina district lies some 150 miles southeast of the Chistochina district in the east-central part of the Copper River region not far from the well-known copper mines near Kennicott. The Nelchina district is in the extreme western part of the Copper River region and is usually entered by way of the Matanuska Valley of the Cook Inlet region, rather than from any point in the Copper River Valley.

\section{CHISTOCHINA DISTRICT}

For purposes of this report the records from the Chistochina district have been assigned to three separate areas, namely, Slate Creek, Middle Fork, and Rainy Creek. These subdivisions are possibly unnecessarily minute, as the apparent general geologic conditions do not differ greatly in these areas and the records as to the fineness of gold in two of the areas at least are too few to be more than indicative of the probable fineness of their gold, though none of the records of fineness show marked differences in the purity of the gold.

\footnotetext{
${ }^{9}$ Maddren, A. G., Mineral deposits of the Yakatuga district, Alaska : U. S. Geol. Survey Bull. 592, pp. 134-143, 1914.
} 


\section{SLATE CREEK AREA}

Slate Creek is a tributary of the main Chistochina River from the east, joining that stream a short distance south of Chistochina Glacier. Its valley is carved in part in sandstone, tuffaceous beds, and limestones, intruded by basic dikes and-sills and in part in Paleozoic conglomerates, quartzites, and tuffs that have been intricately intruded by quartz diorite and related igneous rocks. Some infolded Tertiary beds occur in the valley of Slate Creek. The gold from Miller Gulch, one of the tributaries to Slate Creek from the north, is described as usually flat and smooth and rarely has any quartz or country rock adhering to it. Most of the gold is coarse dust and small nuggets - the largest nugget so far reported weighing about 4 ounces. Associated with the gold in the concentrates are small copper nuggets, bits of cimnabar, and more rarely fragments of the metals of the platinum group. ${ }^{20}$

\section{MIDDLE FORK AREA}

East of Slate Creek, at intervals throughout the country adjacent to the contact between the younger sandstones and tuffaceous beds of the Mankomen formation and the older conglomerates and quartzites of the Chisna formation, placer deposits have been worked at a few points in the valleys of the headwater tributaries of Chisna River, but records of the fineness of gold in those places are not now available to the writer. A short distance farther east, however, in the valley of a small tributary to the Middle Fork and lying along the same contact is a deposit whose gold is reported to have a fineness of 862 , or perhaps 10 to 20 points lower than the general run of gold from Slate Creek. Such a small difference based on a single record should not be given too much weight as representing a real difference in the gold of the two areas, for the records from Slate Creek show a range in fineness of 857 to $887 \%$. The placer deposits of the tributary of the Middle Fork, however, as described, seem to differ greatly in other respects from those of the valley of Slate Creek because the former seem to show much more glacial clay and heavy boulder wash and the workings have been mainly on bench deposits. The original source of the gold of both these areas, however, is considered identical and is attributed to areas of local metamorphism in the slates of the Mankomen formation.

RAINY CREEK AREA

The third area in the Chistochina district lies some 30 to 40 miles west of the two areas just described. It includes the placers on Rainy

\footnotetext{
${ }^{10}$ Mofft, F. H., Headwater regions of Gulkana and Susitna Rivers, Alaska: U. S. Geol. Survey Bull. 498, pp. 72-79, 1912.
} 
Creek, a small tributary of Delta River from the west, which joins that stream some 7 to 8 miles north of the the old Miller roadhouse. The eastern or lower part of the valley of Rainy Creek is dominantly carved through the high gravel and bench deposits that form such fxtensive tracts in the central part of the Copper River Valley. The bedrock of the mountains in which the stream rises is composed mainly of quartzites, tuffaceous beds, and metamorphosed limestones of Carboniferous age that have been intruded by masses of quartz diorite and hornblende diorite of Jurassic or later age. If the gold in the placer: deposits of the Rainy Creek area is the reconcentrated gold that was scattered in the widespread gravel deposits, its original source is evidently highly problematical. If, however, it is from a local bedrock source, it would appear likely to have been derived from areas that have been affected by some of the later dioritic intrusions. As already noted, the general geologic setting and the character of the gold in the Rainy Creek area have many features in common with those of the other areas in the Chistochina district described above, so that its distinction from those areas has been considered desirable more because of its remoteness from them than for any other reason.

\section{NIZINA DISTRICT}

Most of the active placer mining in the Nizina district has centered around claims in the valleys of Dan and Chititu Creeks and their tributaries. Both of these main streams flow into Nizina River, and the principal camps are 10 to 20 miles southeast of Kennicott, on the Copper River \& Northwestern Railroad. Some placer mining has also been done on Young Creek, about 4 miles south of the Chititu diggings, but no records of the fineness of gold from deposits in that valley are available at this time. The older members of the bedrock throughout much of the area drained by Young and Chititu Creeks are black and reddish shales and gray and brown sandstones, which are assigned to the Cretaceous. In the Dan Creek Valley, however, the rocks are more commonly greenstones of Permian or Triassic age, overlain by Triassic limestones and shales, known respectively as the Chitistone limestone and McCarthy shale. ${ }^{11}$ Throughout the area where mining has been in progress there are extensive deposits of bench gravels that at one time spread over the preexisting topography and seem to have been formed, in part at least, through deposition behind ice barriers resulting from the advance of the great glaciers down Chitina and Nizina Valleys. Subsequently, as new valleys were

\footnotetext{
1. Moffit, F. H., and Overbeck, R. M., The upper Chitina Valley, Alaska: U. S. Geol. Survey Bull. 675, pp. 74-78, and pl, 3, 1918. Moffit, F. H., and Capps, S. R., Geolngy and mineral resources of the Nizina district, Alaska: U. S. Geol. Survey Bull. 448. pp. 100_ 108, 1911.
} 
established, their streams cut their channels down into these deposits and effected concentration of the valuable heavy minerals they contained to make the present placers. Moffit and Capps ${ }^{11^{n}}$ were unable to determine the proportion of foreign material in the gravel deposits, but they state with certainty that the source of the placer gold was clearly the abundantly mineralized black shales. The gold from Dan Creek is said to be coarse and smooth and is accompanied in the clean-up by numerous nuggets of copper, many of which weigh several pounds, and smaller nuggets of silver or of silver mixed with copper. The gold from Chititu Creek is reported to be less worn and in smaller particles than that from Dan Creek. So far as is shown by the records considered, the average fineness of gold from the placers on Dan and Chititu Creeks is essentially identical, and the average of the 29 records of fineness from the Nizina district is almost 900 .

\section{NELCHINA DISTRICT}

The principal placer deposits in the Nelchina district are in the headwater regions of Crooked Creek and its tributaries, especially Albert Creek, some 65 miles nearly due west of Copper Center. The bedrock in the area where mining has been in progress is mainly volcanic breccia, agglomerate, and tuff of Lower Jurassic age. These are overlain by sandstone, arkose, and sandy shale, which are of Middle Jurassic age and are members of the so-called Tuxedni sandstone formation. Tertiary lavas cap some of the highlands at the head of Albert Creek, and acidic dikes have been found in the general area. As shown in the table (p. 156) the gold from this district ranges in fineness from about 812 to 819 and has an average fineness of about 815. According to Chapin, ${ }^{12}$ the gold is widespread, but it is rarely concentrated enough to be recovered profitably. Chapin believed that the widespread gravel deposits are mainly of glacial origin and that they therefore had been little sorted until reworked by present streams. Although the gold in these deposits may have been originally derived from a remote and now unknown source its slight transportation except by glaciers from that site may in part explain why it has such a low fineness.

\section{COOK INLET-SUSITNA. REGION}

The extensive area in central Alaska stretching from Cook Inlet on the south, along that water body, and northward along Susitna River, to the Alaska Range has long been known as the Cook InletSusitna region. In this vast tract of country are four principal dis-

\footnotetext{
מn Momt, Ir. Ir., and Cappe, s. R., op. sit., pp. no-10o.

${ }^{12}$ Chapin, Theodore, The Nelchina-Susitma region, Alaska: U. S. Geol. Survey Bull. 668, pp. 59-64, 1918.
} 
tricts in which placer mining has been most active. Named successively from south to north, they are the Kenai, Girdwood, Yentna, and Valdez Creek districts. To date these districts have yielded placer gold to the value of more than $\$ 6,000,000$. In order of the magnitude of their output the districts stand as follows: Yentna, Kenai, Valdez Creek, Girdwood. Still smaller amounts of placer gold have been afforded by other camps in the region, as for instance, at Willow Creek, near Wasilla, but as no record of their gold has been available for consideration in the present study they will not be discussed in this report.

\section{KENAI DISTRICT}

\section{SUNRISE AND HOPE AREAS}

The discovery of placer gold in the Kenai Peninsula dates back to 1848. This placer gold was the first recorded recognition of gold at any place in Alaska. The principal productive placer-mining camps have centered more or less closely around the towns of Sunrise and Hope and in the valleys of the streams that flow northward and empty into Turnagain Arm near those two towns. So far as is shown by the fineness of gold from the two areas or by the general geologic environment the separation of the two is hardly warranted, but inasmuch as they are rather distinct geographically it was felt that there was some advantage in keeping the records of the two areas distinct. The bedrock in both the Hope and Sunrise areas consists of a monotonous sequence of graywacke and slates in which identifiable key horizons are lacking. These rocks, which are presumably in part at least of late Mesozoic age, have been highly folded and faulted. Here and there these sedimentary rocks are cut by fine-grained feldspathic dikes, many of which are traced for considerable distances though they are very narrow. Many indications of mineralization have been found in the district, and some of the properties in the past have afforded significant amounts of lode gold. Tuck ${ }^{13}$ and the other geologists who are most familiar with the area have little hesitation in assigning the source of the gold found in the placers, in both the Hope and the Sunrise areas, to the disintegration and erosion of the small quartz stringers that occur in such numbers throughout the bedrock of those areas. Practically all the lowland tracts in both these areas have been covered by glacial ice in the relatively recent past, so that it is doubtful whether any of the placer deposits formed before glaciation have been preserved, and the existing placers seem to mark reconcentration of the glacial deposits or material that has been eroded or deposited since that time. These conditions may afford a partial explanation of the

13 Tuck, Ralph, The Moose Pass-Hope district, Kenai Peninsula, Alaska: U. S. Geol. Surrey Bull. 849-I, pp. 521-527, 1938.

$252006-41-3$ 
rather low fineness of the placer gold in each of these areas, which, as shown by the table (p. 156), for the Sunrise area ranged between $8271 / 4$ and 856 and averaged $8361 / 2$ and for the Hope area ranged between $8171 / 4$ and $8261 / 2$ and averaged 821 .

\section{WEST COAST AREA}

Unlike the creek and bench placers that occur in the Sunrise and Hope areas of the Kenai district, at places on the west shore of Kenai Peninsula or along the east shore of Cook Inlet a small amount of concentration has been effected by the waters of Cook Inlet that has resulted in the formation of beach placers. Records of two lots of gold from a locality near the mouth of Kenai River show a range in fineness of 839 to 853 and an average of about 846 . At present these deposits are of little commercial importance. They clearly have been formed by the reconcentration through beach action of the glaciofluviatile deposits that form a wide lowland stretching from the coast to the foothills. It seems likely that the gold may have originally been derived from somewhat the same sources as those in the. Sunrise and Hope areas, but because the material was transported farther and was subjected to more active erosive processes, the gold acquired its greater purity.

\section{GIRDWOOD DISTRICT}

The Girdwood district is a small placer camp north of Turnagain Arm. Practically the only deposits that have been productive in the past lie in the valley of Crow Creek, a side stream that enters Glacier Creek about 3 miles from Turnagain Arm. The bedrock of the district is in general identical with that in the Hope and Sunrise areas, a short distance to the south. It consists of graywacke and shale, some of which is of Upper Cretaceous age. Most of the particles of gold range in size from medium to coarse grains, but small nuggets are fairly common. The whole district has been severely glaciated in the past, and even now glaciers are found at the heads of many of the gulches tributary to Crow Creek or its side streams. Several retreats and advances of the glaciers can be recognized from the character of the gravel deposits in the valley, and an interesting and complicated rearrangement of drainage lines is shown by the buried channels disclosed by the mining operations. Numerous acidic igneous rocks form dikes, sills, and pipes, cutting the sedimentary rocks, and mineralization in the form of quartz veins and stringers is common. The source of the gold in the placer deposits is apparently very local, and transportation by fluviatile processes has been relatively slight. The fineness of the gold as shown by the records given in the table seems to accord well with this determination because the gold is of very low grade, averaging only about 730 fine. 


\section{YENTNA DISTRICT}

Lying west of Susitna River and embracing the southeastern slopes of the foothills of the Alaska Range from Yentna River northeastward is a tract in which extensive placer deposits support a considerable mining industry. In general, the larger features throughout this entire district are similar, but for the purposes of this report the district has been subdivided into two main areas, which have been called the Cache Creek and the Peters Creek areas. An area more remote and less significant in placer production lying east of Susitna River has been designated the Talkeetna area. Another area that. has had some placer production centers around Fairview Mountain and lies some 15 to 20 miles southwest of the Cache Creek area. Inasmuch, however, as no adequate records of the fineness of its gold are available, this area will not be discussed further in this report.

\section{PETERS CREEK AND CACHE CREEK AREAS}

Both Peters Creek and Cache Creek are tributaries of Kahiltna River, which, in turn, is a tributary of Yentna River. The two creeks: rise in more or less the same highlands. Peters Creek has its source in the Dutch Hills and flows generally southeastward until reaching the broad lowlands of the Susitna, where it turns abruptly to the south or slightly west of south to its junction with Kahiltna River. Cache Creek with its tributaries, on the other hand, flows more or less southward and westward and joins the Kahiltna about 15 miles upstream from the mouth of Peters Creek. Also rising in the Dutch Hills and tributary to Granite Creek, which joins Kahiltna River about 5 miles above Cache Creek, are other streams on which productive placers have been found. The largest of these tributaries of Granite Creek is Dutch Creek, and records of the fineness of its gold have been included with those of the other streams in the so-called Cache Creek area.

The oldest of the sedimentary rocks is a complex of graywacke, sandstone, and shale that seems to have been formed in the Mesozoic and probably in the later part of that era. These rocks form most of the higher areas, such as the Dutch Hills and Peters Hills. These rocks, near the high mountains of the Alaska Range, have been intruded by diorites, granites, and associated rocks. Lying across the beveled edges of the older formations and now occupying much of the lower areas are conglomerates and coal-bearing sediments of Tertiary age. Since these rocks were laid down, all of the region has been intensely glaciated, and even now large glaciers may be found at the heads of practically all the main streams that rise in the Alaska Range. It seems certain that the gold of the placers originated in the quartz veins and stringers that are common in the Mesozoic slates. Such. material as had been disintegrated prior to the formation of the coalbearing rocks, was doubtless reworked by the streams of that epoch. 
Capps ${ }^{14}$ has described a Tertiary surface and placer concentration of that age in the district. Subsequent disintegration and weathering of the rocks of all ages was followed by further re-sorting and erosion by the glaciers, so that except in protected spots many of the preexisting concentrations were dissipated. The present-day placers are, therefore, in large measure due to erosion and reconcentration of materials prepared by earlier processes. In spite of this rather complex history, it is remarkable that, according to Capps, most of the gold is coarse, and though somewhat worn some of the pieces show crystalline outlines and adhering pieces of the vein material from which they were derived. The rather high fineness of this gold and the remarkable uniformity of the records from all parts of the area seem somewhat out of line with such a history. For instance, the variation in the 63 records from the Cache Creek area is only 27 points, or from $8503 / 4$ to $8773 / 4$; and of the 18 records from the Peters Creek area, all but one showed a similar range of fineness, that is, from $8541 / 4$ to 880 . In order that the records of fineness of the gold from the individual creeks in the Cache Creek and Peters Creek areas may be set out in more detail, the following tables have been prepared.

Fineness of placer gold from Cache Creek area, Yentna district, of Cooli InletSusitna region

\begin{tabular}{|c|c|c|c|}
\hline Creek & $\begin{array}{l}\text { Number } \\
\text { of records }\end{array}$ & $\begin{array}{l}\text { Range of } \\
\text { flneness }\end{array}$ & $\begin{array}{l}\text { Average } \\
\text { fineness }\end{array}$ \\
\hline $\begin{array}{l}\text { Cache. } \\
\text { Dollar. } \\
\text { Falls } \\
\text { Thunder. } \\
\text { Short } \\
\text { Nugget. } \\
\text { Gold } \\
\text { Chechako Guich } \\
\text { First and Dutch }\end{array}$ & $\begin{array}{r}34 \\
8 \\
3 \\
7 \\
2 \\
5 \\
1 \\
1 \\
2\end{array}$ & 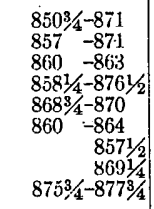 & $\begin{array}{l}866 \\
865 \\
861 \\
865 \\
869 \\
861 \\
857 \\
869 \\
876\end{array}$ \\
\hline Total & 63 & ...... & 865 \\
\hline
\end{tabular}

Fineness of placer gold from Peters Creek area, Yentna district, of Cool InletSusitna region

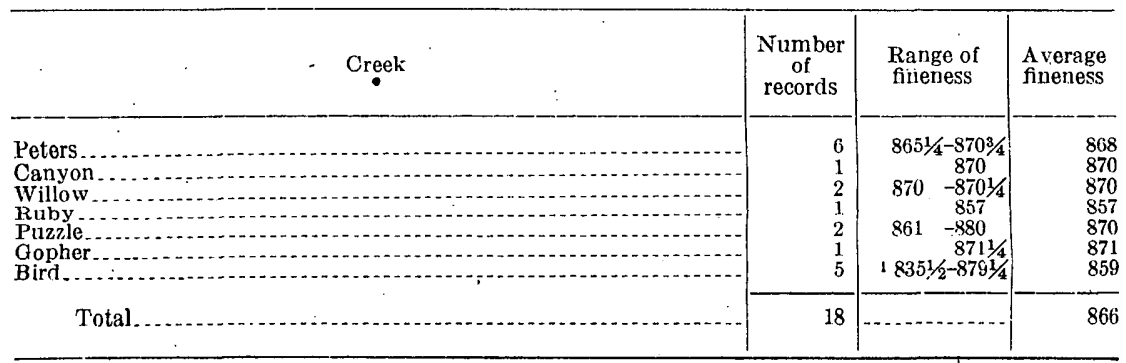

1 Only one record below 854 .

${ }_{14}$ Cupps, S. R., An early Tertiary placer deposit in the Yentna district, Alaska: U. S. Geol. Survey Bull. 773, pp. 53-61, 1925; The Yentna district, Alaskal: U. S. Geol. Survey Bull. 534, pp. 47-72, 1913. The determination of the age of certain of the older rocks as set forth in Capps' report has been modified as a result of later studies in adjacent arcas. so that rocks which in Bulletin 534 were called "Paleozoic or Mesozoic" are now regarded as exclusively of Meso\%oic age. 
As already noted, an area called in this report the Talkeetna area has been set up to embrace a small placer tract east of Susitna River. Only one record of fineness of the placer gold from this tract is available and the report is regarded as none too reliable. It pertains to a single small lot of gold from Fish Creek. Some doubt as to its accuracy arises through the low total of the parts of gold and silver, which is only 966 (gold 759 and silver 207). As this report is so greatly at variance with records from other Yentna areas and the tract lies at such a distance from those areas, it seemed to represent gold of such entirely different character as to justify listing it separately.

\section{VALDEZ CREEK DISTRICT}

The Valdez Creek district lies near the head of Susitna River, about 60 miles in an air line east of the station of Cantwell, on the Alaska Railroad. The bedrock of the district in the vicinity of the placers is predominantly argillite, which Ross ${ }^{1.5}$ considers to be Triassic in age. North of Valdez Creek are extensive tracts of schists that are regarded as somewhat younger than the argillite. Both these sedimentary members are intruded by diorite of Upper. Jurassic age or younger. There are innumerable quartz veins in the argillites and some zones of sheared and mineralized country rock, some of which have appeared worthy of exploitation as lode deposits. The whole district has been extensively glaciated in the relatively recent geologic past, which effected considerable modification of the earlier topography and deposits. Some of the placer deposits there represent the filling of old channels, others the reworked glacial and glaciofluviatile deposits that were spread over the country, and still others are the result of erosion of the bedrock of these valleys by the present streams. The gold from these deposits of different types shows considerable difference. Ross describes some gold from creek claims as flat and well worn, but some was rough and showed little evidence of wear. That which came downstream from one of the old buried channels was smoother and less worn than that from above this channel. All the records of fineness of gold from this district, with a single exception, show with remarkable uniformity a fineness of about 852. The single exception came from a small gulch where the gold may be relatively near its bedrock source. This lot of gold had a fineness of 828 , which seems rather high for gold that has not; been transported far from its point of origin, though it is about 24 points below the average of the other placer gold from the district.

15 Ross, C. E., The Valitez Creek mining district, Aluska: U. S. Geol. Survey Isull. 849-H., pp. 444-455, $19: 3$. 


\section{SOUTHWESTERN ALASKA REGION}

Practically the only area within the whole Southwestern Alaska region where placer gold has been mined commercially is on Kodiak Island. In the main, this is not due to accidental conditions but results from the fact that throughout most of that region mineralized deposits from which productive placers might be accumulated are practically absent. This condition, however, does not hold true for Kodiak, as mineralization is by no means uncommon in the Mesozoic sediments that make up most of the bedrock of the island. ${ }^{16}$ These sedimentary rocks have been intruded at a number of places by deepseated igneous rocks of the granite family. The absence of extensive placers on Kodiak Island is to be attributed in general to the ruggedness of the country, due to recent glaciation, and the scarcity of places where the detrital material worn from the mountains can find lodgment within reach of miners. As a result, practically all the placer deposits that have been mined are beach deposits. Of the nine records attributed to Kodiak in the table on page 157, all but one are of gold from beaches along the southwestern coast of the island. The extremes of the eight reports are $8241 / 4$ and 850 , and the average is 837. The excepted record pertained to gold from a small ravine known as Lone Pine Gulch, and its gold was reported to be 882 fine. According to these records the beach gold from Kodiak, as compared in fineness with that from the Yakataga, which has already been discussed, and with that from the Nome beaches, which will be described later, shows a much lower average run than either. It is perhaps more nearly comparable with the beach gold reported from the area on the west coast of the Kenai district of the Cook InletSusitna region. The low fineness suggests the absence of long-continued weathering action and slight transportation of the gold from its point of origin. As with so many of the Alaska areas that embrace considerable tracts of mountainous country, practically the whole of Kodiak Island has been covered by glacial ice in the recent geologic past, and many of its present features were derived largely from the events that were part of that occupation or have been impressed subsequently on the topography that resulted therefrom, so that its placers are doubtless of very recent origin.

\section{YUKON REGION}

The Yukon region of Alaska, a great tract of country more than 800 miles long from east to west and in places 500 miles wide from north to south, embraces the major portion of interior Alaska. It extends

${ }^{10}$ Capps, .S. R., Kodiak and adjacent islands, Alaska: U. S. Geol. Survey Bull. 880-C, pp. $171-173,1937$. 
from the international boundary to Bering Sea and from the summit of the. Alaska Range to the summit of the Brooks Range. It thus embraces a great variety of geographic and topographic features and in different parts contains numerous placer-mining camps, some of which are among the largest producers of gold in the Territory. For convenience this vast region has been subdivided into a dozen or more smaller tracts called districts, and many of these have been still further subdivided. Most of these districts differ so greatly from one another in their physical and economic conditions that it is impracticable to find many points in common that can be briefly summarized. It has, therefore, been considered undesirable to attempt a description of the region as a whole. Some of the more pertinent facts are given, however, under the descriptions of the individual districts. The arrangement that has been adopted for describing the districts is purely alphabetical and was determined by the name of the district. This necessarily results in considerable skipping about that might have been somewhat lessened by the use of some geographic order, but as the districts are geographically isolated no geographic system would have proved much better and would have caused confusion of other types.

\section{BONNIFIELD DISTRICT}

The Bonnifield district is considered to include the placer area on the northern flanks of the Alaska Range, lying east of Nenana River and west of Delta River. Its streams are either tributaries of the rivers named or flow northward, traversing the lowland of the Tanana River and ultimately joining that stream. The bedrock in most of the area where the placers occur is dominantly highly metamorphic schist. Some of the schists are definitely correlated with the old pre-Cambrian rocks called the Birch Creek schist, but other schists seem to be younger and may even be of Paleozoic age. The older schists are mostly derived through the metamorphism of sedimentary rocks, but the younger schists, which have been called the Totatlanika schist, are mainly altered effusive igneous rocks that presumably had a rhyolitic composition. At a number of places both of these schist formations have been intruded by deep-seated intrusive rocks of dioritic or granitic composition that are regarded as not older than the Jurassic. Forming scattered patches throughout the district and an extensive tract in the adjacent country to the south are Tertiary sediments with which are associated numerous coal beds. Masking much of the country north of the higher hills are broad deposits of loosely consolidated gravels, called the Nenana gravel, of still later Tertiary age.

The known placer deposits of the district may be grouped into four more or less distinct areas that have the names of the principal streams to which they are tributary and are from west to east the 
Totatlanika area, the Tatlanika area, the Wood River area, and the Little Delta area.

\section{TOTATLANIKA AREA}

The principal placers in the Totatlanika area are in the head water tributaries of the main stream, especially on Platte and Marguerite Creeks, which rise in or near the granitic masses of Jumbo Dome and the unnamed hills to the east. The records examined of the gold recovered on both of these creeks show a fineness of about 850 , the range of the seven records available being from 839 to 858 . One record from Eva Creek, a tributary of California Creek, shows gold 9001/2 fine. The geologic environment of Eva Creek seems to be different from that of the other creeks named in that it does not derive its deposits dominantly from an area in which granitic rocks are exposed. This may account for the difference in the composition of the gold. It should be noted, however, that considerable mineralization has been recognized in the rocks of the Eva Creek Valley; in fact, at one time lode mining was in progress near the head of that stream on a lode carrying basic sulphides and some gold. There is also local mineralization of the country rock of the California Creek Valley near the mouth of Eva Creek, and several attempts have been made to develop silver-lead lode deposits there. Possibly the explaniltion of the high fineness of the gold in the sample from Eva Creek that was recorded is that it had been carried a considerable distance from its source which may have been veins near some granitic area such as that near Jumbo Dome.

The gold of the Totatlanika area is described by Capps ${ }^{17}$ as being in general rather well worn and in moderately small particles. Orı the streams near the granite area; such as Platte and Homestake Creeks, much of the gold is rusty and rather coarse. From the available descriptions it would seem that the gold of the placers was deriverl from rather nearby sources. Capps, however, who is familiar with the field evidence, suggests that it probably went through at least an intermediate stage of deposition in the high gravels and was subsequently reconcentrated from them.

TATLANIKA AREA

The Tatlanika area lies some 10 miles or more east of the Totatlanika area. The principal placers that have been mined are in the valleys of Moose and Grubstake Creeks. The geology of the area has much in common with that of the Totatlanika area, though no granitic rocks are known to be exposed and the general area is more thickly mantled by the deposits of Nenana gravel of Tertiary age.

${ }^{17}$ Capps, S. R., The Bonnifield region, Alaska: U. S. Geol. Survey Bull, 501, pp. 43-47, 1912 
All of the six records of the fineness of gold from Grubstake Creek show a fineness of about 834, ranging as they do from 832 to 836 . The single record available of gold from the placers of Moose Creek shows a fineness for that gold of 877 , which seems anomalous, as gold from those placers would appear to have been derived from more local sources and to have undergone less transportation than that: from Grubstake Creek. The gold from the placers on Grubstake Creek, according to Capps, ${ }^{18}$ is flat, well-worn, and in rather small pieces, lying on a bedrock that is dominantly soft clay, sand, or coal.

\section{WOOD RIVER AREA}

About 5 miles east of the placers of the Tatlanika area are several placer camps on Gold King Creek, a tributary of Wood River. The geology in the vicinity of these placers is in the main similar to that in the vicinity of the placers in the area to the west, except that outcrops of the Tertiary coal-bearing rocks are nowhere near as extensive. The fineness of the gold from the two areas is almost identical, as is shown by the fact that the seven records of gold from Gold King Creek average about 833 fine and range between 8311/4. and $8351 / 4$. The gold from the placers on Gold King Creek is described by Capps as flat, well-worn, and in small particles lying on a soft clay bedrock. According to Capps ${ }^{19}$ the gold in the richer ground has been in large part reconcentrated from the more scattered gold that, occurs in the widespread Nenana gravel deposits that cover most of the area.

\section{IITTLE DELTA AREA}

Some 30 miles east of the placers of the Wood River area is another small tract in which placer mining has been in progress. The only placer in this eastern area for which records of the fineness of the gold are available is in the valley of Portage Creek, which flows eastward to join the West Fork, itself a tributary of Little Delta River. The general geologic setting of the placers in the valley of Portage Creek is comparable with that in the valley of Gold King Creek, in the Wood River area. There is this difference, however, that while Portage Creek itself is mainly cut into deposits of Nenana gravel, these loosely consolidated rocks give place a few miles to the south of Portage Creek to the typical Birch Creek schist. Some 5 miles south of the contact of the Nenana gravel and the schists are extensive exposures of granitic rocks that form the highland of much of the area in which the headwater streams of West Fork of Little Delta River rise. As a result, much of the material forming the Nenana gravel in the vicinity of Portage Creek must have come from

3.8 Capps, S. R., op. cit., pp. 47-49.

${ }^{10}$ Capps, S. R., op. cit., pp. $49-51$. 
this general source. The gold of the deposits on Portage Creek seems closely comparable to that from the areas farther west. According to the two records available, its fineness is about 830. Capps ${ }^{20}$ has described several other creeks in this same general area from which some placer gold has been recovered, but specific records of its fineness are not available though general information indicates that it was comparable to that of the gold from Portage Creek.

\section{Chandalar district}

Embracing a large tract of country on the southern flanks of the Brooks Range, which forms part of the watershed of the Yukon River Valley, is a rather ill-defined district, which, taking its name from the principal stream that traverses it, is called the Chandalar district. This district is difficult of access and is one of the least-known parts of Alaska. The principal area in which commercial placers have been developed centers around the streams that radiate from the highlands some 10 miles east of Chandalar Lake. Of these streams, Big Squaw and Little Squaw Creeks flow northward into the lowland containing lakes, part of which drain eastward into Grave Creek and thence into the Middle Fork of the Chandalar, but the larger part of which drains westward by way of Lake Creek into North Fork of Chandalar River. Rising a short distance south of the head of Little Squaw Creek and trending first southward and later southwestward and even westward is Big Creek, also a tributary of the North Fork. Rising near the head of Big Squaw Creek and having a general southwesterly and westerly course is Tobin Creek, which discharges into Chandalar Lake. These scattered placers have in general comparable features and so for convenience have been grouped together and are discussed under the somewhat inexact title of North Fork area.

Remote from this North Fork area and showing many features dissimilar from those of that area is a tract that has been designated as the Hodzana area, from the principal stream that traverses it. Hodzana River is a tributary of the Yukon from the northwest that joins that stream some 40 miles southwest of the mouth of Chandalar River and traverses a country of low relief that is practically unexplored. It rises in the highlands that form the divide betwieen tributaries of the Koyukuk and Chandalar Rivers.

\section{NORTH FORK AREA}

The general bedrock in the vicinity of the placer workings in the North Fork area consists of early Paleozoic phyllites, schists, limestones, and some undifferentiated greenstone and gneiss. Some 10 to 15 miles northeast of the mines is a small area of intrusive granitic

${ }^{20}$ Capps, S. R., op. cit., pp. 51-52. 
rocks, and about the same distance to the north and west is a large area of similar igneous rocks. A long time after the deposition and injection of these rocks the region was extensively glaciated, and the various incidents that accompanied and resulted from the advance and recession of the ice produced significant changes in the courses of the streams and in the detritus that was spread widely over the country even outside the areas that were actually occupied by the ice. As a result some of the placer deposits occupy old abandoned beds of streams that antedate the coming of the ice; others are the reconcentrated deposits that were formed subsequent to the ice invasion. For instance, Mertie ${ }^{21}$ describes an occurrence on Little Squaw Creek where the pay streak left bedrock and continued out over the glacial deposits, which thus acted as a false bedrock. Most of the mining in this area is by means of drifting, as the depth to bedrock in places is as much as 100 feet. Mertie states that the origin of the gold in the placers is to be attributed to the numerous quartz veins that have been found in the basins of all the creeks that contain placers. Some of these veins are well enough defined to have been staked for lodes, and some activity has been shown in their development. The origin of the veins, however, has by no means been demonstrated.

According to the 17 available records, the gold of the North Fork area has an average fineness of about 848 . There is relatively slight deviation from this average, the extremes recorded being $8353 / 4$ and 854 , with only one record below 840 and three above 850 . These records do not differentiate between the gold from the older deposits and that from the younger ones. Mertie, however, states that the gold in the preglacial channel is somewhat darker, coarser, and more water worn than that from the younger gravels. He also states that nuggets worth as much as $\$ 180$ at the old price of gold have been found in the preglacial deposits but that none worth more than $\$ 10$ have been found in the deposits that lie above the glacial till.

HODZANA AREA

As has been stated, little mining or geologic work has been done in the valley of Hodzana River, and therefore little definite information is available as to the conditions that prevail there. One small lot of placer gold from that valley, however, has been reported by Mertie to have a fineness of $6847 \%$, which differs so greatly from any gold reported from anywhere within hundreds of miles of this district that its uniqueness warrants special mention. This determination is open to some question inasmuch as the sum of the gold and silver is only 958 , which is far below the sum shown by practically all the other analyses considered in this study.

a1 Mertie, J. B., Jr., Geology and gold placers of the Chandalar district, Alask $:$ U. $\mathbf{\text { S. }}$ Geol. Survey Bull. 773, pp. 254-263, 1925. 


\section{CHISANA DISTRICT}

The Chisana district, as that term is used in this report, is bounded on the east by the international boundary, on the west by Chisana River, on the north by the Nutzotin Mountains, and on the south by the White River and the highlands forming the northern slopes of Mount Natazhat and adjacent mountains. Practically the only placer deposits that so far have proved profitable to mine are closely restricted to the streams tributary to Chisana River from the east, near the small settlements of Chisana and Bonanza. The principal streams on which mining has been done are Chathenda (or Johnson) Creek and Chavolda (or Wilson) Creek. A strong eastward-trending fault crosses the country between these two creeks and brings the Mesozoic shales, graywackes, and conglomerates into contact with the lava flows, tuffs, and agglomerates that are presumably mainly of Carboniferous age and are associated with some shales and limestones that are Devonian. The Paleozoic rocks have been intruded by granitic intrusive rocks that are mainly diorite and diorite porphyry. Forming isolated small patches overlying both the Paleozoic rocks and the intrusive rocks are conglomerates, shales, and sandstones of Tertiary age. According to Capps ${ }^{22}$ all the productive placers lie within a radius of 5 miles of Gold Hill, which is capped by Tertiary gravels that lie on the nearly vertical contact of the Paleozoic rocks and the intrusive rocks. He believes that the present placers have resulted from reconcentration of materials from former extensive gravels similar to those now found on Gold Hill and that the original source of the gold was the gold veins in the Carboniferous rocks. He describes the gold from Bonanza, Little Eldorado, and Skookum Creeks and in the valley of Glacier Creek as smooth and worn as though subjected to considerable handling by streams. The gold from Big Eldorado Creek, on the other hand, is bright, sharp, and angular, and shows almost no evidence of stream wear. Curiously the gold from Big Eldorado Creek, according to the records available, is considerably finer than that from the other localities. The two records from Big Eldorado show a fineness of $8651 / 2$ and $8663 / 4$, whereas records from Bonanza and Little Eldorado show each approximately 810, and one from Gold Run 8523/4. Four other records from this area whose specific source is not known show a range in fineness from $7973 / 4$ to 848 and average 823 .

\section{CIRCLE DISTRICT}

The Circle district takes its name from the town of Circle, on the Yukon, but the principal placer camps are 30 to 40 miles southwest

${ }_{22}$ Capps, S. R., The Chisana-White River district, Alaska: U. S. Geol. Survey Bull. 630; pp. $92-118,1916$. 
and some 40 miles southeast of that settlement. 'The two areas to the southwest of Circle are here called respectively the Crooked Creek area and the Birch Creek area above Crooked Creek. The area to the southeast of circle has been designated the Woodchopper-Coal Creek area.

The camps to the southwest are all more or less closely distributed around a center formed by Mastodon Dome and the ridges extending from it. The great number of records available from camps in this southwestern area which are of wide geographic distribution and show a great range in fineness of gold, has given rise to considerable difficulty in making subdivisions large enough to have general significance and yet small enough to differentiate unlike areas. In the table on page 157 three main areas of the Circle district have been distinguished. It is realized that this small number prevents adequate setting forth of much of the information that might be significant. To remedy that. defect in some measure, it is proposed to discuss some of the records: from the individual creeks in each area in somewhat more detail than has been customary in the preceding descriptions. As the relations of the different creeks to each other are rather complex, a small index sketch (fig. 7) is given, on which the positions of principal creeks that are tributary to Birch Creek are indicated.

\section{CROOKED CREEK AREA}

The dominant bedrock throughout the area adjacent to Crooked Creek and its tributaries is Birch Creek schist of pre-Paleozoic age. These schists exhibit numerous lithologic phases, but in the main they are highly metamorphosed sediments that are now quartzites, quartzite schists, quartz-mica schists, feldspathic and chloritic schists, and lesser amount of carbonaceous and calcareous schists and crystalline limestone. In places, as for instance in the valleys of Mammoth, Deadwood, Hot Springs, and Portage Creeks, these schists have been intruded by granitic and quartz dioritic igneous rocks that are regarded as of Mesozoic age. The geologic events that have taken place in the area in the Tertiary and later epochs have by no means been thoroughly worked out, but except in small local areas no indications have been found that any part of the area has undergone extensive modification through glaciation. Placers of many different types have been recognized, ranging from old stream placers, some of which are now deeply buried and others of which now stand as benches at considerable elevations above the present streams, to recent concentrations produced by the modern streams or that mark small hillside cleposits resulting from the weathering that is in process. So far as shown by the evidence available, all the placer material is distinctly of local origin and has not been. transported far outside the basin of the stream in which it originated. 


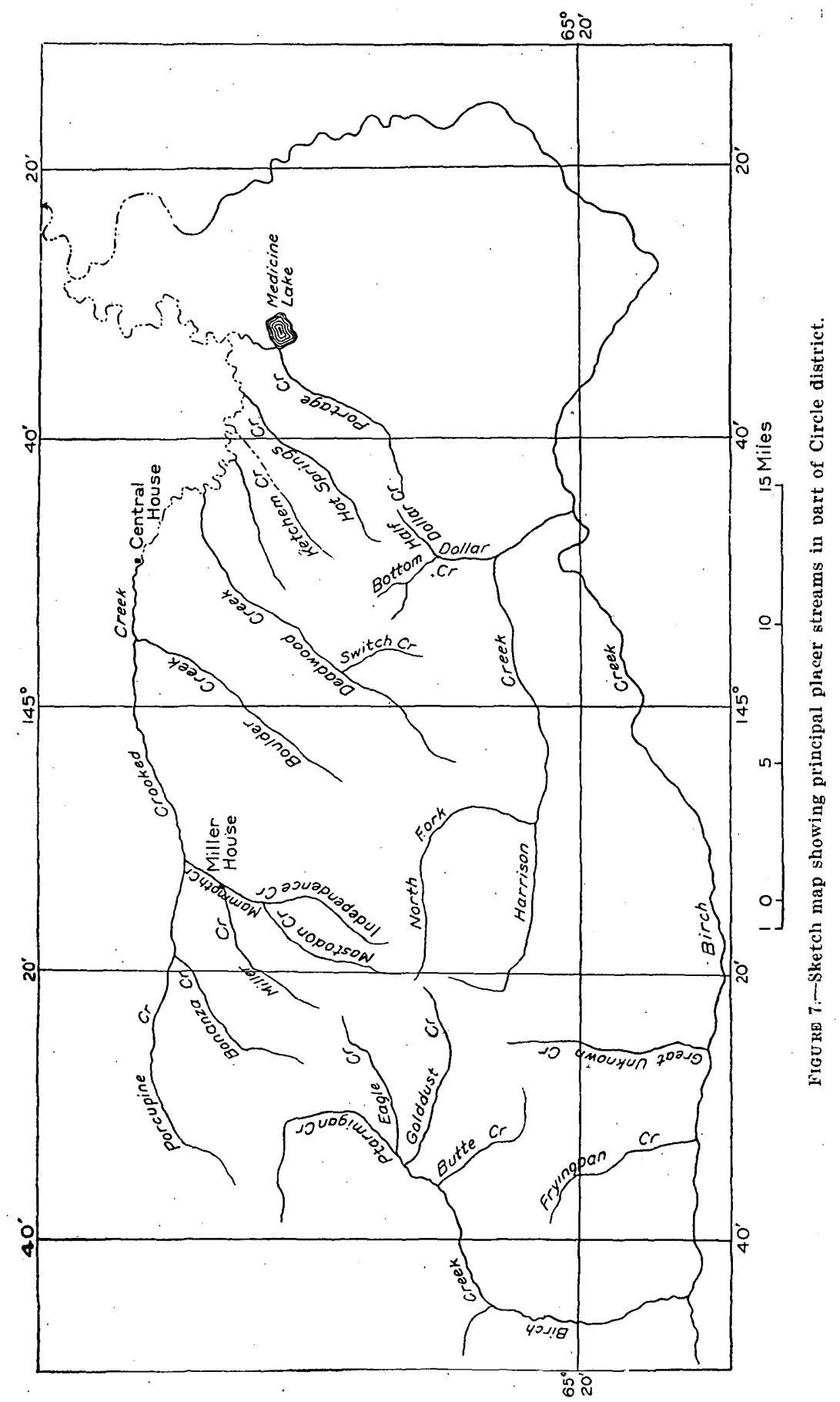


In the following table the various streams in the Crooked Creek area for which records of the fineness of their placer gold are available are listed in consecutive order from west to east.

Fineness of placer gold from Crooked Creek area, Oircle district, of Yukon region

\begin{tabular}{|c|c|c|c|}
\hline Creek & $\begin{array}{l}\text { Number } \\
\text { of records }\end{array}$ & $\begin{array}{l}\text { Range of } \\
\text { fineness }\end{array}$ & $\begin{array}{l}\text { Average } \\
\text { fineness }\end{array}$ \\
\hline 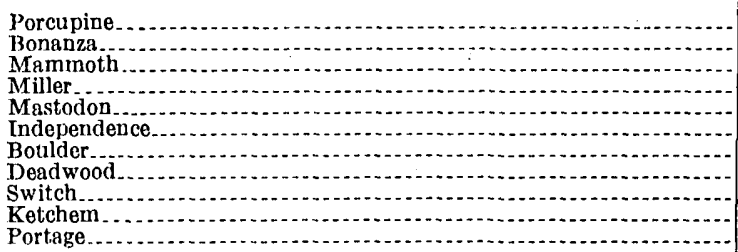 & $\begin{array}{r}3 \\
15 \\
1 \\
122 \\
218 \\
14 \\
2 \\
12 \\
10 \\
3 \\
2\end{array}$ & $\begin{array}{c}8181 / 2-834 \\
8111 / 2-869 \\
8281 / 4 \\
i 8041 / 4-862 \\
2718-8091 / 2 \\
7781 / 2-818 \\
911 \\
769-8173 / 4 \\
7501 / 4-7831 / 2 \\
783-784 \\
7511 / 2-789\end{array}$ & $\begin{array}{r}824 \\
850 \\
828 \\
1832 \\
2780 \\
795 \\
011 \\
793 \\
762 \\
784 \\
770\end{array}$ \\
\hline Totnl..... & 102 & & 808 \\
\hline
\end{tabular}

1 One record of 920 omitted.

2 One record of $8648 / 4$ and one of $8711 / 2$ omitted.

The records disclosed by the table do not fit at all satisfactorily any explanations that can now be advanced. The placers of the Boulder Creek Valley apparently afford gold of much higher fineness than those of any other stream in the area and seem to be out of line with all the records except one from a claim on Miller Creek that was omitted as being too discordant with all of the other records from that creek. The gold from the four westernmost streams in the area seems to have the next highest fineness, although there is no progressive increase or decrease in fineness in any direction. Thus, of the four western streams, Bonanza Creek seems to have gold of the highest fineness, followed in descending order by Miller, Porcupine, and Mammoth Creeks. East of these four creeks all the streams except Boulder Creek, already mentioned, seem to have gold that averages less than 800 fine, and there is the suggestion that on the whole the gold is progressively less fine toward the eastern part of the area. Possibly the trend is to be attributed to the fact that Deadwood, Switch, and Portage Creeks derive much of their placer material from the granites and contact zones that occur in the valleys of those streams. In the absence of more complete records, however, it is vain to attempt to carry such speculations far.

\section{BIRCH CREEK AREA ABOVE CROOKED CREEK}

As shown by the sketch map (fig. 7), Birch Creek above the mouth of Crooked Creek has a most circuitous course so that the tributaries at its extreme head rise on the southwestern slopes of Mastodon Dome, on whose northern slopes many of the tributaries of Crooked Creek have their origin. The bedrock throughout the area is essentially 
similar to that in the Crooked Creek area to the north; the intrusions of granitic igneous rocks are absent, however, except in the divide of the basin, where the granite abuts against the head of Portage Creek.

For convenience the fineness of gold from certain streams of this area for which records are available have been listed in the following table:

Fineness of placer gold from Birch Creek area above Croolced Creek, of Circle district, of Yukon region

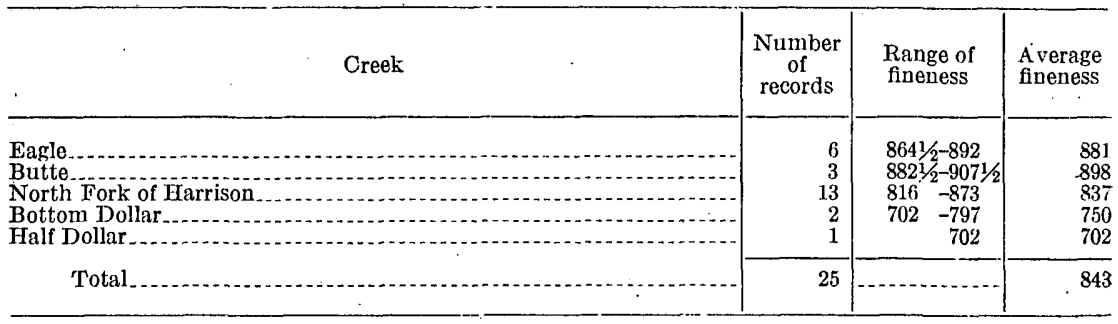

Comparison of this table with that given on page 187 brings out certain points of difference and similarity between the gold from the two areas. Although heading within a few miles of each other and apparently having much in common the headwater tributaries of Birch Creek-Eagle Creek and Butte Creek-have gold of much higher average fineness than that from the nearby tributaries of Crooked Creek, such as Miller or Mastodon Creeks. On the other hand, the fineness of gold on the North Fork of Harrison Creek does not differ markedly from that of Miller Creek on the north side of the divide, though it is much higher than that of the nearby Mastodon and Independence Creeks. Farther east in this southern area the fineness of gold from the placers on Bottom Dollar and Half Dollar Creeks bears some semblance to the gold from Switch and Portage Creeks to the north, though that from the more southern streams, according to the records, is of considerably lower grade. This comparison, however, is not to be given too much weight, because the number of records available is too small to give a thoroughly trustworthy basis for comparison.

\section{WOODCHOPPER-COAL CREEK AREA}

The Woodchopper-Coal Creek area differs markedly in its geologic features from either of the other areas in the Circle district that have been described. Although the headwaters of Woodchopper and Coal Creeks rise in a large intrusive granite area, as they flow northward they traverse successively rather narrow bands of Birch Creek schist, undifferentiated sedimentary rocks now considered as mainly Devonian, Tertiary sandstone, shale, and conglomerate, Carboniferous limestone and chert, Cretaceous sandstone, slate, and shale, and lastly, 
adjacent to the Yukon River throughout much of the area, they cut across ultrabasic and basic intrusive rocks of greenstone habit that are regarded as of Devonian age. In the main the valuable placer deposits in this area have been found in and downstream from those places where the Tertiary sediments form the bedrock. According to Mertie ${ }^{23}$ the accumulation of the gold in these placers has had a long and complex history. The gold is believed to have originated in quartz veins and stringers in the older rocks, from which it was weathered and later concentrated in the Tertiary sediments. These deposits in turn were subsequently weathered, and the gold they contained was concentrated by the later streams. The gold is reported to be bright and fairly coarse, which is rather unexpected in view of the diverse sorting and transportation it has undergone. Of the 15 records of fineness of gold from the area the range of fineness is between $8881 / 2$ and $9351 / 2$, and the average of all of these is about 905 .

\section{EAGLE DISTRICT}

The Eagle district embraces the country around Eagle that extends from the international boundary on the east for 40 miles or more to the west and includes the drainage basins of Seventymile River and Fourth of July Creek. To the south it is separated from the Fortymile district by a tract 20 to 30 miles wide in which no placer deposits of moment have been discovered. The placer mining in the Eagle district may be segregated into three more or less distinct areas here called the American Creek and vicinity, the Seventymile, and the Fourth of July Creek areas. On the whole there is a fair degree of uniformity in the fineness of gold from these different areas, but in order that such differences as have been observed may be pointed out, each area will be discussed briefly in the following pages.

\section{AMERICAN CREEK AND VICINITY}

The highlands, in which rise many of the streams adjacent, to Eagle, have for their bedrock undifferentiated sedimentary rocks that are of Devonian or older age. Near the Yukon these are succeeded by a broad belt of Tertiary rocks, which are interrupted here and there, as in the hills below Eagle, by islandlike areas of Carboniferous and other Paleozoic rocks. Presumably most if not all of the gold in the placers of this area was originally derived from the veins that were formed in the Paleozoic rocks through the processes attendant on the intrusions of the large bodies of igneous rocks that now form extensive outcrops in Glacier Mountains and other nearby tracts. Subsequently,

\footnotetext{
\$ Mertie, J. B., Jr., Geology of the Eagle-Circle district, Alaska : U. S. Geol. Survey Bull. 816, pp. 165-168, 1930; Gold placers of the Fortymile, Eatgle, and Circle districts, Alaska : U. S. Geol. Survey Bull. 897-C, pp. 251-257, 1938.
} 
much of the detritus worn from these rocks was redeposited to form the Tertiary rocks that have already been referred to. These rocks in turn have been subjected to renewed erosion and reconcentration of the valuable heavy minerals they contained. Many of the placers of American Creek and vicinity, therefore, have passed through a long and intricate series of events, but some of the placers evidently are of later formation and have undergone less repeated concentration. Some hint of this condition is afforded by the variation in the fineness of the gold that is recovered from the placers in the several valleys. Thus five records that are available show the gold of this area to range in fineness from 8581/2 to 902 , with an average of 881 . One record from Boundary Creek, whose valley has been cut entirely within the area occupied by undifferentiated metamorphic schists, shows a fineness of $8493 / 4$.

\section{SEVENTYMILE AREA}

The eastern and northern parts of the valley of Seventymile River lie almost entirely within the area occupied by the Tertiary sedimentary rocks, though the higher land to the south, in which its southern tributaries rise has diverse kinds of rocks, including the old preCambrian schists, metamorphic undifferentiated Paleozoic or older rocks, and large and small outcrops of intrusive igneous rocks of granitic character. The belts of older rocks trend across the general course of Seventymile River so that west of a point near Barney Creek they form the dominant bedrock both to the north and to the south of the river and thus take the place of the Tertiary rocks that crop out farther east. There is a marked difference in the fineness of the gold from those creeks in the eastern part of the area whose valleys have been cut into the 'Tertiary bedrock. For instance, 23 determinations of the fineness of gold from Fox and Crooked Creeks, which join Seventymile River from the north, show an average fineness of 904 and a range from 8811/4 to 9121/2. Barney Creek, still farther upstream and lying mainly near the margin of the Tertiary area, has gold with a fineness of 875 , according to the one record at present available to the Geological Survey. On the other hand, the record of the gold from the placers on Nugget and Alder Creeks, which are in the schist area, show that the average of the 10 observations available is 842 and that the extremes are 836 and $8503 / 4$. Some departure from the foregoing generalization is afforded by four records from Broken Neck Creek. 'This stream lies dominantly within the area occupied by Tertiary rocks, but the average fineness of its gold is more characteristic of that from the schist areas. The average fineness shown by the records from Broken Neck Creek is 830 , with extremes of $8251 / 2$ and 834 . 
Although in the northern or downstream portion of the Fourth of July Creek Valley the bedrock is composed of Carboniferous limestone and other Paleozoic rocks the southern part of the valley, in which most of the placers are located, is carved almost exclusively in member's of the 'Tertiary sequence. As might be expected, the character of the gold from these placers resembles in fineness the gold from the Tertiary areas on Seventymile River and in the Woodchopper-Coal Creek area of the Circle district. The 23 records of gold from the placers of Fourth of July Creek show an average fineness of 892 and range from $8483 / 4$ to $9161 / 4$. According to Mertie ${ }^{24}$ there is little question that the placer gold was derived from veins in the older rocks from which it was released by weathering and subsequently transported and built as an integral part of the Tertiary conglomerate and sandstones. Later weathering and erosion of the Tertiary rocks released the gold contained in them, and thus a second concentration was effected, this time by the post-Tertiary streams and attendant processes.

\section{FAIRBANKS DISTRICT}

The greatest production of placer gold from any of the Alaska districts has been that from the Fairbanks district. According to the records of the Geological Survey, the total production of placer gold from this district from 1903, when mining began, through 1936, has been more than $\$ 104,000,000$. An earlier study of the fineness of gold in this district was published ${ }^{25}$ in 1913 , based on some 167 records that were then available. "The results of that study have been freely consulted in the preparation of the present report, but the records that have been used in this later report are from entirely different sources and probably do not duplicate any of those used in the earlier report. Evidence in support of this conclusion is afforded by the fact that of the 155 determinations used in the present study only 12 relate to gold produced before 1913, whereas obviously all the determinations for the 167 records used in the earlier report were made before that year. Although there are some discrepancies between the two sets of records there is surprisingly close general agreement.

The principal producing placer areas in the Fairbanks district are more or less closely restricted to two areas northeast of Fairbanks and one area west of the town, but there are four more distant tracts in. which placer gold has been mined and which will be discussed in the

\footnotetext{
\& Mertie, J. B., Jr.. Gold placers of the Fortymile, Eagle, and Circle districts, Alaska: U. S. Geol. Survey Bull. 897-C, pp. 201-204, 1938.

"Smith, P. S., The fineness of gold in the Fairbanks district, Alaska: Econ. Geology, vol. 8 , pp. $449-454,1913$.
} 
following pages. The two areas northeast of Fairbanks-the Goldstream area and the Chatanika area-have been named from the principal streams flowing through them, but it should be understood that these names are mere catch-titles, and the areas discussed include not only the valleys of the main streams but also those of their tributaries. The area west of Fairbanks-the Ester area-has the name of a former settlement there as well as that of one of the principal streams. East of the head of the Goldstream Valley and south of Chatanika River is Fish Creek, with its numerous tributaries, including Fairbanks Creek. This area has been designated the Fish Creek area. Some distance east of Fairbanks the few small scattered placers that have been mined in the valleys of Chena and Salcha Rivers have been grouped together under the name of Chena-Salcha area. Some 50 miles northeast of Fairbanks and forming a more or less isolated tract are placers on some of the small headwater creeks of Chatanika River, which rise in the highlands between that stream and the tributaries of Birch Creek in the Circle district. The seventh and last area that has been distinguished in the Fairbanks district is some 40 miles or more north and slightly east of Fairbanks and about the same distance east of Livengood, in the Tolovana district. The principal stream draining this area is Nome Creek, and that name has been used to designate this area. It should be remembered, however, that the Nome Creek area is not to be confused with the much better known settlement of Nome and Nome River, in Seward Peninsula, more than 500 miles west of Fairbanks.

\section{GOIDSTREAM AREA}

The Goldstream area lies north of Fairbanks and has for the bedrock throughout the larger part of its valley a variety of highly metamorphic schists of pre-Cambrian age that are grouped together under the name Birch Creek schist. In the highlands bounding the Goldstream Valley both to the north and to the south are small areas of granitic igneous intrusives that cut the schists and are regarded as not older than late Mesozoic. Apparently some of the activities accompanying these intrusions were instrumental in causing mineralization which has been the source of the gold found in the placers of the nearby streams and in the lodes that have been successfully opened up. This: condition is especially evident in the vicinity of Pedro Dome, which forms part of the divide between the basins of Goldstream on the south and Chatanika River on the north. This relation has been discussed in some detail in the publication by Smith, ${ }^{26}$ already referred to. In the table on page 157, the 65 available records from the entire Goldstream area have been tabulated together with the results set down.

s Smith, P. S., op. cit. 
This consolidation, however, obscures certain relations of the distribution of fineness. In the following table that record is broken down further to show the records from the individual valleys.

Fineness of placer gold from Goldstream area, Fuirbanks district of Yukon region

\begin{tabular}{|c|c|c|c|}
\hline Creek & $\begin{array}{l}\text { Number } \\
\text { of records }\end{array}$ & $\begin{array}{l}\text { Range of } \\
\text { fineness }\end{array}$ & $\begin{array}{l}\text { Average } \\
\text { flneness }\end{array}$ \\
\hline $\begin{array}{l}\text { Main Goldstream } \\
\text { Gilnore. } \\
\text { Engineer-_. } \\
\text { Fox } \\
\text { Pedro... }\end{array}$ & $\begin{array}{r}126 \\
5 \\
6 \\
5 \\
219 \\
4\end{array}$ & 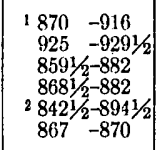 & $\begin{array}{r}1908 \\
928 \\
874 \\
875 \\
2874 \\
868\end{array}$ \\
\hline Total & 65 & -...... & 891 \\
\hline
\end{tabular}

1 Only two records below 900 .

2 Only one record below 856 .

From the foregoing table it will be seen that practically all of the gold from the main Goldstream Valley and its direct continuation Gilmore Creek is of high purity, averaging well over 900 fine. The gold from what may be considered the side streams, including Pedro Creek, is all much lower, averaging from 868 to 875 . For these streams the table shows no record of gold higher than $8941 / 2$ and only one record below 856. The foregoing statement regarding the gold from Engineer Creek is at variance with the records shown in the earlier tabulation by Smith, referred to. In that statement several observations were recorded, all of which showed that the gold from Engineer Creek hat a fineness of 913 or higher. No explanation of the reason for the discrepancy between the two records can be offered at this time. Determination as to which is correct is of considerable importance because the high fineness suggests that the gold had probably been transported a considerable distance, whereas the low fineness suggests a more local source.

\section{CHATANIKA AREA}

The principal productive part of the Chatanika Valley lies immediately north of the productive part of the Goldstream Valley. The northward-flowing tributaries of the Chatanika Valley rise in the same highland as the southward-flowing tributaries to Goldstream. Many of the general geologic features of the valley of Chatanika River have much in common with those of the Goldstream Valley, which have been described. The Chatanika Valley, however, because of its much greater length, has also many features not shared by its smaller neighbor to the south. From the table on page 157 it will be seen that on the whole the gold from the placers in the valley of Chatanika River is of lower fineness than that from Goldstream and its tribu- 
taries. In order that a somewhat more detailed analysis may be made of the distribution of the fineness of placer gold in this area the records have been broken down to show the individual stream valleys from which the gold was recovered. Those results are set forth in the following table.

Fineness of placer gold from Chatavika area, Fairbanks alistrict, of Yukon region

\begin{tabular}{|c|c|c|c|}
\hline Creeks & $\begin{array}{l}\text { Number } \\
\text { of records }\end{array}$ & $\begin{array}{l}\text { Range of } \\
\text { fineness }\end{array}$ & $\begin{array}{l}\text { Average } \\
\text { fineness }\end{array}$ \\
\hline $\begin{array}{l}\text { Main Chatanika } \\
\text { Vault } \\
\text { Treasure } \\
\text { Dome } \\
\text { Little Eldorado } \\
\text { Cleary } \\
\text { Wolf } \\
\text { Chatham } \\
\text { Kokomo }\end{array}$ & $\begin{array}{r}3 \\
1 \\
2 \\
5 \\
10 \\
12 \\
14 \\
3 \\
1\end{array}$ & \begin{tabular}{ll|}
863 & -878 \\
& 870 \\
866 & -910 \\
877 & -893 \\
860 & $-8783 / 4$ \\
$8361 / 2-8791 / 2$ \\
823 & -834 \\
$8211 / 2-8311 / 2$ \\
900
\end{tabular} & $\begin{array}{l}871 \\
870 \\
888 \\
887 \\
867 \\
856 \\
828 \\
824 \\
900\end{array}$ \\
\hline Total & 51 & & 857 \\
\hline
\end{tabular}

As will be readily apparent, there are few records of gold from the main valley of Chatanika River itself, and this correctly portrays the fact that in general there has been little or no mining in that part of the area. Such mining as has been done there has been principally along the old buried courses of the side streams, which, in places, extended out across the now broad lowland of the main river. Thus, practically all the records concern gold from the side streams, and many of them are from placers near the heads of valleys. The low fineness shown by the records from Wolf and Chatham Creeks, which are tributaries of Cleary Creek and are in tracts "whose bedrock is known to be highly mineralized in places, is probably due to the nearness of the placers to their original source.

\section{UPPER CHATANIKA AREA}

The extremely high fineness of gold from the deposits near the head of Chatanika River, which has here been designated the Upper Chatanika area, presents a condition for which at present there is no satisfactory explanation. The localization of the deposits there seems to indicate that the material has been derived from a nearby source and theoretically the gold contained in the deposits should be of moderate to low fineness. The bedrock geology in the vicinity of the deposits does not differ materially from that in the Goldstream or Chatanika areas in that the general country rock is Birch Creek schist, which in places, especially as in the highlands north of Chatanika River in the divides adjacent to Faith, Hope, and Sourdough Creeks, has been intruded by masses of granitic igneous rocks. Nine records of gold from Sourdough Creek show finenesses that range from $9221 / 2$ to 925 , 
and one record each from Faith Creek and its tributary, Homestake Creek, show identical records of fineness of $8961 / 2$. It is evident therefore that the quality of gold from these deposits differs in a marked degree from gold in other areas that has been derived from nearby sources. This may mean that instead of being derived from nearby rocks mineralized by the igneous intrusions the gold has really come from a more remote source. Speculation on this subject in the absence of more definite records is inconclusive.

\section{ESTER AREA}

The known placer deposits in the Ester area are more or less closely restricted to places along the southern and southeastern flanks of Ester Dome. Ester Dome itself is the site of considerable lode deposits, some of which have been large enough and rich enough to permit profitable lode mining. The bedrock throughout the area consists of members of the Birch Creek schist and a few small granitic intrusions. The Tertiary and quaternary history of the processes that have affected this area and the deposits that have been formed in it is extremely complex. Deeply buried old stream channels 100 feet or: more deep, lying athwart some of the existing stream courses have been discovered, though the full extensions of some of the old courses have not even yet been satisfactorily determined. There can be little doubt, however, that the greater part of the gold is distinctly of local origin, having come from the numerous veins and stringers abounding in the Birch Creek schist of the area. Unfortunately the number of records available from the source used in the present study is too small to permit adequate determination of the real distribution of fineness in the Ester area. A more adequate representation is afforded by the earlier article by Smith, ${ }^{27}$ which showed that at the head of Ester Creek the fineness averaged about 800 ; that farther downstream it increased irregularly, until at the junction of Cripple and Ester Creeks it was somewhat more than 860 . In the records from which the statements in the table on page 157 were prepared, only three assays of gold from Ester Creek proper were available. These showed fineness ranging from 807 to 830. One record of a bench deposit on Eva Creek, a tributary of Ester Creek, showed gold with a fineness of 842 . A record from Cripple Creek showed 869 fine gold, one from Gold Hill showed 859, and four records from St. Patrick Creek and its tributary, Shamrock Creek, ranged from 835 to 855 fine and averaged 843 . The extensive mining operations in progress in this area should afford a wealth of information as to the fineness of gold in the different tracts and in the deposits of different types that should be invaluable in

$\approx$ Smith, P. S., op. cit. (Econ. Geology, vol. 8), pp. 449-450. 
determining some of the facts responsible for the variations that are known to occur there. Correct interpretation of these factors might go far in enabling the geologist to aid in the search for extensions of the known deposits or of intelligently extending prospecting to areas that appear significant.

\section{FISH CREEK AREA}

Fish Creek is a stream whose headwaters and tributaries from the west rise in the highlands adjacent to the head of Goldstream and some of the southern tributaries to Chatanika River. It has an extremely circuitous course, finally flowing into Little Chena River some 25 to 30 miles northeast of the town of Fairbanks. The bedrock throughout the greater part of its valley is dominantly the varied metamorphic rocks of the Birch Creek schist. Up to the present time there have been two principal sites of placer mining in this valley-one in the headwater portion of Fish Creek and the other on Fairbanks Creek, which is a tributary from the west that enters the main stream some 10 to 12 miles due east of Pedro Dome. The gold from these two tracts within the Fish Creek area differs greatly. The seven records from the deposits on Fairbanks Creek show a range in fineness of 835 to $8751 / 4$ and an average of 864. On the other hand, the five records from the deposits near the head of Fish Creek show a range in fineness of 892 to 924 and an average of 913 . In seeking to explain the wide difference in the fineness of the gold from the two localities, one faces the fact that there is no obviously apparent difference in the geology of the two tracts. It is true that the known mineralization in the vicinity of Fairbanks Creek is more intense than in the headwaters of Fish Creek. For example, a number of lode deposits that have been mined intermittently in the past are known at several places on the divide at the head of Fairbanks Creek, and one of the largest operating lode mines in the entire Fairbanks district has been active for many years on one of the short tributaries of Fairbanks Creek that enters from the north about midway in the valley of the main stream. No such lode deposits are known in the immediate vicinity of the head of Fish Creek, but in that locality the relation of schist and intrusive rocks seems similar to those that have produced mineralization elsewhere. The fineness of the gold from the head of Fish Creek is not dissimilar to that of the gold to the west on Gilmore Creek where high-grade gold also occurs.

\section{GHENA-SALCHA AREA}

Little placer mining has ever been in progress in the area east of Fairbanks that embraces the great drainage basins of Chena and Salcha Rivers. A few records of the fineness of gold from some of 
the small camps, however, have become available in the series of records and are of particular interest because of their rarity. Two of the records are from Palmer Creek, a small tributary of Chena River from the south that joins that stream about 50 miles in an air line slightly north of due east of the town of Fairbanks. The bedrock in the valley of this stream is composed of metamorphic rocks that are regarded as probably younger than the Birch Creek schist though they are not assigned to a more specific age than to the pre-Middle Ordovician. The range of fineness of the gold from the Palmer Creek deposits is 831 to $8381 / 2$, with a mean of about $8341 / 2$.

One of the available records from the Chena-Salcha area is of gold from Steele Creek, which is a tributary of Chena River from the North. It rises in the highland that forms the divide of Goldstream and its tributaries Engineer and Gilmore Creeks and joins Chena River, some 8 miles east of the town of Fairbanks. The single record of fineness available from this valley shows that the gold is $8961 / 2$ fine.

One record is also available as to the fineness of the gold from Caribou Creek, a tributary of Salcha River from the north that enters that stream about 60 miles a little south of due east of Fairbanks. The extreme northern or headward part of the valley of this stream has for its bedrock members of the undifferentiated pre-Middle Ordovician sequence. These rocks are cut by several small granitic intrusives. The southern part of the valley of Caribou Creek is cut predominantly into members of the old Birch Creek schist, greenstones, and other basic intrusive rocks that form extensive tracts in the neighborhood of the valley of Caribou Creek though they do not form noteworthy features in the valley itself. The one available determination of the quality of gold from this valley shows a fineness of 906 . From all the other known facts it would have been supposed that the gold in these deposits was of extremely local origin and would have a relatively low fineness. The reason for its high fineness, therefore, presents a problem for which no satisfactory explanation can be given at this time.

\section{NOME CREEK AREA}

Only one record of the fineness of gold in the Nome Creek area is at present available to the Geological Survey so that until many more can be studied any statement of the quality of gold occurring there must be regarded as merely tentative, even though that record is based on a shipment of several thousand ounces of gold dust. This determination showed that the gold was 918 fine. The general bedrock in the vicinity of Nome Creek is Birch Creek schist, but at the head of the creek is a considerable area occupied by intrusive igneous rocks of 
granitic type. In fact, this is part of the same general area of granite that occurs in the valleys of Hope and Sourdough Creeks of the Upper Chatanika area. The high fineness of the gold on Nome Creek may be attributable to the same causes as those that were responsible for the high fineness of the gold in the nearby area, though those causes have not yet been determined. It would appear that the gold found on Nome Creek was of fairly local origin, but that it has undergone considerable transportation is indicated by the small size of the individual particles. The mined ground was rather shallow, and very little of it was permanently frozen. These conditions may partly explain the especially high fineness of the gold.

\section{FORTYMILE DISTRICT}

The Fortymile district, as the term is used in this report, embraces all the country drained by Fortymile River and its tributaries adjacent to the international boundary and lying south of the Eagle district. For a general description of the geology of the district the most recent and most comprehensive report is that by Mertie. ${ }^{28}$ The placer deposits in this large tract are widely distributed but may be grouped into four more or less distinct areas that have been designated here by the name of the principal stream in whose valley the deposits occur. These are the Fortymile River, South Fork, Mosquito Fork, and Walker Fork areas. As will be seen from the table on page 158, the greater number of records from this district show finenesses of 800 to 849 , with only about a third falling in the range of 850 to 899 , only two records showing fineness lower than 800 , and one showing fineness higher than 900 . Throughout the entire district the oldest rocks are members of the Birch Creek schist, into which have been intruded in the late Mesozoic or later time various granitic rocks of deep-seated origin. In the vicinity of the settlement of Chicken, a part of the bedrock is effusive igneous rock of acidic composition. East of Chicken a considerable tract is occupied by undifferentiated rocks of middle Paleozoic age that were probably deposited in the main during the Devonian. A few small tracts of widely scattered Tertiary sandstones and conglomerates have been recognized through the district, and some high, level terraces that may also have been carved during the late Tertiary form conspicuous features of the landscape, especially in the eastern part of the valley of the main Fortymile River.

\section{FORTYMILE RIVER AREA}

Most of the mining along the main course of Fortymile River has. been small-scale hand work confined largely to the river bars and

\footnotetext{
${ }^{28}$ Mertie, J. B., Jr., Gold placers of the Fortymile, Eagle, and Circle districts, Alaska: U. S. Geol. Survey Bull. 897-C, pp. 133-261, 1938.
} 
places that could be worked during low stages of the river. Seven reterminations of the gold recovered from this part of the area show a range of $7951 / 4$ to 841 ; the average of all these observations is 809 . The gold from the side streams to Fortymile River in this part of the valley is of much higher fineness. Two determinations of the gold from Smith Creek show an average fineness of 831; two from Squaw rreek, $8431 / 2$; and two from Dome Creek, 8841/2. Owing to the small number of records available for consideration, there is little justification in attempting to explain the reason for the difference between the fineness of the gold from the main stream and that from the tributary streams. It seems possible, however, that the gold in the tributary valleys may have undergone longer and more intense weathering and sorting than the gold in the valley of the main stream, which may have been derived more immediately from local sources fnd so had been subjected to fewer cycles of handling by the natural processes. Such an explanation, however, does not fit well with the known facts that much of the gold from the river bars is in small flakes that appear more worn than the heavier pieces that are more characteristic of the placers on the tributary streams.

\section{SOUTH FORK AREA}

In the valley of South Fork of Fortymile River the principal placer mining camps have been in the valleys of Butte, Buckskin, and Franklin Creeks, which join the main stream from the west, and on Napoleon Creek, which joins it from the east. Only one record of the fineness of gold from the valley of Buckskin Creek is available, and that is from a tributary from the north known as Forty-five Gulch. This side stream heads in a large granite mass that forms the divide between streams flowing northward into tributaries of the North Fork and those flowing southwestward into tributaries of the Mosquito Fork: The gold from Forty-five Gulch is apparently exceedingly impure, the single record available showing a fineness of 620 . This record thus indicates the lowest fineness of the entire Yukon region, with the exception of a single area in the Kantishna district. Franklin Creek, which enters the South Fork a few miles upstream from Buckskin Creek, has a course nearly parallel to and only slightly removed from the contact between the area of Birch Creek schist and the great granite area to the south that forms Mount Taylor and the highlands between Dennison and Mosquito Forks. The gold from Franklin Creek is of rather low fineness, judging from the single available record from placers in its valley. This record shows a fineness of 817 .

The bedrock geology of the Napoleon Creek Valley is rather complex, as a number of formations of different ages have been recognized within its confines. On the whole, however, the greater part of the 
valley has been carved on metamorphic rocks of the Birch Creek schist that have been cut by later granite intrusives that now crop out in several small areas, most of which are in the divides that circle the northern part of the valley. 'Ten records of the fineness of gold from Napoleon Creek show a range of 851 to 869 , and the average of all these observations is 862 .

\section{MOSQUITO FORK AREA}

Placer mining in the Mosquito Fork area of the Fortymile district has centered rather closely around the settlement of Chicken, which is not far from the contacts of the great granite massif to the south that forms much of Mount Taylor and vicinity, the undifferentiated Paleozoic rocks that are presumably Devonian, and the rhyolitic and dacitic effusive rocks of early Tertiary age. In addition to these rocks that form extensive tracts in the area, there are some small areas occupied by Tertiary sandstones and conglomerates that in places are coal bearing. As will be seen from the general table on page 158 , all the records of the fineness of gold in the Mosquito Fork area show gold ranging from $8023 / 4$ to $8751 / 2$. Of the 41 records from this area 33 are between $8023 / 4$ and $8491 / 2$. Analyzing all the available records on the basis of the individual stream valleys to which they apply gives the results set forth in the following table. The moderately high fineness of the gold from Lost Chicken Creek appears to be due in part at least to the fact that much of the valley of this stream has been cut in terrace deposits. These deposits were formerly much more extensive but are now present. only in the ridge between Chicken and Lost Chicken Creeks. This gold therefore probably underwent at least one period of concentration prior to the time it was subjected to the recent handling by the present stream. The two extremes of fineness recorded from other streams are $8023 / 4$ for the gold from Stonehouse Creek and the average of 851 for that from Ingle Creek. It would seem entirely reasonable to explain the low fineness of the gold from Stonehouse Creek as due to the fact that that stream is a very small headwater gulch heading up into the mass of igneous rocks. Such an explanation, however, appears to run counter to the fact that no gold of such fineness is recovered from Myers Fork, although that valley also bears similar relations to the granites. The foregoing explanation seems even more untenable when it is realized that the whole valley of Ingle Creek lies entirely within the limits of this same granite mass and yet its gold has a higher average fineness than that from any of the other valleys in the area except that of Lost Chicken Creek. Possibly the explanation of the higher fineness of the Ingle Creek gold lies in its derivation through reconcentration from older bench deposits, perhaps like those near Lost Chicken Creek. 
Fineness of placer gold from Mosquito Forli area, Fortymile district of Yukon region

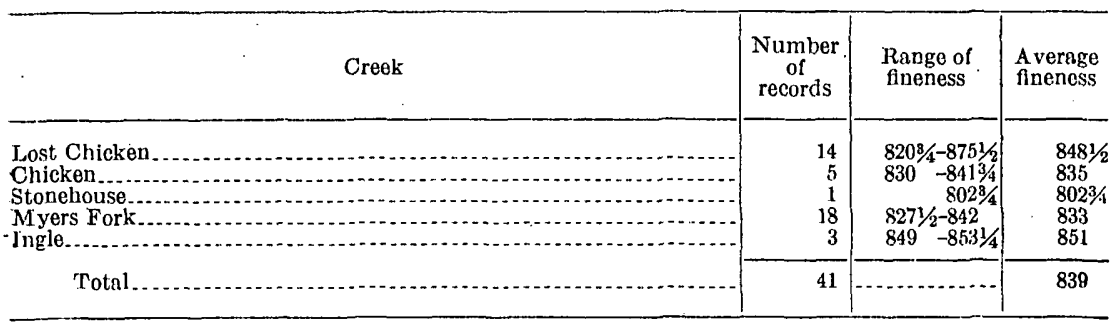

Walker Fork is the large tributary that joins the South Fork from the east a short distance south or upstream from Napoleon Creek. Its principal tributary is Wade Creek, which joins it some 5 miles in an air line east of its junction with the South Fork. The bedrock throughout the entire drainage basin of Walker Fork is Birch Creek schist in which are a number of small intrusive masses of deepseated igneous rocks of the granitic type. Only three determinations of the fineness of gold from the main valley of the Walker Fork are available, and they vary so widely that some doubt is felt as to their reliability. These records have a range of 830 to 904 , with a mean of 875 . For Wade Creek, however, 23 records are available, the range of which is $8071 / 2$ to 865 , and the average 834 . 'There seems to be no systematic order shown by the records as to the increase or decrease of fineness from the head to the mouth of the valley. In fact there is a rather striking uniformity in the records, for only three are above $8501 / 2$ and only three are below 823 . Poker Creek, a small stream that is tributary to Walker Fork near its extreme head just west of the international boundary, has afforded three records of the fineness of gold found in its valley. These records show that the gold ranges in fineness from $8711 / 2$ to $874.1 / 2$ and has an average of 873 . This surprisingly high fineness of the gold from a tract where it would seem that the material must have been derived from a distinctly local source without having undergone much transportation presents a problem for which there seems yet to be no adequate explanation.

\section{GOLD HILL: DISTRICT}

Lying some 30 miles west of the settlement of Tanana, at the junction of the Yukon and Tanama Rivers, and embracing a rather inrlefinite tract of country north of the Yukon, is a placer area that in the past has been the scene of small mining developments. This is here referred to as the Gold Hill district. The principal valleys where mining has been done are Grant, Illinois, and Mason Creeks, 
direct tributaries of the Yukon, and Moran Creek, a tributary of Little Melozitna River, which in turn flows into the Melozitna River, which joins the Yukon nearly north of Ruby.

The geology of this district has been described briefly by Maddren and Eakin, ${ }^{29}$ and the general features are represented on the map that accompanies Mr. Eakin's report. The oldest members of the bedrock are highly metamorphic schists, limestones, and quartzites that are not younger than early Paleozoic age and may even be prePaleozoic. These rocks have been intruded by granitic rocks so altered and so metamorphosed that they now have distinctly gneissic structure. These gneissic granitic rocks are entirely distinct and are much older than other granitic rocks that form much of the divide at the head of Moran and Illinois Creeks and that probably are not older than late Mesozoic. Gold-bearing quartz veins have been found in the hills near the placer camps. The mineralization of these veins, which were doubtless the source of the placer gold, seems to have been associated with the intrusion of the younger rather than the older granitic rocks. The placer gold is described by Maddren as occurring in small chunks, some of which, as for instance those found near the head of Moran Creek, are rounded pellets about the size of bird shot.

Only one record of the fineness of the gold from this district is now available to the Geological Survey. It indicates that the gold has a fineness of approximately 895. A single record is insufficient to serve as more than a suggestion of the true fineness of the gold that the area holds, but in the absence of more complete information it is highly significant.

\section{HOT SPRINGS DISTRICT}

In the southwestern part of the triangle between the Yukon and Tanana Rivers are several placer mines that are scattered within a radius of 25 miles or so of the small settlement of Hot Springs, near the Tanana River. These mines may be further segregated into those to the northeast of Hot Springs and those to the west of that town. The camps in the northeastern part will be referred to as in the Eureka area; those to the west will be referred to as in the Tofty area. The sedimentary bedrock in the Hot Springs district belongs to a number of different formations, ranging from pre-Ordovician schists and related rocks through Silurian, Devonian, to and includ-

\footnotetext{
${ }^{20}$ Maddren, A. G., The Innoko gold-placer district, Alaska, with accounts of the central Kuskokwim Valley and the Ruby Creek and Gold Hill placers: U. S. Geol. Survey Bull. 410. pp. 80-83, 1910. Eakin, H. M., The Yukon-Koyukuk region, Alaska : U. S. Geol. Survey Bull. 631, p. 35 and pl. 2, 1916.
} 
ing Carboniferous, followed much later by Cretaceous sandstones and shales. In the area where the placer deposits have been mined, the bedrock is almost exclusively the Cretaceous sediments according to Mertie, ${ }^{30}$ except where these rocks have been intruded by granitic igneous rocks, as Hot Springs and Eureka Domes, Roughtop, Elephant, and Wolverine Mountains, and at a fei less conspicuous points.

As will be seen from the table (p. 158), the greater number of the available records of fineness of gold from the Hot Springs district show only moderate to low fineness, nearly 50 percent being below 800 and 85 percent being below 850 . It will also be evident that the gold of low fineness comes mainly from the Eureka area, as over 80 percent of the records of that area show fineness below 800, whereas more than 88 percent of the records from the Tofty area shown fineness above. that figure.

\section{EUREKA AREA}

Most of the creeks in the Eureka area on which placers have been found head in the highlands that form the watershed separating them from the northward-flowing streams of the Rampart district. In this highland several small bodies of intrusive igneous rock have cut through the Cretaceous sandstone and shale that form most of the bedrock of the area. In general, according to Mertie, mineralization in the Eureka area seems to have resulted in the formation of numerous quartz veins that are more or less restricted to a southwestwardtrending. zone of shearing. This gold that was originally carried in some of these veins was released through processes of weathering and erosion and subsequently concentrated to form the placers that have been mined. According to Mertie, this concentration has been effected without much transportation, so that the original source, the goldbearing veins, is believed to have been not far from the site of the present placers. This conclusion seems to fit well with the fact that the placer gold from this area is of especially low fineness.

As has been stated, more than 80 percent of the available records of the fineness of the placer gold from the Eureka area show less than 800 parts of gold in the bullion. In order that a somewhat more detailed analysis of the 28 records from this area may be available, the following table has been prepared to show some of the pertinent facts regarding the gold from the various individual creeks.

${ }^{\text {so }}$ Mertie, J. B., Jr., Mineral deposits of the Rampart and Hot Springs districts, Alaska : U. S. Geol. Survey Bull. 844-C, pp. 163-226, 1934. 


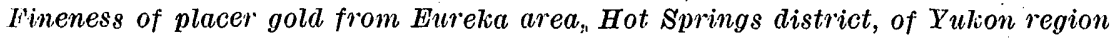

\begin{tabular}{|c|c|c|c|}
\hline Creek & $\begin{array}{l}\text { Number } \\
\text { of records }\end{array}$ & $\begin{array}{l}\text { Range of } \\
\text { fineness }\end{array}$ & $\begin{array}{l}\text { Average } \\
\text { fineness }\end{array}$ \\
\hline $\begin{array}{l}\text { Eureka } \\
\text { Rhode Island } \\
\text { Gold Run } \\
\text { Glen Gulch } \\
\text { Pioneer } \\
\text { McCaskey Bar } \\
\text { Omega } \\
\text { Chicago Creek }\end{array}$ & \begin{tabular}{r|r}
19 \\
1 \\
1 \\
27 \\
4 \\
1 \\
4 \\
1
\end{tabular} & $\begin{array}{rr}774 & -8361 / 4 \\
7801 / 2 \\
774 \\
7371 / 2-797 \\
773 & -7821 / 2 \\
784 & -786 \frac{1}{2} \\
784 & 7878 \\
& 7\end{array}$ & $\begin{array}{r}1799 \\
780 \\
774 \\
2785 \\
779 \\
803 \\
785 \\
788\end{array}$ \\
\hline Total & 28 & 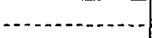 & 784 \\
\hline
\end{tabular}

1 Two records only above 803.

i One record only below 773 .

As is evident from this table, the gold from the placers on these various streams is remarkably uniform, for if we except 2 records that appear inordinately high and 1 that appears to be inordinately low, all the other 25 range between 773 and 8023/4. Much of the gold from Eureka Creek is described by Mertie as bright and chunky, and goodsized nuggets to some of which quartz still clings are not uncommon. The gold from Pioneer Creek is described by Mertie as well-worn and light-colored; that from Rhode Island Creek is light-colored, shotty, and somewhat worn, though the original crystalline outline is recognizable on some of the pieces; nuggets worth at the old price of gold as much as $\$ 38$ and $\$ 48$ have been found on Omega and Chicago Creeks, respectively. The gravel in most of the placers is rather angular, as though it had not been carried far from its point of origin.

\section{TOFTY AREA}

Although, as already noted, the general bedrock in the Tofty area appears to be essentially identical with that of the Eureka Creek area, the fineness of its gold is apparently considerably higher than that of the Eureka area. The fact that the Tofty area seems to have been subjected to deeper erosion may possibly account for part of that difference, but other causes not yet determined doubtless also had a share in producing this result. In the following table the order in which the creeks have been arranged has been from east to west. This, on the whole, has resulted in placing first the streams heading in or near: the vicinity of the granitic intrusive that forms the higher part of Roughtop Mountain. In other words, the placers on Cache, Dry, and Sullivan Creeks are rather close to the igneous mass, whereas Woodchopper and American are successively farther away from this body. Possibly this condition is reflected in the difference in fineness of the gold from the three first-named creeks, which ranges on the average from 781 to 818 , as contrasted with that from the three last named, which ranges on the average from 841 to 852 . There are, however, many other differences between the physical conditions prevailing in 
these two tracts, because, while most of the mining in the vicinity of American Creek is on shallow ground, most of the placer mining in the valley of Woodchopper and Sullivan Creeks has been done on deeply buried pay streaks that can only be reached by shafts, some of which are more than 100 feet deep.

Fineness of placer gold from Tofty area, Hot Springs district of Yukon region

\begin{tabular}{|c|c|c|c|}
\hline Creek & $\begin{array}{l}\text { Number } \\
\text { of records }\end{array}$ & $\begin{array}{l}\text { Range of } \\
\text { fineness }\end{array}$ & $\begin{array}{l}\text { Average } \\
\text { fineness }\end{array}$ \\
\hline $\begin{array}{l}\text { Cache } \\
\text { Sullivan } \\
\text { Dry } \\
\text { Woodchopper } \\
\text { Deep } \\
\text { American }\end{array}$ & $\begin{array}{r}2 \\
3 \\
2 \\
3 \\
2 \\
1 \\
14\end{array}$ & \begin{tabular}{|c|}
$8071 / 2-828$ \\
$807-821$ \\
$781-782$ \\
$8331 / 2-8561 / 4$ \\
$840-8411 / 2$ \\
$18281 / 2-873$
\end{tabular} & $\begin{array}{r}818 \\
813 \\
781 \\
843 \\
841 \\
1852\end{array}$ \\
\hline Total... & 26 & $\ldots$ & 838 \\
\hline
\end{tabular}

1 One record of $7891 / 4$ disregarded, as low total of silver and gold (976) indicated that it was of doubtfu 1 accuracy.

\section{IDITAROD DISTRICT}

The Iditarod district in the western part of the Yukon region embraces several placer mining camps that are supplied mainly from the settlement of Flat, which is reached by road from a point near the head of boat navigation on Iditarod River. The district has been one of the largest producers of placer gold in the entire Yukon region, being second only to the Fairbanks district. The most complete statement regarding the geology and mineral resources of this district is that by Mertie and Harrington. ${ }^{31}$ As that report was issued a number of years ago, a more recent statement regarding the mining work in the Iditarod district, as well as in nearby districts, should also be con-

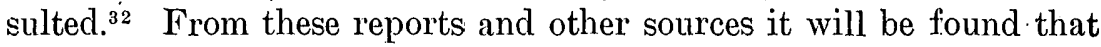
the productive camps of the Iditarod district all lie near the western margin of a large northeastward-trending belt of sedimentary rocks, dominantly of Upper Cretaceous age, that extend southwestward and eastward into the Kuskokwim Valley and northeastward into the Yukon Valley from the Ruby district to the Hot Springs district. The mineralization that afforded the valuable placer material appears to have been introduced by the granitic intrusive rocks that cut these Cretaceous beds. The mineralization was rather closely localized in the contact zones between these two different kinds of rock.

As is shown by the table, the gold of the Iditarod district is on the whole of moderately high fineness, as about 70 percent of the available records show fineness of more than 850 . None of the records, however, show gold higher than 891 fine. In order that the differences in the

\$1 Mertie, J. B., Jr., and Harrington, G. L., The Ruby-Kuskokwim region, Alaska: U. S. Geol. Survey Bull. 754, pp. 109-115, 1924.

${ }^{3}$ Mertie, J. B., Jr., Mineral deposits of the Ruby-Kuskokwim region, Alaska: U. S. Geol. Survey Bull. 864-C, pp. 198-224 (portion dealing specifically with Iditarod district), 1936. $252006-41-5$ 
fineness of the gold from different parts of the district may be set forth in somewhat fuller detail, the records have been grouped into three areas that have been designated from the main stream to which they are tributary the Otter, Willow, and Bonanza areas.

\section{OTTER AREA}

Otter Creek, a tributary of Iditarod River, joins the Iditarod about 8 miles in an air line upstream from the old settlement of Iditarod, which was situated at the head of ordinary river navigation. The principal settlement in the region is Flat, which is on Otter Creek about 8 miles due east of its mouth. Practically all the productive placer mining in this area lies within a radius of 5 miles of Flat in the valley of Otter Creek and its tributaries Flat and Slate Creeks. Mineralization seems to have taken place in the contact zones surrounding the larger granitic mass at the head of Flat Creek and the two smaller masses that crop out to the north of Otter Creek between Granite and Boulder Creeks, and in the valley of Cottonwood Creek. That the mineralization has a distinctly local distribution is indicated by the fact that the known valuable placers are closely restricted to those areas in which the intrusive rocks have been found. The fact that the gold of these placers has not been transported far is also indicated by the physical character of much of the gold. It should be realized, however, that the valley of Otter Creek has been subjected to numerous physiographic episodes whereby certain of its deposits now occur as benches high above the present drainage courses, whereas others are buried under gravel and outwash that has accumulated above them since their formation. Under these conditions, it is evident that the gold contained in them may show varierl characteristics dependent on the particular processes to which it has been subjected.

In the table on page 158 it has been shown that the 91 records from this area had a range of fineness of 822 to 891 . Of these, the 47 determinations made of gold from the valley of Otter Creek proper showed an average of 847 , whereas the 23 records from its tributary Flat Creek showed an average of 864, and the 14 records from Granite Creek showed an average of 854. Just west or downstream from Granite Creek is a small gulch known locally as Malamute Pup, the southern part of whose valley is carved in granitic rocks that give place farther upstream to slates and greenstones. Seven determinations of the gold from the placers of this valley give an average fineness of 832. It seems evident from the general geology in the environs of Malamute Gulch that the gold in the placers is of extremely local origin though the fineness would suggest a contrary conclusion. Possibly the reconciliation of these apparently conflict- 
ing lines of evidence is that the gold in the veins and stringers is of higher fineness than that of many of the specimens of locle gold from producing Alaska lode mines.

\section{WILLOW AREA}

Heading in the granitic mass at the head of Flat Creek, already described, but flowing in general westward, is Willow Creek and its tributary Happy Creek. Twenty-three determinations of the fineness of gold from Willow Creek and seven from Happy Creek show averages of 874 and 862 , respectively. The gold from Willow Creek: proper is described by Mertie as usually occurring in small particles, the largest piece of which he had record weighing less than half an ounce, whereas the gold from Happy Creek is said to be in coarsei! pieces. Mertie reported one nugget of $12 / 3$ ounces from the Happy Creek placer's. Although the records of the gold from Willow Creek show an average fineness somewhat higher than that for the placers in the valleys of the Otter Creek area to the north, the difference between the two seems too little to be of much moment, especially as residual placers between Willow Creek and the head of Flat Creek indicate that a part at least of the gold in the two valleys came from an identical source.

\section{BONANZA AREA}

Heading in the granitic mass at the head of Willow Creek and Flat Creek, already described, but flowing southward to join Bonanzi Creek, is the small stream known as Chicken Creek, from whose placers considerable gold has been mined. Fourteen determinations of the fineness of gold from the placer deposits on Chicken Creek show a range of 850 to 870 and an average of 861 . As would be expected from the similarity of environment of this valley to the Flat and Happy Creek Valleys to the north and west, the average fineness of the gold from the three is practically identical. According to Mertie, most of the gold is in small particles, which are rather angular and equidimensioniil. Nuggets are uncommon; Mertie states that the largest found up to the time of his visit in 1933 weighed less than half an ounce.

\section{INNOKO DISTRICT}

Lying northeast of the Iditarod district and southwest of the Ruby district, and adjoining on the west the McGrath area of the Kuskokwim region, is the Innoko district of the Yukon region. This district shows many of the same geologic features as the Iditarod district because the two lie on the same general bedrock formation. The sporadic distribution of the intrusive granitic masses, which in both districts seem to have been the centers around which the mineralization took 
place, has given rise to an irregular distribution of the gold-bearing piacers. These placers in the Innoko district, however, can be grouped into three principal areas, which are here described under the following names: Ophir, Tolstoi, and Cripple. The names refer to the principal settlements that now serve the areas, but the settlements themselves acquired their names from the streams in their neighborhood on which gold had been discovered prior to the establishment of the towns.

The general geology and mineral resources of the Innoko district, as well as of contiguous areas, have been described in a number of Geological Survey publications. The most complete report on the geology of the Innoko district is by Mertie and Harrington, ${ }^{33}$ but a more recent publication by Mertie ${ }^{34}$ gives some additional information and makes some revision of the earlier mapping and interpretations. The Innoko district has had the seventh largest output of placer gold of any district in the Yukon region. Much of the district is so remote and so difficult of access except by air that vast tracts of it are still practically unknown and only partly prospected.

As shown-in the table on page 158 , more than 50 percent of the available records of the Innoko district show fineness of gold in the 850-899 class, about 17 percent of the records show gold more than 900 fine, and none show fineness below 800 . There is, however, considerable variation in the fineness of the gold from the different areas in this district, which will be discussed in the description of each area.

\section{OPHIR AREA}

The Ophir area, which centers around the settlement of Ophir, on Innoko River, embraces several placer camps on streams that rise in the highlands within a radius of 10 to 15 miles of that town. The bedrock of the productive placer areas is sandstone and shale of Cretaceous age. In the vicinity of the known placers these sedimentary rocks are cut by many dikes of dacite and andesite, some of which are said to be mineralized, though Mertie feels that evidence of the relation of the mineralization to the intrusion of these dikes has not been thoroughly demonstrated. Certain of the streams, as for instance Ganes Creek, rise in the Beaver Mountain, the loftier parts of which are formed of a large intrusive mass of granite. Mertie states: ${ }^{35}$

It is possible that the country rock of the Ophir district is widely and diffusely mineralized both by small gold-bearing quartz veins and in mineralized zones where little or no quartz is present.

${ }^{33}$ Mertie, J. B., Jr., and Harrington, G. L., The Ruby-Kuskokwim region, Alaska : U. S. Geol. Survey Bull. 754, pp. 101-109, 1924.

B4 Mertie, J. B., Jr., Mineral deposits of the Ruby-Kuskokwim region, Alaska : U. S. Geol. Survey Bull. 864-C, pp. 115-245, 1936.

${ }^{85}$ Mertie, J. B., Jr., op. cit., p. 175. 
In the following table have been assembled the various available records from the individual creeks in the Ophir area. The creeks have been arranged from north to south in the order in which they join the main river.

Fineness of placer gold from ophiv area, Innoko district of Yukon region

\begin{tabular}{|c|c|c|c|}
\hline Creek & $\begin{array}{l}\text { Number } \\
\text { of records }\end{array}$ & $\begin{array}{l}\text { Range of } \\
\text { fineness }\end{array}$ & $\begin{array}{l}\text { A verage } \\
\text { fineness }\end{array}$ \\
\hline $\begin{array}{l}\text { Ophir } \\
\text { Spruce } \\
\text { Victor Gulch } \\
\text { Little-s } \\
\text { Ganes } \\
\text { Spaudding } \\
\text { Yankee }\end{array}$ & $\begin{array}{r}9 \\
1 \\
2 \\
9 \\
16 \\
1 \\
6\end{array}$ & $\begin{array}{r}883-9101 / 2 \\
8791 / 4 \\
8801 / 2-881 \\
825114-8371 / 4 \\
18171 / 4-8741 / 2 \\
857 \\
8661 / 4-886\end{array}$ & $\begin{array}{r}898 \\
878 \\
881 \\
830 \\
1846 \\
857 \\
882\end{array}$ \\
\hline Total & 34 & - & 865 \\
\hline
\end{tabular}

1 Some gold from Little Creek included in these records.

As is readily apparent, the gold from Ophir Creek has an average fineness somewhat higher than that from any of the other valleys. The gold from Spruce Creek and Victor Gulch shows little difference in fineness from that on Yankee Creek, which is much nearer the head of Innoko River. The average of the gold from Little Creek is lower than that from any of the other creeks, which is surprising, for the geologic environment of its valley seems to differ but slightly from that of Ophir or Spruce Creeks. The record of the gold from Ganes Creek probably does not correctly represent the true average fineness of the gold from that valley, for three of the six records used included some gold from Little Creek. It is probably due to the inclusions of some of this gold of low fineness that the average from Ganes Creek is so low because two of the records that are known to relate solely to gold from that valley show 874 and $8741 / 2$. It was unexpected that the gold from Ganes Creek should be even as high in fineness as that from the other creeks, because it is the only one of the streams discussed that heads back into the granitic mass of the Beaver Mountains. This seems to bear out the suggestion that the source of the deposits feeding the placers on Ganes, like those on the other nearby streams, was distinctly local in the Cretaceous sedimentary rocks and not closely related to the large granitic intrusive mass.

\section{TOLSTOI AREA}

The settlement of Tolstoi is on Tolstoi Creek, a tributary of Innoko River, some 25 miles in an air line northwest of Ophir. At one time quite a little placer mining was in progress in its environs, but lately it has dwindled until now only a few small camps are maintained in the area. The only records available to the Geological Survey as to the 
fineness of gold from this area are three from Esperanto Creek, which is about 10 miles northeast of Tolstoi. These show gold ranging in fineness from 860 to 878 , with an average of 869 . The geology in this area differs markedly from that prevailing throughout much of the rest of the Innoko district. East of Tolstoi is a considerable tract of undifferentiated metamorphic rocks consisting of schists, limestones, phyllites, quartzites, cherts, and greenstones. These evidently include rocks of various ages whose detailed relations have not been determined, so that they are grouped together and regarded as probably formed not later than the early part of the Paleozoic era. These rocks are apparently overlain by undifferentiated limestones that are believed to belong to the early Paleozoic. Both the limestones and schists have been intruded by basic igneous rocks of greenstone habit that are correlated with the late Paleozoic. At a later time Cretaceous sediments representing members of both the upper and lower series of this rock were deposited, and still later all these varied rock units were cut by granitic rocks of quartz diorite and of quartz monzonite composition. This is the complex setting in which the placers of the 'Tolstoi area occur, and until much more intensive study is made it is impossible to offer any adequate explanation of the details of their relationships. The moderately high fineness of the gold from Esperanto Creek suggests that the gold has had considerable transportation and is not of distinctly local origin. This cannot, however, be regarded as more than a surmise, and it is entirely possible that the centers of mineralization from which the placers were supplied afforded gold perhaps higher in fineness than is characteristic of some of the known gold lodes in other parts of Alaska.

\section{CRIPPLE AREA}

The settlement of Cripple is some 30 miles north and a little east of Ophir. The principal streams in whose valleys productive placers have been mined rise some 15 miles east of the town in the highlands known as the Cripple Creek Mountains. The central part of these mountains is a mass of intrusive acidic igneous rock that cuts the shales and sandstones of Upper Cretaceous age, as well as some older rocks of greenstone habit. The Cretaceous rocks are correlated with similar rocks in the Ophir area and with those in the mineral-bearing areas of the Iditarod district. Several placer mines have been developed in the valleys of the streams in the Cripple area, but the only one for which records of the fineness of the placer gold is available is Cripple Creek. Five determinations of the gold from placers in the valley of that stream show a range of 899 to $917^{1 / 4}$ with an average of 908 . Much more detailed work should be done before an attempt to interpret the geology of the area is justified. 
Even the general course of some of the streams is not known, so that topographic as well as geologic surveying is required. The extremely high fineness of the gold from Cripple Creek presents an apparently anomalous condition if the placers have derived their gold from local sources. Here, as in some of the areas where Tertiary granitic intrusions may have introduced the valuable minerals, a possible explanation of the high fineness of gold in the placers is due to the originally high fineness of the gold in the lodes and veins rather than to subsequent beneficiation through processes of weathering and transportation.

\section{KANTISHNA DISTRICT}

In central Alaska and in the southern part of the Yukon region along the lower foothills to the north of the Alaska Range is the Kantishna district, which has long been known to contain placers and lodes that have been successfully mined. The geology of this district has been described in a number of reports published by the Geological Survey, but the most recent statements are by Moffit ${ }^{36}$ and Wells. ${ }^{37}$ From these reports it may be learned that in general the bedrock in the vicinity of the placer areas is highly metamorphic schists belonging to the Birch Creek schist. In a few places these schists have been intruded by granitic rocks, which in the vicinity of the placers show but small surface exposures but in the more remote parts of the field form very large masses and probably underlie much of the district at a moderate depth. The schists are cut by innumerable veins and stringers of quartz, some of which show metallic mineralization that has been sufficient to encourage their being developed as lodes.

Most of the placer mining in the past has centered more or less closely around the old settlement Kantishna, on Moose Creek, which is tributary to Bearpaw River and then to Kantishna River. At one time a score of camps were mining on various creeks within 8 to 10 miles of this settlement, but of late years activities have dwindled greatly. Twenty-five miles northeast of the old settlement of Kantishna a small amount of placer mining has been done on Crooked Creek and its tributaries. Crooked Creek flows into Toklat River. In view of the geographic separation of these two tracts and of certain differences recognized in the gold from their placers, they have been discussed in the following pages separately under the respective headings Kantishna and vicinity and Toklat area. In general all gold from the Kantishna district belongs among that having extremely low

\footnotetext{
${ }^{30}$ Moffit, F. H., The Kantishna district, Alaska: U. S. Geol. Survey Bull. 836, pp. 301, $338,1933$.

${ }^{37}$ Wells, F. G., Lode deposits of Eureka and vicinity, Kantishna district, Alaska : U. S. Geol. Survey Bull. 849-F, pp. 335-338, 1933.
} 
fineness, and according to the records that have been examined the gold from the Toklat area is lower than that from any other placer camp in Alaska.

\section{KANTISHNA AND VICINITY}

As has been stated, mineralization apparently took place throughout the area adjacent to the old settlement of Kantishna at a number of different times in the long stretch of time that has elapsed since the old sediments that now form the Birch Creek schist were laid down. There is every reason to believe that the gold in the placers on the different streams is of exceedingly local origin and has not been transported far. It is true that part of the area lay within that occupied by the great expanse of ice in Pleistocene time, but it was close to the border of those glaciers, where erosion was relatively weak. As a result, the material that had been disintegrated and partly sorted was not widely dispersed or removed by the ice but underwent some further concentration by the floods of water flowing from the glaciers as they warcel.

Much of the gold from the creek placers of the Kantishna area is rough and angular, as though it had not been transported far. Many of the nuggets still have quartz adhering to them, showing that they had moved little from the present ledge, in which they had their origin. Of the 18 records from this area that were available for study, only 5 showed gold more than 800 fine and only 4 were less than 750 . In other words, half the records showed fineness between 750 and 800 , and the mathematical mean of the 18 records is 792 . The erratic quality shown by the records even of the same creek suggest either the possibility of faulty determinations or a great variation in the original composition of the gold in the veins from which the placer gold came. For instance, according to these records, the fineness of gold from Eureka Creek, a stream less than 4 miles long, ranges from $7303 / 4$ to 860 . There seems to be little reason to discredit the accuracy of the determinations, as they were made by at least three different agencies, each of which made some of the high as well as some of the low records.

TOKLAT AREA

Twenty miles or so to the northeast of the principal placer camps in the vicinity of the old settlement of Kantishna there has been in the past a small amount of placer mining in the valleys of some of the streams tributary to Toklat River. The fineness of the gold from certain of these deposits differs so markedly from that of any of the other gold from the Kantishna district, as well as from that from any of the other Alaska placer camps, that the area from which the gold is derived deserves special mention. The bedrock of the Toklat area is dominantly a member of the old pre-Cambrian Birch 
Creek schist. In the isolated hill between the Clearwater Fork and the main Toklat River, east of the mouth of Little Moose Creek, the schists are intruded by a granitic mass some 2 miles in diameter. The principal creek for which records of the fineness of placers are available is Little Moose. Six records of the fineness of gold from this creek, as reported by the operators, showed extreme range from $5631 / 2$ to 569 and an average of 566 . Wimmler, ${ }^{38}$ however, reports that he obtained a record from this creek that showed some gold that was only 550 fine. A few miles to the north of the placers on Little Moose Creek are other placers on Crooked Creek that show gold of more usual character. The only record available of the gold from Crooked Creek shows a fineness of 8421/2. No satisfactory explanation can as yet be advanced for the extraordinarily low fineness of the gold from Little Moose Creek. That the bedrock of the area has been extensively mineralized in places has been abundantly demonstrated. Some of this mineralization has resulted in the formation of workable lodes as is proved by the occurrence of the wellknown body of antimony ore on Stampede Creek, some 2 miles east of the placers on Little Moose Creek. Capps ${ }^{39}$ describes the gold from the valley of this stream as coarse and not greatly worn. Most of the gold is in moderately large pieces as compared with the usual run of placer gold, but large nuggets are uncommon and few have been found that weigh as much as an ounce.

\section{KOYUKUK DISTRICT}

The valley of Koyukuk River embraces about half of the Yukon, region north of the Yukon River in the part of its course between the international boundary and Nulato. Placer deposits have-been found at a number of widely separated places in this vast domain, but unfortunately the detailed records of the fineness of the gold from many of these deposits are not now available to the Geological Survey. The only records that have been included in the present study pertain to deposits in the northern part of the Koyukuk district that centers more or less closely within a score of miles of the settlement of Wiseman. Part of this area on the east abuts on the placer area near North Fork of Chandalar River in the Chandalar district.

\section{WISEMAN AREA}

The greater part of the Koyukuk district has been surveyed either not at all or in only the most sketchy manner. Even that part of the district containing the best-proven of the placer fields, near Wiseman, has been examined with a degree of thoroughness that is adequate only

\footnotetext{
\& Wimmler, N. L., Placer-mining methods and costs in Alaska: U. S. Bur. Mines Bül. 259 , p. 219, 1927.

${ }^{8}$ Capps, S. R., The Kantishna region, Alaska: U. S. Geól. Survey Bull. 687, p. 93, 1919.
} 
for exploratory purposes. The most comprehensive general statement regarding this area was prepared by Maddren ${ }^{40}$ more than 25 years ago. Since the publication of his report many new developments have taken place in the area, and much new insight has been gained as to the geology of adjacent parts of Alaska through the surveys that have been carried on in nearby tracts. The Maddren report, therefore, should be thoroughly revised to bring it up to date and to refine the exploratory quality of the work to meet current, more detailed standards.

In general the bedrock in the Wiseman area consists of highly metamorphic schists, which have not been adequately differentiated but are among the older rocks of Alaska, perhaps even being pre-Cambrian in . age. To the north nearer the crest of the divide that separates the Koyukuk basin from the basins of streams flowing into the Arctic Ocean, these schists are succeeded by younger members of the Paleozoic sequence up to and including the Carboniferous. All these rocks, as. well as still younger sediments, are cut by granitic instrusives that probably were injected not earlier than Jurassic and some probably as late as Tertiary time. Mineralization in the schists is widespread, especially in the vicinity of the igneous intrusions. All of the sedimentary rocks, even those of Upper Cretaceous age that crop out in. nearby areas, have been intensely folded and subjected to severe mountain-building stresses.

Much of the country in the vicinity of the placers of the Wiseman. area has a rugged, mountainous topography, and in the relatively recent geologic past much of the area was glaciated, with streams of ice flowing down the principal valleys and profoundly modifying the existing topography. Then with the retreat and almost entire disappearance of glaciers even in the highest parts of the Brooks Range a flood of detritus was spread out over the country by the waters from the melting ice, loaded with the rocks and material that the glaciers had eroded from their valleys in their advance. Many of the small. side stream valleys escaped severe scouring by the glaciers, and in them. some of the old placers were preserved. In other places where the glacial erosion was more severe, the present stream placers probably represent earlier disintegrated material that has been reworked several. times by successive agencies of erosion.

The available records of the gold from the Wiseman area show that most of the gold from its placers is of unusual purity. Of the 18 available records, only 2 show a fineness of less than 950 , and they are 925 . and $9401 / 4$. The highest record from the district is that reported by Wimmler ${ }^{41}$ as $9781 / 2$, but the highest in the records received by the

\footnotetext{
${ }^{40}$ Maddren, A. G., The Koyukuk-Chandalar region, Alaska: U, S. Geol. Survey Bull, 532, pp. $83-110,1913$.

41 Wimmler, N. L., op. cit., p. 219.
} 
Geological Survey direct from the operators is 971 . The average fineness shown by the 18 records that have been tabulated by the Survey is 958, which stands as the highest average for any of the Alaska areas. This high average is all the more surprising when it is remembered that the gold from many of the placers is rough and irregular, as though it had not been transported far; and many nuggets have been found with fragments of quartz from the vein in which the material originated still adhering to them. The gold on which the foregoing records are based came from Hammond River, Nolan, Smith, Archibald, Fay, Vermont, and Swift Creeks, which are tributaries of the Middle Fork of Koyukuk River; Lake Creek, which is a tributary of Bettles River; and Spring Creek, which is a tributary of Wild River.

\section{MARSHALL DISTRICT}

The Marshall district is the westernmost placer camp of the Yukon region. It takes its name from the small setflement on the Yukon River, but as the term is used by the Geological Survey it has been extended to cover almost all that part of the country north of the Yukon River between Marshall and Anvik, some 70 miles to the northeast. Very little of this vast tract of country has been explored even in the most casual fashion, and thousands of square miles in it are entirely unmapped. The best general description of the tracts that have been examined in any detail is that by Harrington. ${ }^{42}$ From that report it is learned that the oldest bedrock formation recognized in the district is a series of shales and other sediments associated with greenstones, the whole assemblage being regarded as late Carboniferous. Overlying these are argillites, sandstones, and conglomerates that are dominantly of Cretaceous age. There are also large areas formed of flows of lava that ranges in composition from andesitic to basaltic, and in age from late Cretaceous to late Tertiary or even Quaternary. A part of the Upper Cretaceous rocks and all the earlier: rocks have been intruded by granitic rocks of soda granitic, quartz dioritic, and dioritic composition. These intrusive masses are known at a number of points within a radius of 20 miles of Marshall, and one such mass occurs on Anvik River some 25 miles northwest of Anvik. Doubtless many other masses would be found if the region were thoroughly explored and if the extensive deposits of Quaternary alluvium were removed.

For convenience of description in this report the known placer deposits of the Marshall district have been assigned to three small areas called the Fortuna, Kako, and Stuyahok areas. The Fortuna area, named from the old post office of Fortuna Ledge, embraces all the western part of the district that centers around the settlement of

\footnotetext{
${ }^{42}$ Harrington, G. L., The Anvik-Andreafski region, Alaska: U. S. Geol. Survey Bull. 683, pp. 22-63, 1918.
} 
Marshall. The Kako area is so called from the small stream that traverses it. It lies a short distance north of the settlement of Russian Mission and is about 25 miles due east of Marshall. The Stuyahok area takes its name from the large northward-flowing stream called Stuyahok River, a tributary of Bonasila River, which in turn flows into the Yukon River some 12 to 15 miles south (downstream) from Anvik.

\section{FORTUNA AREA}

Although in the past mining was active in many of the valleys of the Fortuna area, it has dwindled until in the last few years only a few small camps have been in operation. As a result the Geological Survey has only a few records of the fineness of gold from this area, and these apply only to two creeks, Willow and Elephant Creeks. The record of the gold from these deposits, however, seems to be remarkably consistent in that the greatest range of fineness shown is from $8713 / 4$ to $883 \frac{1}{2}$, with an average of 880 . The gold from the Willow Creek Valley is described by Harrington as rough and rather porous. He further states that over half of the gold recovered in the course of a clean-up is in such large particles that it will not pass through an 8-mesh screen. Although small nuggets are common, it is rare that pieces weighing more than half an ounce are found. Possibly the absence of much gold in small particles may be due to the lack of adequate gold-saving devices in the washing plants employed. A few grains of platinum are said to occur in the concentrates resulting from the gold-mining operations.

\section{KAKO AREA}

Very little is known about the bedrock geology of the Kako area. From the observations made at the bluffs of the Yukon near the mouth of the stream, it seems that the southern part of this valley has been cut mainly in rocks of the old greenstone sequence, and that probably farther upstream these rocks give place to members of the Upper Cretaceous sequence. No intrusive rocks are known to occur in the area, but this by no means indicates that they do not occur, as nothing is known of the geology for more than a few miles back from the Yukon. Only five determinations of the fineness of gold from this area are available at this time. These show a range of 813 to 822 and an average fineness of 818 . It would be expected that the fineness of gold from the Kako and Fortuna areas would be closely similar in view of the apparent likeness of the recognized geologic features of the two. The wide difference, however, between an average fineness of 880 in the Fortuna area and 818 in the Kako area clearly emphasizes the fact that unexplained differences still remain for the geologist to decipher. His determinations may aid the prospector 
in his search for other areas that hold promise of containing workable deposits.

\section{STUYAHOK AREA}

The parts of the Stuyahok Valley that have been examined by geologists of the Geological Survey seem to have for their bedrock exclusively andesitic and dacitic lava flows and dikes, which are sparingly associated with some minor amounts of sedimentary rocks. None of the greenstone and related rocks of the other areas in the Marshall district have been recognized in this area. Only two records of the fineness of placer gold in the Stuyahok area are now available to the Geological Survey. These records show a high of $8021 / 4$ and a low of 772 , or an average of 787 . The small number of records available for consideration necessarily raises some doubt as to how truly representative the records are and how much reliance should be placed on them. In spite of this doubt it is believed that these records are indicative of the probable conditions and strongly suggest that the gold from this area will be found to differ markedly from that in the Fortuna area and may prove to be different also from that in the Kako area. No satisfactory reason for this difference can be advanced, but if the difference proves to be real it would seem more likely that the original gold in the veins or lodes supplying placers in the Stuyahok area was of lower fineness than that supplying the other areas rather than that it had undergone less transportation and was nearer its original source.

\section{RAMPART DISTRICT}

\section{MINOOK AREA}

Lying south of the Yukon River, west of the Tolorana district, and north of the Hot Springs district is the Rampart district, which takes its name from that of the principal town that serves as a center for the miners in the surrounding camps. A few years ago a number of placer camps actively operated at remote points in the Rampart district but at the present time practically the only placer mining in progress during the open season is in the valley of Minook Creek and its tributaries. This area will be referred to as the Minook area, to differentiate it from the Troublesome Creek area, which lies some distance east of Rampart, or the Morelock Creek area, which lies to the north of the Yukon River some 35 miles west and a little south of Rampart. No records of the fineness of gold from any of the nreas except the Minook area have been available, and consequently those other areas will not be treated in this report.

The general geology of parts of the Rampart district have been described by several Survey geologists, but the most recent comprehen- 
sive report is that by Mertie, ${ }^{43}$ which also describes parts of the Hot Springs district. This district was earlier described by Eakin, ${ }^{44}$ but Mertie $^{45}$ later revised that work, as well as his own work, in his description of the general features of the whole Yukon-Tanana region, of which the Rampart district is a part. According to these reports, the bedrock throughout much of the Rampart district consists of various sedimentary rocks of the Carboniferous system overlaid to the south by Cretaceous beds. Intrusions of granitic rocks of Tertiary age occur in places in the highlands that separate the streams of the Minook area from those in the Hot Springs district, as already noted. These intrusions seem to have been influential in the introduction of mineralization in their environs. Glaciation has not directly affected the area. The area has undergone great physiographic changes in the Tertiary and succeeding epochs, as is shown by high terrace gravels 1,000 feet or so above the present level of the Yukon, lower bench deposits at many places and buried placers below the present drainage lines.

As shown by the record for the district in the table on page 159 , all the placer gold from the area has high fineness-the 20 available records all showing gold over 900 fine. One lot of gold reported by Wimmler ${ }^{46}$ from Little Minook Creek is said to have been 975 fine, but this is nearly 35 points higher than any shown by the other available records from this creek and is 43 points higher than the average for the entire district, even including this high record. Considerable variation has been noted in the physical character of the gold from different valleys and even from different parts of the same valley. On the whole, however, much of the gold appears to be well worn and smooth, though rough gold is by no means rare. Little of the gold is flaky, even though it has been considerably flattened. Nuggets weighing as much as an ounce are fairly common, and some weighing . as much as 10 ounces or more have been found on Hunter and Little Minook Creeks. The high fineness of gold from this area is in striking contrast to the low fineness of most of the gold from the Eureka area, which lies immediately to the south and not more than 15 to 20 miles distant. As previously stated, the average fineness of the gold from the Eureka area, shown by the records used in this report, was below 800 , as contrasted with a fineness of about 930 for the gold from the Minook area. No satisfactory explanation of the difference can be given.

${ }^{43}$ Mertie. .T. B., Jr., op. cit. (Bull. 844-C), pp. 163-226, 1934

.4 Eakin, H. M., A geologic reconnaissance of a part of the Rampart quadrangle, Alaska : U. S. Geol. Survey Bull. 535, 38 pp., 1913.

${ }_{45}$ Mertie. J. B., Jr., The Yukon-Tanana region, Alaska: U. S. Geol. Survey Bull. 872, 276 pp., 1937.

${ }^{40}$ Wimmler, N. L., op. cit., p. 219. 
Lying some 50 miles or more'southeast of Fairbanks is the Richardson district, a small placer area that for a number of years following the rush to Fairbanks had a considerable production of placer gold. Later mining in the district dwindled until now it is carried on at a much reduced scale. The geology and mineral resources of the Richardson district have been described by Prindle, ${ }^{47}$ and his investigations supplemented by those of later geologists who have visited the camp have been utilized by Mertie ${ }^{48}$ in his mapping and general description of the whole Yukon-Tanana region. The bedrock of the district consists dominantly of highly metamorphic members of the Birch Creek schist, comparable in all respects with the rocks of the same group that occur in the Fairbanks, Hot Springs, Fortymile, and some of the other placer camps in the Yukon-Tanana region. Small quartz veins and stringers are common in the schists, and in some of them gold and other metallic minerals have been recognized. The small masses of granitic igneous rocks that intrude the schist at several points in the district were probably injected during late Mesozoic time or later. Much of the gold from the Richardson area is rough and rather heavily iron-stained, and particles of quartz adhere to some of the larger pieces. The district has experienced a complex series of geologic events during 'Tertiary time and later, but there is no evidence that it was ever subjected to glaciation.

The five records from the Richardson district received by the Geological Survey directly from the operators show a range in the fineness of gold of $6391 / 4$ to 785 , with an average of 741 . Wimmler, ${ }^{49}$ however, reported two other records of gold from this district-one from a placer near the head of Tenderfoot Creek of 640 and one from a placer near its mouth of 720 . The average of all seven of these records from the district is approximately 724 . The gold from the Richardson district is thus among the lowest of any from camps in the whole Yukon region.

\section{RUBY DISTRICT}

Midway along the course of the Yukon River between the mouths of Tanana and Koyukuk Rivers is the settlement of Ruby. Stretching southward from Ruby for a distance of nearly 50 miles is a tract, of country dotted at intervals by placer camps. This tract is sometimes referred to as the Ruby-Poorman district, but in this report, although embracing the same area, the entire district will be referred

\footnotetext{
${ }^{47}$ Frindle, L. M., Gold in the Tenderfoot region, Alaska: U. S. Geol. Survey Bull. 525, pp. 140-142, 1913.

${ }^{48}$ Mertie, J. B., Jr., op. cit. (Bull. 872).

${ }^{40}$ Wimmler. N. L., op. cit., p. 219.
} 
to simply as the Ruby district. The known placer deposits in the entire northern part of the district are in the valleys of streams tributary to Sulatna River, which joins the Yukon some distance east (upstream) from Ruby. The known placer deposits in the southem part of the area all cluster around the settlement of Poorman or are in the valleys of streams tributary to Poorman Creek, which flows westward to join the North Fork of Innoko River. These two areas have, for convenience, been designated, respectively, the Sulatna and Poorman areas of the Ruby district.

The general geology of the Ruby district has been described by a number of Survey geologists, but the most comprehensive and the latest reports on the district are those by Mertie. ${ }^{50}$

The bedrock throughout the areas in which productive placers have been found consists of highly metamorphic schistose rocks of early Paleozoic or pre-Paleozoic age and greenstone lavas and tuffs that have been much deformed and sheared and are probably of late Paleozoic age. Here and there cutting these rocks and probably of Mesozoic age are granitic rocks. The mineralization which introduced the valuable metals later concentrated in the placers is believed to have been attendant on the intrusion and consolidation of these igneous rocks. There are no signs that any part of the district has ever supported glaciers. Some Cretaceous sedimentary rocks occur in the southern part of the area at the head of Glacier Creek and not far from the divide at the head of Tamarack Creek and to the south of Poorman. Small patches of 'Tertiary basaltic lava have been mapped to the west of Spruce Creek and to the northwest of Poorman. These late lavas do not seem to have had any marked effect on the presence or absence of the placers.

\section{SULATNA AREA}

The placer deposits of the Sulatna area are distributed in the valleys of a number of streams that head in a more or less distinct northward-trending ridge lying between the middle and upper portions of the course of Sulatna River. Mertie states that the gold placers in general are deeply buried discontinuous bodies of gravel that are covered with silt and occur in rather wide, open valleys. Most of the gold is said to be rather irregular in outline and rather rough, as though it had not been moved far from its bedrock source.

The 28 records of the fineness of gold from this area indicate an average of about 857 , but as there is considerable variation in the fineness of gold from the individual creeks, the records have been given separately in the following table:

\footnotetext{
Bo Mertie, J. B., Jr., op. cit. (Bull. 864-C), pp. 115-247. Mertie, J. B., Jr., and Harrington, G. I., op. cit. (Bull. 754$), 129 \mathrm{pp}$.
} 
Fineness of placer gold from Sulatua area, Ruby district, of Yulion region

\begin{tabular}{|c|c|c|c|}
\hline Creek & $\begin{array}{l}\text { Number } \\
\text { of records }\end{array}$ & $\begin{array}{l}\text { Range of } \\
\text { fineness }\end{array}$ & $\begin{array}{l}\text { Average } \\
\text { fineness }\end{array}$ \\
\hline $\begin{array}{l}\text { Granite. } \\
\text { Trail } \\
\text { Tamarack } \\
\text { Spruce } \\
\text { Greenstone } \\
\text { Long } \\
\text { Fot } \\
\text { Bear. }\end{array}$ & $\begin{array}{l}1 \\
3 \\
4 \\
3 \\
8 \\
6 \\
2 \\
1\end{array}$ & $\begin{array}{l}9061 / 2 \\
8303 / 4-838 \\
852-871 \\
851 \\
8641 / 2871 / 2 \\
8531 / 2-8811 / 2 \\
786-797 \\
858\end{array}$ & $\begin{array}{l}906 \\
835 \\
859 \\
864 \\
868 \\
866 \\
792 \\
858\end{array}$ \\
\hline Total. & 28 & $\ldots$ & 857 \\
\hline
\end{tabular}

The order of arrangement of the creeks in the preceding table has been to give the first place to the stream that is tributary to Sulatna River farthest to the north (downstream), and then follow successively with those that join the river farther upstream. The extremely crooked course of Sulatna River is such, however, that Granite Creek, which is first in the list, heads within a few miles of Bear Creek, the last of the list, though the distance measured along the stream between the two is many scores of miles. As is evident from the table, almost all the records, except those from Granite and Flat Creeks, depart little from the average for the area. Granite Creek derives most of its gravel and placer material from the granite mass at its head or from the schists that are in close proximity to that mass. The high fineness of the gold from the valley of that stream is therefore unexpected, unless it is assumed that in its original bedrock source the gold was of much greater purity than is customary for vein or lode gold. The low fineness of the gold from Flat Creek is equally unexpected, and no adequate reason can be advanced at this time as to why it should differ so markedly from that from other nearby tributaries of Long Creek. Mertie describes the gold from Flat Creek as coming from beneath permanently frozen ground. It is rough and occurs mainly in the upper 6 inches of bedrock or on the bedrock surface, usually mixed with much broken vein quartz. Few large pieces of gold have been found-the largest reported by Mertie weighing about half an ounce.

\section{POORMAN AREA}

Although the bedrock geology of the Poorman area is in the main similar in its general features to that of the Ruby district as a whole, already described, there are certain notable differences. The Poorman area lies near the extreme southern limits of the tract in which the old highly metamorphic schists crop out. In all the region to the south and southwest the country rock consists of members of the younger formations, including chert, argillite, and interbedded rhyolitic tuff, which are provisionally assigned to the Mesozoic; and sandstones, shales, grits, and conglomerates that are correlated with rocks at least 
as old as the Cretaceous. Mertie regards the gold in the placers in the vicinity of Poorman, however, as having originated in the quartz veins in the metamorphic rocks of the neighborhood and he assumes that not far beneath the surface there are bodies of granitic rocks that produced the mineralization. In general, the gold shows few signs of having been carried far from its point of origin, as it is rough .and little worn.

The 21 records of the fineness of gold from this area show gold of a somowhat lower quality than that from the nearby part of the Sulatna area. The difference, however, is not great, as at least 18 of the records show gold that averages about 837. The gold from Timber Creek, however, is of much lower grade, the three determinations of gold from that creek showing an average of only 785. The extremely low fineness of this gold recalls the records of the gold from Flat Creek in the Sulatna district, which averaged about the same, or 789 fine. 'There is, however, no obvious basis for considering that there is any other close relation between the gold from the two creeks for the two streams are more than 20 miles distant from each other, and numerous other streams that do not afford gold of low fineness lie. between the two.

The following table lists the principal streams in the Poorman area for which there are records available in the Geological Survey as to the fineness of the gold found in their placers.

Fineness of placer gold from Poorman area, Ruby district, of Yukon region

\begin{tabular}{|c|c|c|c|}
\hline Creek & $\begin{array}{l}\text { Number } \\
\text { of records }\end{array}$ & $\begin{array}{l}\text { Range of } \\
\text { fineness }\end{array}$ & $\begin{array}{l}\text { A verage } \\
\text { fineness }\end{array}$ \\
\hline $\begin{array}{l}\text { Poorman } \\
\text { Timber } \\
\text { Moose } \\
\text { Solomon.... }\end{array}$ & $\begin{array}{l}9 \\
3 \\
7 \\
2\end{array}$ & $\begin{array}{l}829-8531 / 2 \\
7791 / 2-793 \\
8361 / 4-845 \\
830-835\end{array}$ & $\begin{array}{l}839 \\
785 \\
839 \\
832\end{array}$ \\
\hline Total... & 21 & - n. & 83 \\
\hline
\end{tabular}

TOLOVANA DISTRICT

The Tolovana district includes much of the country lying 50 miles or so to the north and northwest of Fairbanks. It takes its name from. Tolovana River, to which most of the streams on which placer mining has been in progress recently are tributary. The town of Livengood, on Livengood Creek, is the principal settlement in the area, and practically all the individual placer camps lie within a radius of 10 to 15 miles of the town. The geology of the district has been described in some detail by Mertie. ${ }^{51}$ Some of the interpretations of the geology thus presented were later reconsidered and revised, where

${ }^{51}$ Mertie, J. B., Jr., The gold placers of the Tolovana district, Alaska: U. S. Geol. Survey Bull. 662, pp. 221-277, 1918. 
necessary, by Mr. Mertie ${ }^{52}$ in a general report on the whole YukonTanana region that thus includes the Tolovana district.

The bedrock throughout that part of the Tolovana district in which most of the placers occur are undifferentiated sedimentary rocks that probably were formed during the middle part of the Paleozoic and are succeeded by cherts and associated rocks that are regarded as Carboniferous. The small intrusion of granitic igneous rocks that crops out near the head of Amy Creek is doubtless the resistant rock that has caused Amy Dome to stand up above most of the surrounding country. The placers that have proved productive belong. to two distinct types-namely, creek placers and bench placers. The bench placers have proved much richer than those in the streams and have been mined mainly by drifting methods.

In the table on page 159 the Tolovana district has been subdivided into three separate areas, namely, the Livengood, Olive, and Wilbur areas. The separation into the Livengood and Olive areas was made largely because Olive Creek is a separate tributary of Tolovana River, entering that stream some 4 miles upstream from Livengood Creek. Inasmuch, however, as the two areas lie so close together and, so far as can be recognized, have the same general geologic conditions and gold of the same general fineness, it has seemed best to treat them together in the following notes.

\section{LIVENGOOD AND OLIVE AREAS}

According to Mertie, there is little doubt that the mineralization that produced the placers in the vicinity of Livengood was closely localized in the ridge between Livengood Creek and Tolovana River. The distribution of the placers, as well as the occurrence of intense mineralization in the lode deposits at the heads of Ruth, Lillian, and Olive Creeks, all point to this conclusion. The gold mineralization is related to the intrusion of igneous rocks in that area. Igneous rocks of varied types occur in the ridge in question, so that some uncertainty exists as to the relations of each type to the important mineralization. In spite of these uncertainties, Mertie concluded that the gold mineralization probably was most closely related genetically to the acidic intrusive rocks that occur in this ridge.

Mertie states that the gold from the placers in the different parts of the Livengood area differs much in color, shape, size, and porosity. Some of the gold is light golden yellow, whereas some is dark and ironstained; some is well-rounded but some is rough and angular. Both large and small particles of gold are found in the clean-ups from the same claim. While a good proportion of the gold is nuggety, even the larger pieces seldom weigh more than 2 ounces. In spite of the

s2 Mertie, J. B., Jr., op. cit. (Bull. 872). 
great variation in the appearance of the gold the records from the: different placers on the whole show rather uniform fineness. The range in fineness of gold from these areas is $8671 / 2$ to 932 , and if the one exceptionally low record of $8671 / 2$ is excluded from the 98 records. given the lowest limit becomes $8961 / 2$.

In the following table the various streams tributary to Livengood Creek are listed in the order in which they join the main creek from. south (downstream) to north (upstream); in other words, Lillian. Creek comes in nearest the mouth of Livengood Creek and Heine Creek comes in at the extreme head of that valley. Olive Creek, as already stated, is not a tributary of Livengood Creek but flows directly into Tolovana River.

Fineness of placer gold from Livengood and Olive areas, T'olovana district, of Yukon region

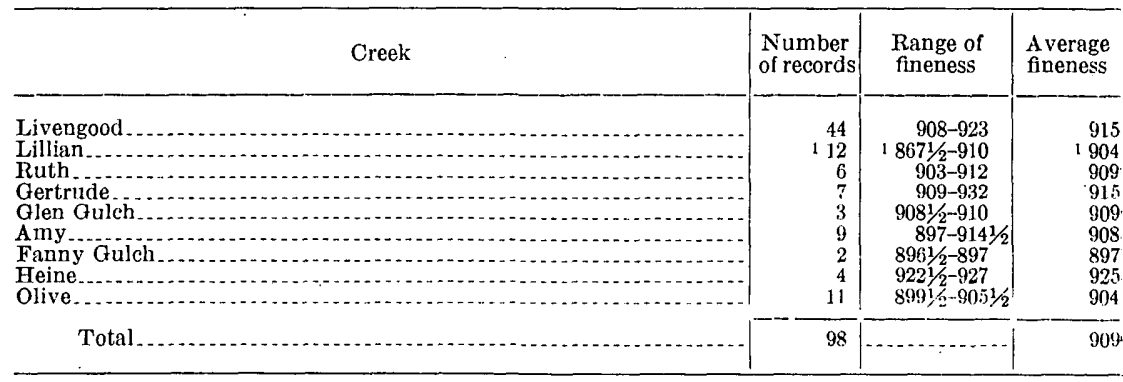

1 One record only below 900 .

As is evident, the fineness of gold from the valleys of these different streams does not show any regular progressive trend toward higher or lower grade. In fact, it is a striking fact that the highest average fineness is from the extreme headwater region (Heine Creek), whereas the lowest average fineness is also from an extreme headwater part of one of the side streams-Fanny Gulch, a tributary of Amy Creek. But even between these extremes there is a difference in the average fineness of only 28 points.

\section{WILBUR AREA}

Wilbur Creek is the only tributary of Tolovana River from the south in the valley of which placers have been mined and for which records of the fineness of the gold are available in the Geological Survey. These records are so at variance with all those from the other parts of the district that they have been segregated as indicating an entirely separate area. In the vicinity of Wilbur Creek, instead of the Carboniferous rocks that are dominant in the Livengood area, the bedrock consists entirely of members of the undifferentiated Paleozoic sedimentary rocks that are now regarded as mainly Devonian, with perhaps some Silurian beds as well. No granitic igneous. 
intrusions have been reported from the Wilbur area. The source of the deposits that supplied the gold found in the placers has not been determined but it is believed to be rather sharply localized, as indicated by the extremely restricted distribution of the known placers. The extremely low fineness of the gold from Wilbur Creek affords further evidence that points to the localization of the mineralization and suggests that the gold has not undergone much transportation from its bedrock source. The four records available to the Geological Survey show range of fineness of 772 to $7761 / 2$, with an average of 774 . The striking difference in the fineness of this gold and that from the Livengood-Olive area reminds one of a somewhat similar great difference between gold from the Minook area of the Rampart district, with an average fineness of about 930, and that from the Eureka area of the Hot Springs district, with an average fineness of 784 .

\section{KUSKOKWIM REGION}

Embracing all of western Alaska that lies south of the Yukon region and extending north and west from the crest of the Alaska Range to take in all of the watershed drained by Kuskokwim River is an enormous tract of country that is here called the Kuskokwim region. Much of this region is entirely unexplored, so that even general information regarding tens of thousands of square miles lying within its borders is lacking. In spite of the imperfection of the records regarding most of this region, several mining camps have been established at widely scattered points in it; all of these have been given at least cursory examinations by the geologists of the Geological Survey, and the results of those examinations have been published. The region, however, is so vast and presents such a variety of features that it is impracticable to make any brief generalizations that will describe it adequately as a whole. It has seemed desirable, therefore, to postpone discussion of the general geology of the region here and, instead, to summarize the geology of the smaller subdivisions in the later pages that are devoted to the districts and areas.

Many different criteria might be used in subdividing the Kuskokwim region into smaller units, but for purposes of this report, dealing as it does with placers, it has seemed expedient to make the subdivisions primarily in relation to the various known placer fields. On this ground four major districts have been distinguished-McKinley, Georgetown, Tuluksak-Aniak, and Goodnews districts. Each of these takes its name from some conspicuous natural feature, such as a mountain, river, or bay, as in the case of the first and last two districts, or from a settlement, as in the case of Georgetown. Each of these districts is still further subdivided into smaller areas, which will be described in some detail in later pages. 
As will be evident from the figures given in the summary table on pages $159-160$, some 72 records of the fineness of gold in the Kuskokwim region have been available to the writer for this study. These show a great range in the fineness of the gold from different camps. The highest recorded fineness is nearly 962 and the lowest 746 . Nearly 42 percent of the records are of gold at least 900 fine, about 31 percent. between 800 and 900 , and about 27 percent below 800 fine. As will be shown later, this great range of fineness, while true for the region. as a whole, does not obtain for the smaller subdivisions of it. Certain of these small areas have characteristically gold of high fineness, whereas others have gold of low fineness, and still others have gold of intermediate grade.

\section{MCKINLEY DISTRICT}

The eastern part of the Kuskokwim region forms what is here called the McKinley district. 'This, in a sense, is a misnomer, because none of the streams of the Kuskokwim drainage basin rise within many miles of Mount McKinley proper, though many of the tributaries from the south do rise in the southwesterly continuation of the mountain mass of which majestic Mount McKinley is the culminating peak. None of the productive placer camps occur in the vicinity of the high mountains in this portion of the district, but all lie within a radius of 40 to 50 miles of the settlement of McGrath, which is near the point where the general westerly trend of the headwater portion of Kuskokwim River changes rather abruptly to a more or less south-southwesterly course. These smaller tracts, in addition to the one near McGrath, are the Nixon Fork area, some 35 miles northeast of McGrath, and the Moore Creek area, which lies some 50 miles west-southwest of McGrath. The McGrath area adjoins the Innoko district of the Yukon region. Some of the operating mines in the Innoko district are not. more than 25 miles in an air line west of the settlement of McGrath.

The geology of the placer areas in the McKinley district have been examined at different times in the past by various geologists of the Geological Survey, and reports on their observations have been published. The latest of these is one by Mertie, which includes the results. not only of his own work in this field but revises and brings up-to-date all the earlier work of himself and others. This report, ${ }^{53}$ however, contains no geologic map of these areas, and his earlier report ${ }^{54}$ should. therefore be consulted for such information as can best be shown graphically by such an illustration.

39ertie, J. B., Jr., op. cit. (Bull. 864-C), pp. 115-235.

i. Mertie, J. B., Jr., and Harrington, G. L., op. cit. (Bull. 754). 


\section{NIXON FORK AREA}

The placer camps in the Nixon Fork area cluster around the highland area lying between the main Kuskokwim River and its large tributary from the north-Nixon Fork. The geology of this area has been fully described in the report by Brown, ${ }^{55}$ which is accompanied by a geologic map, and the report by Mertie, already referred to. Many different kinds of rocks of diverse ages crop out in the area, but in the vicinity of the placers the older members of the bedirock are principally limestones of middle Paleozoic age, including, according to the fossils they contain, representatives of the Ordovician, Silurian, and Devonian systems. In places near the higher parts of the upland, these older rocks are overlain by dark shales and impure sandstones that are not older than the Cretaceous. All these sedimentary beds have been intruded by stocks of quartz monzonite and granite, which show porphyritic border zones. The intrusive rocks are regarded as of Tertiary age. Mineralization has been strong enough in the contact zone near these instrusives to form lodes, some of which have been mined commercially. Mertie states that the intrusions were unquestionably the source of the mineral-bearing solutions that have produced the gold lodes of the area from which in time the gold in the placers has been derived.

The gold from the placers in different valleys in this area, even though the placers lie within a mile or two of each other, show wide variation in fineness. Of 17 determinations of the fineness of gold from Hidden Creek, all but one-8921/2 - showed gold of a fineness of $9111 / 2$ to $961 \frac{13}{4}$. The bedrock at most of the placers in this valley is largely monzonite. On Holmes Gulch, a tributary of Hidden Creek, whose valley has been cut mainly in the areas occupied by Paleozoic limestones, with some small patches of Cretaceous sandstones and shales near its head, the only available record shows gold 885 fine. Birch Creek that lies less than half a mile east of Holmes Gulch and whose valley is cut in Cretaceous sediments and contact metamorphic facies of the monzonite, according to Mertie, afforded gold 9613/4 fine. Riddle Gulch, an extreme headwater of Hidden Creek whose valley lies entirely within the area occupied by monzonite, afforded the two records of $8573 / 4$ and 886 . Ruby Creek heads near the same area as Riddle Gulch, and its placers are only half a mile distant from those on that gulch, but it flows westward to join Nixon Fork upstream from Hidden Creek. Only a single record of placer gold from Ruby Creek is avsilable, and it shows a fineness of only 8073/4. This great difference in fineness presents a baffling problem that has not been solved.

${ }^{65}$ Brown, J. S., The Nixon Fork country, Alaska: U. S. Geol. Survey Bull. 783, pp. $97-144,1926$. 


\section{MCGRATH AREA}

The only recent placer mining in the vicinity of McGrath has been on Candle Creek, a tributary of Tatalina River that joins the Kuskokwim a few miles north (upstream) from McGrath. The bedrock in the general vicinity of Candle Creek is dominantly sandstones, shales, and grits of the Cretaceous system, but to the east of the valley and south of McGrath are limestone and shale, with some fine-grained arkose, an assemblage of rocks regarded as of Devonian age. At the head of the Candle Creek Valley is an area of basalt that gives place toward the east to a mass of quartz monzonite some 4 miles in diameter. The placer gold is derived from small quartz veins in the monzonite and in the mineralized country rock adjacent to it. The time of the intrusion of the quartz monzonite has been definitely set as Tertiary, and it may have been as late in that era as some time after the end of the Eocene. All of the seven records of gold from these placers that were received direct from the operators, as well as the average of eight reports referred to by Mertie, ${ }^{56}$ show gold of high fineness. With the exception of one record of gold showing a fineness of $8941 / 2$, the reports show only a small range in fineness-912 to 917-and an average of 914. This is in rather marked contrast to the fineness of gold in the nearby Ophir area of the Innoko district, which averaged 865. The fineness of the gold from Candle Creek seems unusually high for placer gold that apparently is of such local origin. Like the gold of high fineness from the Nixon Fork area, it may possibly indicate that the gold in the stringers and veins that fed the placers was abnormally pure for lode gold.

\section{MOORE CREEK AREA}

Moore Creek is a tributary of Takotna. River that joins that stream not far from its head and perhaps 8 to 10 miles northeast of Camel Back Mountain. Many of the geologic features in the vicinity of Moore Creek resemble those in the productive placer areas of the Iditarod district, to the southwest, or of the Ophir area of the Innoko district, to the northeast. The southern or lower part of the Moore Creek Valley lies in an area of Cretaceous sediments, and the bedrock in its headward portion is pyroxene andesite, and basalt flows and tuffs that are of early Tertiary age. Along and near the contact zone between these two different kinds of rock is a more or less linear intrusive granitic body that extends northeastward for 12 miles or more. These granitic rocks are younger than the effusive rocks just mentioned and are therefore considered to be not older than the younger part of the Eocene. The mineral deposits in the bedrock from which the placers

.6 Mertie, J. B., Jr., op. cit. (Bull, 864-C), p. 198. 
derived their valuable metals are apparently closely connected with the areas in and adjacent to the granitic intrusive rocks and seem to be distinctly localized. Nineteen records of the fineness of gold from this. area, 15 of which were from Moore Creek and 4 from a small tributary ravine, Nevada Gulch, showed a range of 746 to 769 and an average of 759. The gold, which is described as being rough and showing little wear, is associated with considerable vein quartz. The extremely low fineness of the gold is in striking contrast with the high fineness of the gold from the McGrath area and the moderately high fineness of the gold from the placers of the Iditarod district and of the Ophir area of the Innoko district, all four of which appear superficially at least. reasonably comparable in their geologic setting.

\section{GEORGETOWN DIS'TRICT}

On the banks of the Kuskokwim about 50 miles in an air line south and a little east of the settlement of Flat, in the Iditarod district, is the small settlement of Georgetown, which one time was the general supply center for the neighboring district. Later the prosperity of the camps in the Iditarod district led to the decline of Georgetown and the supplying of much of the area from Flat. In fact, some of the camps in the Georgetown district are really nearer to Flat than they are to Georgetown. In spite of this condition the retention of the distinction between the Georgetown and Iditarod districts serves the useful purpose of separating the placer areas that are situated on streams tributary to the Kuskokwim from those that belong to" the Yukon Basin.

Three small placer areas have been recognized in the Georgetown. district. One includes parts of the valley of Julian Creek, which is a tributary to George River some distance to the northeast of Georgetown and is here referred to as the area northeast of Georgetown. Another of these placer areas embraces the country adjacent to Donlin Creek that is a tribuitary of Crooked Creek and is situated some 25 miles northwest of Georgetown and is referred to here as: the area northwest of Georgetown. The third, called the Kolmakof area, lies not far from the Kuskokwim, east of the old settlement of Kolmakof, and is about 50 miles in an air line southwest of Georgetown. Unfortunately much of the Georgetown district has not been surveyed with the degree of thoroughness that is required even for: exploratory standards so that the available information concerning its geology is extremely sketchy. On the whole, the dominant bedr'ock is probably sandstone and shale of the Upper Cretaceous series, which, in the vicinity of most of the productive placers, have been. intruded by granitic igneous rocks of Tertiary age. The geology of a part of the Georgetown district is shown on the maps accom- 
panying the early report by Mertie ${ }^{5 i}$ on the Ruby-Kuskokwim region, and there is brief mention of the district in his later report.

\section{AREA NORTHEAST OF GEORGETOWN}

As noted above, in the area northeast of Georgetown the only placer deposits that have been mined lately are on Julian Creek, but details as to their geologic setting are lacking. The only record of the fineness of the gold from this area now available to the Geological Survey shows a fineness of 835 . Obviously a single record is inadequate to serve as a basis from which to draw any extensive deductions. It may be of significance, however, to point out that this fineness is practically identical with that shown by the records from Malamute Gulch, in the Iditarod district, and do not differ greatly from some of the records of gold from Otter Creek, in the same district, as set forth on page 206. The close similarity of the fineness of the gold from these three creeks is at least suggestive that there may be much in common in the geologic features of these different areas, especially as the most remote one is not more than 25 miles distant in an air line from the others.

\section{AREA NORTHWEST OF GEORGETOWN}

For a number of years prosperous placer mining has been carried on in the valley of Donlin Creek and some of its small tributaries. Most of this work has been done on claims about 20 miles northwest of Georgetown and about 25 miles south of Flat. The general bedrock throughout this area consists of sandstones and shales of Upper Cretaceous age which here and there have been intruded by acidic igneous rocks of Tertiary age. At least one such mass of intrusive rock is known in the valley of Donlin Creek near its tributary Snow Gulch. Notes on this area are given in a report by Maddren ${ }^{58}$ that was issued 25 years ago.

The gold in the placers, according to Maddren, was originally introduced into the rocks in association with the igneous intrusions. Most of the placers in the area occur as benches on the valley slopes.

Four records of the fineness of the gold from the placers in the Donlin Creek Valley are now available in the Geological Survey. They show gold of considerably higher quality than that from other parts of the district or from the placers of the nearby Iditarod district. All the available records show gold more than 905 fine, with an average of about 912 . Possibly the placer gold, like much

\footnotetext{
${ }^{57}$ Mertie, J. B., Jr., and Harrington, G. L., op. cit. (Bull. 754), pl. 4. Mertie, J. B., Jr., op. cit. (Bull. 864-C), p. 224.

${ }^{58}$ Maddren, A. G., Gold placers of the lower Kuskokwim, Alaska: U. S. Geol. Survey Bull. 622, pp. 251-353, 1915.
} 
of that from the McGrath and Nixon Fork areas, of the McKinley district, may have been derived from veins and mineralized rock that had a much higher fineness than is usual in lode deposits. Demonstration of the full reason for the high fineness recorded must, however, await more intensive studies.

\section{KOLMAKOF AREA}

The only placers in the Kolmakof area of which the Geological Survey has record occur in the valley of a small stream known as New York Creek, which joins Kuskokwim River from the north about 12 miles east (upstream) from the old settlement of Kolmakof. Notes on this area are based on a report by $\mathrm{A}$. G. Maddren, ${ }^{59}$ who made surveys of parts of this area in 1914 . The bedrock in the vicinity of the placers is massively bedded sandstone of the Cretaceous system, much fractured and jointed, associated with highly compressed and crushed shales. These rocks have been intruded by siliceous dikes that occur as small irregular bodies. The bedrock source of the gold that is found in the placers is clearly related to these dikes or to the contact mineralization along their borders. The gold from these placers is rather coarse and nuggety and has evidently not undergone much transportation. The records of the fineness of the gold from this area show a range of 825 to 840 and an average of 830 . This average fineness is closely comparable with the fineness of the gold recorded from Julian Creek in the area northeast of Georgetown.

\section{TULUKSAK-ANIAK DISTRICT}

South of the lowland adjacent to Kuskokwim River and trending more or less southward and extending for a distance of at least 100 miles is a highland area in which at intervals placer deposits occur. Many of the streams flowing from the eastern flanks of this highland are tributaries of Aniak River, which enters the Kuskokwim some 25 miles west (downstream) from Kolmakof. The western flanks of this highland are in general drained by the Tuluksak, Kiselalik, and Kwethluk, or their tributaries, which join the Kuskokwim in the vicinity of Akiak or within a radius of about 10 miles of that settlement. ${ }^{60}$ Parts of this vast area were examined by Maddren in 1914, and the following statements are based principally on his report, as no other Survey party has visited these placers in the intervening years. Throughout much of the country in question the bedrock is sandstone and shale that is regarded as closely equivalent to the Upper Cretaceous beds that are so widespread in the parts of the Kuskokwim Valley already described, and that also occur in the nearby parts of the Iditarod and Innoko dis-

\footnotetext{
50 Maddren, A. G., op. cit. (Bull. 622), pp. 353-355.

${ }^{\infty}$ Maddren, A. G., op. cit. (Bull. 622), pp. 292-360.
} 
tricts, in the Yukon region. To the west of these rocks is an older group. of schists, limestones, and slates that are regarded as of Paleozoic age. Both of these assemblages of sedimentary rocks have been intruded by acidic rocks of granitic or monzonitic composition. The mineralization that has supplied the valuable minerals to the placers seems to have been associated with the intrusion of these igneous rocks. The higher parts of this mountainous area supported local glaciers in the Pleistocene epoch, and the deposits left by them are so fresh that it seems: evident that only recently the glaciers that formed them disappeared.

For convenience this large district has been subdivided into three subordinate areas, the Aniak, Tuluksak, and Kwethluk. Of these the Tuluksak area has been by far the most productive of placer gold and the Kwethluk the least productive.

\section{TULUKSAK AREA}

Tuluksak River, a westward-flowing tributary of the Kuskokwim, is formed by the junction of several headwater streams some 15 miles. from Mount Hamilton. Of these streams, Bear Creek is the best known, and for a number of years the placer deposits of its valley have been actively mined by dredging. Both the Paleozoic and Cretaceous sedimentary rocks form the bedrock in various parts of its valley, and large. and small intrusive masses of acidic igneous rock crop out at many points in its valley. In the vicinity of many of the placers the bedrock is shattered granite. The placer deposits in the valley of Bear Creek are of various types and evidently have been formed under diverse conditions. Some of them have undergone successive modifications so that the gold they contain may have undergone concentration during several different. stages. There seems to be little room to doubt that in general the gold is of local origin and that it was introduced into the veins and country rock - by processes attendant on the intrusion of the igneous rocks that form. such conspicuous features in the area. Most of the ground on Bear Creek that has been mined by dredging is not permanently frozen.

Only two records of the fineness of gold from Bear Creek are now available to the Geological Survey, but as they represent determinations made on several thousand ounces of bullion they are considered to be thoroughly representative. These records indicate that the gold has a fineness of approximately 927 . This high fineness is suggestive of comparison with the high fineness of the gold from Donlin Creek, in the area northwest of Georgetown, and some of the other areas where the gold seems to have been introduced into the country rock by Tertiary igneous rocks and may have been deposited in an especially pure state. So far as available information goes, there is no evidence that the gold has undergone much transportation from its bedrock source to its later burial and incorporation in the placer deposits. 


\section{KWETHLUK AREA}

The only placer mining in the valley of Kwethluk River of which the Geological Survey has record is on Canyon Creek, which is a small tributary of Kwethluk River about 100 miles east of Bethel by trail. The general bedrock consists of sandstone and shale of Upper Cretaceous age. Near the placer claims these sedimentary rocks are cut by a quartz porphyry dike that is supposed to have been the source of the minerals later concentrated in the placers. The placer gold is said by Maddren ${ }^{61}$ to be in small and flat but plump and heavy nuggets of the type called pumpkinseed gold by the miners. Two reports as to the fineness of this gold are practically identical and show that the gold averages approximately 880. Although this indicates a gold of high purity it by no means compares with the record of the average of the gold from Bear Creek in the Tuluksak area as stated above, nor in the gold from many other areas that offhand seem to have analogous geologic setting.

\section{ANIAK AREA}

Centering around Marvel Dome to the southeast of Bear Creek are several small placer areas, some of which have been highly productive. These areas are in the valleys of streams that flow in general eastward and ultimately join Salmon Creek, which in turn is a tributary of Aniak River. The bedrock of all these valleys east of Marvel Dome is dominantly composed of sandstone and shales of the Upper Cretaceous. These rocks have been intruded by numerous masses and dikes of granitic composition which, like those in the other areas in the Tuluksak-Aniak district, presumably have introduced the mineralization that ultimately supplied the valuable minerals to the placers. Some of the creeks that head in Marvel Dome show evidences of having been occupied in their headward portions in the recent past by glaciers. Marvel Creek, however, the only one of the streams in this area for which records of the fineness of its placer gold are now available to the Geological Survey, was not occupied by an ancient glacier. Four records of the fineness of gold from the placers on Marvel Creek, although reporting varied amounts of gold produced during each of 3 different years, are practically identical in showing an average fineness of 880 . This average is the same as was reported for the gold from placers in the Kwethluk area to the west-a condition that is in entire accord with the apparent similarity of geologic setting of the two areas.

o1 Maddren, A. G., op. cit. (Bull. 622), p. 357. 


\section{GOODNEWS DISTRICT}

In the extreme southwestern part of the Kuskokwim region there has been in the past a small production of placer gold from deposits in the vicinity of Goodnews Bay, and the district has, in consequence, been generally known by that name. Lately this district has become. widely known through the large amount of platinum metals that each year is taken from its placer deposits. For the purpose of the present report, however, only the deposits valuable principally for their gold content will be discussed. The general geology of the Goodnews district has been examined by Harrington, ${ }^{62}$ who was attached to a Geological Survey expedition that worked in the district in 1919. A more recent examination of the southern part of the area was made by Mertie $^{62 a}$ in 1937. The examinations, however, did not cover the areas in which the gold placers are best developed.

The bedrock formations in different parts of the district show a wide range in composition, structure, and other physical characteristics. As a whole the rocks have a dominant northeasterly trend, but they have been folded and faulted so that locally they show wide variation from that course. The oldest members of the sequence so far recognized are greenstones, altered acidic and basic igneous rocks, and some small areas of metamorphosed sedimentary rocks-all of which are regarded as pre-Carboniferous. These are succeeded by heavy limestone beds that are associated with led and black shales-all of which are regarded as Carboniferous. Still younger than any of the preceding are sandstones, shales, argillites, cherts, and graywacke, which are undoubtedly mainly Mesozoic and probably largely of Cretaceous. age. The youngest of the recognized Mesozoic rocks are basaltic. intrusives, flows, and tuffs. All of the foregoing members have in: places been intruded by granitic igneous rocks. These intrusions. probably took place in the Tertiary.

The productive gold placers are more or less localized around two. centers that are separated from each other by 15 to 20 miles and that are in the valleys of two different river systems, namely that of Goodnews River, which flows into Goodnews Bay, and the other in the valley of Arolic River, which enters Kuskokwim Bay some 40 miles or more north of Goodnews Bay. The principal placer streams. in the Goodnews River area are Wattamuse, Olympia, Bear, and Slate Creeks, which are about 20 miles or so northeast of the old village of Mumtrak, at the mouth of Goodnews River. In the Arolic area the principal producing placer creeks are Butte and Kowkow

\footnotetext{
n2 Harrington, G. L., Mineral resources of the Gocdnews Bay region, Alaska : U. S. Geol. Survey Rull. 714, pp. 207-228, 1921.

n2: Mertie, J. B., Jr., Platinum deposits of the Goodnews Bay district, Alaska: U. S. Geol. Survey Bull. 910-B, pp. 115-145, 1939; The Goodnews platintm deposits, Alaska:: U. S. Geol. Survey Bull. 918 (in press).
} 
Creeks and Arolic River itself, all of which are some 25 to 30 miles north of Mumtrak.

\section{GOODNEWS RIVER AREA}

All of the known gold placer deposits in the valleys of streams tributary to Goodnews River are in areas where the Mesozoic sedimentary rocks are intruded by the Tertiary granitic rocks. It seems certain that the introduction of mineralization was brought about through the processes attendant on the intrusion and consolidation of these igneous rocks. There are indications that the main valley of Goodnews River was at one time occupied by a glacier that reached to the coast. This large glacier undoubtedly modified and affected some of the tributary valleys as well. Many of the preglacial deposits in the valleys of the streams thus glaciated were destroyed by these advances, and the placers that may have existed dispersed. Many of the placers that are now being mined either escaped such erosion or have been formed subsequently by the reconcentration of the gold in the disseminated deposits or by the recent disintegration, sorting, and transportation of material released from its bedrock source.

Only a single record is available to the Geological Survey at this time as to the fineness of gold from each of Wattamuse, Olympia, and Bear Creeks, and these show fineness of 854,867 , and $8931 / 4$, respectively. Both Wattamuse and Olympia Creeks derive the unconsolidated material of their placers from areas near the granitic igneous rocks. The valley of Bear. Creek, however, differs markedly from these other two in that no granitic rocks have been mapped in the area from which presumably its placers derived most of their material. This suggests the possibility that the gold in those deposits may have undergone transportation from a more distant point of origin, in the course of which journey it underwent a natural refining process by which the more easily removed constituents were extracted and the more resistant gold acquired a higher fineness. Except through the adoption of some such explanation, it seems difficult to account for the higher fineness of gold on Bear Creek as contrasted with the lower fineness of gold from Wattamuse and Olympia Creeks. Much more extensive records from all of these creeks should be obtained before an attempt to draw any far-reaching conclusions as to the true conditions that prevail in the area is justified.

\section{AROLIC AREA}

The geology in the vicinity of the placers of the Arolic area is quite complex and has not been worked out in enough detail to solve the more obscure relationships. A broad strip of the country trending north- 
eastward across part of the valleys of Butte and Kowkow Creeks and the adjacent parts of the Arolic Valley is occupied by Carboniferous limestones. To the north of this tract the bedrock is dominantly of old pre-Carboniferous greenstones, whereas to the south are basaltic flows and intrusives of Mesozoic age. Still farther south in the extreme headwater parts of the valley of Kowkow Creek are Cretaceous sandstones and shales. At the head of Kowkow Creek, cutting the Cretaceous rocks, is a small area of granitic intrusives that are of Tertiary age. In the shattered sediments in the vicinity of this intrusive mass much of the quartz veining probably originated through the processes attendant on the injection of the igneous rocks. Harrington reports that, although he was unable to detect gold in any of these veins he examined, it is probable that some of the related veins may have been the source of the mineralization that was responsible for the formation of the placers in this general area. The geologic processes that have affected these placers in the recent geologic past have not been determined. Harrington states that his investigations did not prove conclusively whether or not the placers on Butte and Kowkow Creeks were closely related to glacial action though the so-called "gumbo" bedrock on Kowkow Creek resembled reworked glacial till. His tentative conclusions were that the placer deposits in the Arolic area were due to stream concentration from bedrock and from the probably auriferous gravels that had previously been accumulated.

Only three definite records of the fineness of gold from the Arolic area are now available in the Geological Survey. These show a maximum range of 871 to $8791 / 2$ and an average of 876 . These records were made of gold from placers in the valleys of Arolic River and Butte and Kowkow Creeks and were respectively 877, 871, and 8791/2. The small range and the moderately high fineness of all of these suggests that the gold has undergone a moderate amount of transportation and is from a fairly common source. The apparently restricted distribution of the known placer deposits in this area indicates a rather strongly localized distribution of the mineralization that contributed to their formation.

\section{SEWARD PENINSULA REGION}

More or less separated from the rest of Alaska is the westward jutting land mass of Seward Peninsula that forms the westernmost outpost of the North American Continent. Embracing an area of about 20,000 square miles, this region was among the earliest of the Alaska regions in which placer mining was carried on successfully, and in the nearly 40 years since the first significant output from its camps it has yielded gold to the value of more than $\$ 100,000,000$, even at the old price of gold. Although to many persons, the whole 
placer area of this peninsula is often improperly associated with the name Nome, it should be recognized that while the placers of the Nome district have produced about two-thirds of the gold that has been recovered from the deposits of the peninsula, there are productive placer mines widely scattered throughout the peninsula so that there is hardly a tract 25 miles in diameter that has not contributed some placer gold to the foregoing total. The different parts of the peninsula show such marked differences in their geologic features that it is desirable to describe small parts rather than to cover the area as a whole. Eight subdivisions have been made which are called districts and these have been further subdivided into areas. The districts in the southern part of the peninsula, commencing with the easternmost, are named Koyuk, Council, Bluff, Solomon, and Nome. The districts in the more northern part of the peninsula, again named from east to west, are Fairhaven, Kougarok, and Port Clarence. In the following descriptions an alphabetical arrangement of the different districts has been adopted.

The most comprehensive report on the geology of much of the southern and western parts of Seward Peninsula is that by Collier, Hess, Smith, and Brooks; ${ }^{63}$ for southeastern Seward Peninsula, that by Smith and Eakin; ${ }^{04}$ and for northeastern Seward Peninsula, that by Moffit..$^{05}$. In addition to these more general reports, a number of others dealing with more restricted areas have been published by the Geological Survey, and so far as they bear on the subjects treated will be referred to in the appropriate places in the following pages.

As shown by the summary table on pages $160-161,287$ records of the fineness of gold from the different parts of Seward Peninsula have been available for use in the present study. Of these, 168, or approximately 59 percent, are of gold with a fineness between 850 and 900 ; 88 , or approximately 31 percent, are of gold higher than 900 fine; 30 , or 10 percent, are from 800 to 850 fine; and only 1 , or considerably less than 1 percent, is below 800 fine. On the whole, therefore, the fineness of the gold from the placers of Seward Peninsula seems to average higher than that of any other regions except the Kuskokwim and the Cook Inlet-Susitna regions.

\section{BLUFF DISTRICT}

Bluff is a small settlement on the southern coast of Seward Peninsula about 50 miles in an air line east of Nome. Near this town was

\footnotetext{
a Collier, A. J., Hess, F. L., Smith, P. S.. and Brooks, A. H., The gold placers of parts of Seward Peninsula, Alaska: U. S. Geol. Survey Bull. 328, 343 pp., 1908.

64 Smith, F'. S., and-Eakin, H. M., A geologic rcconnaissance in southeastern Seward Peninsula ditid the Norton Bay-Nulato region, Al:askal U. S. Geol. Survey Bull. 449, 146 pp., 1911.

as Moffit, F. H., The Fairbaven gold placers, Seward Peninsula, Alaska: U. S. Geol. Survey Bull. 247,85 pp., 1905.
} $252006-41 \longrightarrow 7$ 
one of the richest tracts of placer ground that has been found in the entire peninsula, and even now it supports considerable mining activity. The general bedrock in the vicinity of the placers is rather massive limestone of Paleozoic age, but in the areas more remote from the placers there are highly metamorphic schists which possibly are prePaleozoic or early Paleozoic. Cutting these old schists in places are greenstones and.. related igneous rocks that have themselves been strongly metamorphosed. No other igneous rocks are known to occur in the entire district though, within a radius of 25 miles or so to the east, north, and west granitic rocks are known to crop out. Abundant evidence of mineralization in the bedrock at many places in the Bluff district has been noted. Cathcart ${ }^{66}$ has summarized the records regarding the veins in this district and has shown that though the tenor of gold in any individual vein may be low the great number of veins that are known to occur close together might make it feasible to mine the entire body in which they are most numerous. It is believed that this intensively mineralized bedrock was the source from . which the placers derived their valuable gold content. Undoubtedly the material eroded from these veins underwent handling by various geologic processes before finally coming to rest in the present placers. Dominant of those processes was undoubtedly stream erosion and concentration, but marine agencies also played a part. There is, however, no evidence that any part of the Bluff region was ever glaciated or directly affected by glacial ice.

Unfortunately, no detailed records regarding the fineness of the gold produced from the beach placers of this district in the early days are now available. Brooks, ${ }^{67}$ however, in a report based on surveys made there in 1900, states that the beach gold from the vicinity of Bluff was much coarser than that from the beaches near Nome, averaging about 12 pieces to the cent, and it had a fineness of 870 . Eight records of the fineness of the gold from Swede Gulch, a small ravine a few miles east of Bluff, show an extreme range of 865 to 886 and an average of 869 . This average is in astonishing agreement with the fineness reported by Brooks for the beach gold of this district.

\section{COUNCIL DISTRICT}

Directly north of Bluff and about 25 miles distant is the settlement of Council, which for a long time was the center for a number of prosperous mining camps in the vicinity. Lately mining activity has

Catheart. S. H., Metalliferous lodes in southern Seward Peninsula, Aluska: U. S. Geol. Survey Bull. 722, pp. 186-197, 1922.

67 Brooks, A. H., Richardson, G. B., and Collier, A. J., Reconinaištances in vthe Cape Nome and Norton Bay reglons, Alaska, in 1300 : U. S. Geol. Survey, Special Pub., pp. 104$105,1901$. 
decreased, but in 1937 there were four dredges in operation there and a number of small outfits at work on streams within a radius of 10 to 15 miles of the town. The placers on which most work has been done are in the lowlands of Niukluk River, immediately adjacent to Council, and in the valleys of Melsing and Ophir Creeks, which head in the hills to the north of that town. A more isolated placer area is in the valley of a tributary of Fish River some 15 miles enst of Council. For convenience these two areas will be referred to here as the Niukluk area and the Fish River area.

\section{NIUKLUK AREA}

The bedrock throughout most of that part of the Niukluk area in which productive placers have been found consists either of highly metamorphic schists and thin limestones or of massive, heavily bedded, and partly recrystallized limestone. The age of these sedimentary formations is still much in doubt, some correlations placing the schists as far down in the geologic column as the pre-Cambrian and others suggesting even as late an age for the limestone as the Carboniferous. In the absence of more evidence it seems unsafe to go further at this time than to accept a probable. Paleozoic age for the limestone and at least as old an age for the major parts of the schists, with the realization that they may even be of pre-Cambrian age. Some greenstones intrude both the schists and the limestones and have experienced a strong amount of deformation so that many of their original features have been destroyed or extensively altered. After the deposits mentioned above were laid down there was considerable igneous activity during which granites were intruded. These doubtless were accompanied by some mineralization of the rocks adjacent to their contacts. None of these granitic intrusions are known to have taken place in the immediate neighborhood of the productive placers, but several such masses have been found in the Bendeleben Mountains, some 20 miles or more north of Council, in which Ophir Creek and some of its tributaries head. Glaciers at one time occupied some of the ligher parts of the mountain area and flowed down the preexisting valleys for some miles. So far as known, however, none of these nowvanished glaciers extended as far downstream as the site of any of the present placers.

On the whole, the available records of gold from the Niukluk area seem to show an average fineness of about 875 , but there is considerable range in the fineness of the gold from the valleys of different streams. In the following table the records are given for certain of the placers in the valleys of the streams named. 
Fineness of placer gold from Niukluk area, Council district of Seuard Peninsula region

\begin{tabular}{|c|c|c|c|}
\hline Creek & $\begin{array}{l}\text { Number } \\
\text { of records }\end{array}$ & $\begin{array}{l}\text { Range of } \\
\text { fneness }\end{array}$ & $\begin{array}{l}\text { Average } \\
\text { fineness }\end{array}$ \\
\hline $\begin{array}{l}\text { Niukluk River... } \\
\text { Melsing } \\
\text { Basin } \\
\text { Ophir. } \\
\text { Crooked } \\
\text { Albion Gulch }\end{array}$ & $\begin{array}{r}1 \\
5 \\
1 \\
17 \\
27 \\
6\end{array}$ & $\begin{array}{r}8791 / 2 \\
886-895 \\
914 \\
1846-924 \\
2784-905 \\
8261 / 2-845\end{array}$ & $\begin{array}{r}879 \\
891 \\
914 \\
1885 \\
2864 \\
838\end{array}$ \\
\hline Total & 37 & & 875 \\
\hline
\end{tabular}

1 Three records above 900 .

2 One record only above 888 ; one record only below 862 .

The record of the gold from Basin Creek seems rather out of line with records from other creeks because it is so high. Basin Creek is a small tributary of Melsing Creek so that its gold would be expected to have undergone less natural refinement than that of the parent stream. As noted, three of the records of the gold from Ophir Creek are above 900 and one is 924 , which is the highest record of any gold from this area. Albion Gulch is a small ravine tributary to Ophir Creek and with the exception of one record from Crooked Creek shows the lowest fineness of gold of any of the creeks in the area.

\section{FISH RIVER AREA}

The only placer deposit in the Fish River area east of Council is in the valley of Aggie Creek. Only two records are available to the Geological Survey at this time as to the fineness of the gold from these placers. These records show the unusually large spread of 902 to $9601 / 2$. Some doubt is felt, therefore, as to the general applicability of the precise numerical value stated, but there can be no doubt that in this area there is gold of high fineness. The geology in the vicinity of Aggie Creek appears superficially to have much in common with parts of the better known Niukluk area in that the dominant bedrock is limestone and schists that are assumed to be Paleozoic or older. A small mass of granite crops out in the highland on the opposite side of the ridge from that in which Aggie Creek heads, but so far as known no granite in place is found in the basin of Aggie Creek. No effects of past glaciation are recognized in the area.

\section{FAIRHAVEN DISTRICT}

The Fairhaven district, as that term is used in this report, embraces all that part of northeastern Seward Peninsula that lies north of the Koyuk district on the south and the Kougarok district on the west. It may be roughly subdivided into four areas in which placer mining has been active. Of these, the greatest production has been from the area adjacent to the settlement of Candle, near the mouth 
of Kiwalik River. The second largest production of placer gold from this district has come from deposits in the valleys of Inmachuk River and its tributaries, which are some 30 miles or more west of Candle. Two small areas are tributary to Buckland River and to the head of Kiwalik River. Placer mining in the Buckland area centers around Bear Creek and its tributaries, which are some 30 miles southeast of Candle and flow eastward to join Buckland River. The area at the head of Kiwalik River embraces the valleys of the main stream and its tributaries, especially Glacier and Quartz Creeks, which are 20 to 25 miles south of Candle. This area in its southern part abuts on the Koyuk district.

The best general description of the district is contained in a report by Moffit, ${ }^{68}$ which was written nearly 35 years ago and has not been revised subsequently. In the main, the bedrock in most of the placer areas consists of highly metamorphic schists that may be as old as the pre-Cambrian, with which are associated later limestones and other sedimentary rocks of supposed Paleozoic age. Some greenstones cut these beds and have themselves been involved in some of the mountain-building episodes that have affected the district. In the Mesozoic there were extensive effusions and intrusions of basic igneous rocks that, in the main, have an andesitic composition. At places, cutting all these rocks, were subsequent intrusions of granite, most of which are now exposed at the surface in moderately small tracts, some of which are 5 miles or so in diameter. Still later, in the Tertiary and extending into the Quaternary, extensive flows of basaltic lava were poured out over the country filling in many of the preexisting lowlands and even mantling the hillsides of the surrounding highlands. No glaciation is known to have affected any part of the district directly.

\section{CANDLE AREA}

The bedrock in the vicinity of the principal placer deposits in the Candle area is dominantly the schists and limestones of the Paleozoic or older groups. In nearby areas, however, members of the assemblage of Mesozoic lavas mantle much of the lowland areas to the east and form the greater part of the highland that separates the valley of Kiwalik River from that of Buckland River to the east. The principal producing creek in the area is Candle Creek, but a number of the valleys of its tributaries, such as those of Jump and Patterson Creeks, have also yielded considerable gold. The only mass of intrusive granite in the valley of Candle Creek lies some 12 miles southwest of the town of Candle and crops out in a small tract on the ridge between Potato and Ptarmigan Creeks.

${ }^{68}$ Moftt, F. H., op. cit. (Bull. 247), 85 pp., 1905. 
Moffit states that the gold of the Candle area, as well as neighboring parts of the district, is unquestionably largely of local origin and has been concentrated from an original supply widely disseminated in small quartz veins and stringers and impregnated zones in the bedrock. Most of the gold is said to be rough and unworn, and the occurrence of many nuggets with quartz still adhering to them indicates that the gold has not traveled far from its point of origin. Placer deposits due to beach concentration, as well as high benches and deposits formed in the lowlands of the present stream valleys, have been recognized in the Candle area, and doubtless the gold in each type would show distinctive characteristics if examined critically.

The only placer deposits in this area for which records of the fineness of their gold are available to the Geological Survey occur on Candle and Patterson Creeks. Twenty-eight records of gold from Candle Creek show a range of $8193 / 4$ to 875 and an average fineness of 850. Six records of the fineness of gold from Patterson Creek show a range of 809 to 842 and an average of 821 . The difference in the average gold from these two streams would seem to accord well with the expectation that the gold on Candle Creek had undergone more thorough refinement through transportation and natural processes than that from a smaller stream nearer the head of the valley. This does not, however, tell the whole story, and considerably more detailed evidence must be collected and analyzed before an adequate under= standing can be obtained of the causes of varying fineness within even single claim-lengths on either Candle or Patterson Creeks.

INMACHUK AREA

The bedrock in the vicinity of placer deposits in the Inmachuk area resembles in many features that in the vicinity of Candle, but extensive areas of metamorphic limestone form much more of the surface exposures. In addition, in a number of valleys the sedimentary bedrock has been covered by extensive lava flows of late Tertiary or Recent agé, which in places have been trenched through by the present streams and now appear as palisades along the valley walls. Such a condition prevails along the northwestern bank of the Inmachuk Valley for miles above and below the mouth of its tributary, Pinnell River, and in places along the slopes of the valley of Hannum Creek.

The gold from the Inmachul River Valley is described by Moffit as heavy and black on the surface. Apparently it is little worn; and nuggets having a value of several dollars each are by no means uncommon. A large amount of "iron stone". and some pyrite is associated with the valuable metallic constituents: in the clean-ups. The six records of the fineness of gold from this area now available to the Geological Survey show finenesses ranging from 852 to $8981 / 2$. Three of these records pertain to gold from placers on Inmachuk River and 
range from 891 to $8981 / 2$; two of them are of gold from Cunningham Gulch and are 852 and 880 and one from Discovery Gulch shows gold 895 fine.

\section{BUCKLAND AREA}

The bedrock in the Buckland placer area, unlike that in most of the other placer areas of the Fairhaven district, is composed of eruptive and effusive rocks of andesitic and granitic composition and of Mesozoic or younger age. So far as known, no schists or limestones have been reported in that area. As has been noted, the principal placer production from this area has come from placers in the valley of Bear Creek and its tributaries Sheridan and Cub Creeks. Moffit describes the gold from this area as bright golden yellow; that from Bear Creek itself and from Cub Creek as flaky, and that from Sheridan Creek as chunky and heavy. Considerable pyrite and black sand are caught in the sluicing operations with the gold. There seems to be every reason to believe that the gold has been derived from local sources and has not been transported far from those sources. Seven records of the fineness of gold from placers on Bear Creek are available. They show a range of $8671 / 2$ to 904 and an average of 895 . One of these records shows gold $8671 / 2$ fine, but none of the others are below $8951 / 2$, so that some doubt is felt as to the accuracy of the extremely low record. If this low record were excluded the average for the district would become 899 .

The Geological Survey has also received one record of gold from a stream called Koopuk Creek, which is said to be a tributary of Buckland River. The exact location of this stream is not known, and its output of placer gold has been insignificant. The occurrence, however, is especially interesting because the available record reports that "the fineness of the gold is 956, which places it among the purest gold reported from the entire Seward Peninsula region.

\section{KIWAIIK AREA}

The bedrock of the southern part of the Kiwalik River Valley, here called the Kiwalik area, partakes of characteristics in part comparable to those of the Candle area and in part to those of the Buckland area. This is probably because in most of the area to the west of the main river the bedrock is formed of members of the great group of early Paleozoic or older schists and limestones, whereas to the east of the stream the country rock is formed of the Mesozoic volcanics and Mesozoic and later granites, together with extensive flows of lavas, some of which are as recent as the Quaternary. This area has not yet contributed notably to the gold output of the Seward Peninsula region, and most of the deposits that have been developed have been mined by small outfits. 
Six records of the fineness of gold from Quartz Creek, which joins Kiwalik River from the east, range from 858 to $8641 / 2$ and average 860 . The one record available from streams entering Kiwalik River from the west in this area is from Glacier Creek, and it shows a fineness of $8471 / 4$. From these records it appears that the difference in the fineness of gold from the valleys of these two streams that seem to have such different geologic environments is really very slight. The gold from this area, therefore, seems to have a fineness more closely comparable with that of the Candle area than that of the Buckland area.

\section{KOUGAROK DISTRICT}

The Kougarok district occupies most of the central part of Seward Peninsula. Its placers occur principally in the valleys of Kougarok River and the tributaries that join it in the northern part of its valley and in an area adjacent to Coffee Dome, which is drained in large part by streams tributary to Kougarok River but is in the southern part of that drainage basin and is more or less distinct from the northern part of the valley. The northern section has been called the Taylor area and the southern the Coffee Dome area. Some 25 miles south of the Coffee Dome area and usually not considered a part of the Kougarok district is a small placer area generally referred to as the Iron Creek area. For convenience in this report this rather isolated area, which lies more or less equidistant from the Kougarok, Nome, and Solomon districts and partakes in a measure of the features of all three, is discussed as though forming part of the Kougarok district.

The general geology of the Kougarok district has been described in some detail by Brooks ${ }^{69}$ and the distribution of the principal formations has been represented on the maps accompanying that report. The bedrock throughout much of the central and northern part of the productive placer area of the Kougarok district consists of the old highly metamorphic mica schists and related rocks. In the western part of the district are extensive areas of limestones of Silurian and Ordovician age that are somewhat metamorphosed and deformed but on the whole much less so than the schists. In the eastern part of the district there is also an extensive but somewhat smaller. area of limestone. The age of this limestone has been variously set from Silurian to Carboniferous, and possibly it has that continuous range. On more critical study, however, it may be found to be divisible into various smaller units belonging to different series and systems. Igneous rocks on the whole are rare throughout most of the Kougarok district, though a short distance north of the head of the Kougarok

${ }^{\infty}$ Collier, A. J., Hess, F, L., Smith, P. S., and Brooks, A. H., The gold placers of parts of Seward Peninsula, Alaska, including the Nome, Council Kougarok, Port Clarence, and Goodhope precincts: U. S. Geol. Survey Bull. 328, pp. 294-328, pls. 10, 11, 1908. 
Valley there is an area of granite about 4 miles in diameter, and at many places to the south and east there are extensive flows of the Recent basalts. In the schists and limestones at a number of places are greenstone dikes and small masses that probably were intruded prior to the Mesozoic era. Neither the old greenstones nor the late lavas seem to have had significant effect on the process of mineralization which later contributed valuable metallic minerals to the placers. Although the Kigluaik Mountains to the south and the Bendeleben Mountains to the east of the Kougarok district were centers of glaciation during the recent past, none of their glaciers extended into the district or had a direct effect on any of their geologic features.

\section{TAYLOR AREA}

The part of the Kougarok district here called the Taylor area more or less closely coincides with that referred to by Brooks as the northern placer area. In it productive placers have been found not only in the present stream gravels of the main stream and the bench deposits that form terraces here and there along its valley slopes but also in similar deposits that occur in most of the valleys of the side streams, including those from North Fork northward. The same conditions are found even in some of the valleys of the streams that flow northward into Shishmaref Lagoon from the divide that separates them from the headward tributaries of Kougarok River.

As in many of the other areas in Seward Peninsula, there is general evidence of widespread mineralization in the bedrock. The valuable minerals associated with this mineralization when unlocked by weathering from the veins and stringers in which they were formed and concentrated by the streams and other transporting agencies are what has given value to the placers. The process of concentration was not a simple single incident but was interrupted and renewed a number of times as is shown by the bench deposits at different elevations above the present water levels. The gold in the resulting placers, therefore, may have undergone several periods of reconcentration before coming into its present position. Thus, the gold may have been subjected to considerable wear even though that wear did not involve transportation to a point far from the bedrock source of the gold.

Practically all of the gold from the placers in the Taylor area has high fineness. Twenty-five records of gold from the deposits of the main Kougarok River Valley show a range of 868 to 931 and an average of 904; two records of gold from Harris Creek show 873 and $8871 / 2$; one from Henry Creek is 906; two from Macklin Creek 9071/2 and 910; and one from Dick Creek, which is one of the northward-flowing streams whose valley lies north of that of Kougarok River, was $8981 / 2$. The average of all of these 31 records for the Taylor area is 903 . It is interesting to note that the gold from Macklin Creek, which is at 
the extreme head of the Kougarok Valley, has nearly as high fineness as that from any other part of the valley.

\section{COFFEE DOME AREA}

The Coffee Dome area lies in the extreme southern part of the country tributary to Kougarok River. The bedrock throughout much of the area is the same as that near the productive placers of the Taylor area, but in addition there is a considerable area occupied by a hard brittle black quartzitic graphite slate, in which quartz mineralization is especially abuidant. Placer deposits of two types, namely stream and bench placers, have been found in the area. The pay streaks on many of the claims lie on false bedrock formed of sticky blue clay and are under an overburden that in many places is too thick to permit its being removed profitably and yet not thick enough to make it practicable to utilize ordinary sinking and drifting methods. There seems to be little room to doubt that the gold in these placers has been derived from distinctly local sources and has not been moved far from its original source. A number of good-sized nuggets have been recovered from the placers of this area, and much of the gold is rather chunky and irregular in shape.

Three records of gold from placers on each of Coffee Creek, Wonder Gulch, and Dahl Creek showed fineness of 857,895 , and $8841 / 2$, respectively. This area is part of the tract which Brooks described as the southern belt of mineralization of the Kougarok district, and in addition to the area in the vicinity of Coffee Dome, mentioned above, is prolonged to the northeastward crossing the southern part of the Kougarok Valley and the valleys of Garfield Creek, a tributary of Kuzitrin River, and Turner and Goose Creeks, tributaries of Noxapaga River. Unfortunately the Geological Survey has no records of the fineness of gold from the placers in the valleys of these streams to the northeast of the Coffee Dome area.

\section{IRON CREEK AREA}

The bedrock of the Iron Creek area differs in many respects from that in the Taylor and Coffee Dome areas in that as a whole the limestones are much less extensive and the black brittle quartzites are almost entirely lacking. In the headward part of the valley of Iron Creek and its tributaries such gold as is recovered has a rusty appearance and is rather rough, whereas in the more northern or downstream parts of the valley both rusty and bright gold are common. Nuggets weighing as much as 30 ounces have been recovered from the placers of Iron Creek, and smaller nuggets weighing an ounce or more have been fairly common. Judging from the physical characteristics there seems to be little room to doubt that the placer 
gold has come from distinctly local sources and has not been transported far from its point of origin. Part of the Iron Creek area has been subjected to the effects of glaciation that centered in the nearby Kigluaik Mountains to the north, and some foreign material has been brought into the area by the processes attendant on the advance and waning of those ice masses. There has also been recent revival of downstream cutting, whereby in the northern part of the valley the stream now flows in a narrow trench incised below the old drainage level. This dissection has not yet progressed far enough upstream to have cut into the old gradient in the headward parts of the valley.

Only three records of the fineness of the gold from the Iron Creek area, and all of them from the placers of Iron Creek itself, are available to the Geological Survey. These show a range between 891 and $9141 / 2$ and an average of 905 .

\section{KOYUK DISTRICT}

Lying south of the Fairhaven district and embracing primarily the drainage basin of Koyuk River is the Koyuk district. For convenience its geographic limits have been extended to include in addition some of the adjacent area to the east of Norton Bay, part of which lies some 25 miles southeast of the mouth of Koyuk River. This large district has been subdivided into three areas, called Dime, Sweepstake, and Ungalik areas, names taken from the principal streams that traverse them. Of these three, the Dime area has produced the most gold. As its name implies, its placers are mainly confined to the valley of Dime Creek, which joins Koyuk River from the north, some 6 miles west of the place where the course of the Koyuk changes from nearly due east to nearly south. The Sweepstake area lies north of the Dime Creek area and includes part of the valley of Peace River and its tributary Sweepstake Creek. Peace River flows into Koyuk River some 8 miles in an air line west, or upstream, from the mouth of Dime Creek. The Ungalik area is some 25 miles southeast of the month of Koyuk River and includes some small placer tracts near the southern part of the valley of Ungalik River.

The geology of parts of this area has been examined by a number: of geologists of the Geological Survey, and their findings have been published. Harrington ${ }^{70}$ has summarized not only the earlier reports but also the results of his own studies. The geology of the different parts of the district show widely different characteristics, so that it will be more useful to note the features of each area sepa-

\footnotetext{
${ }^{70}$ Harrington, G. L., The gold and platinum placers of the Kiwalik-Koyuk region, Alaska : U. S. Geol. Survey Bull. 692, pp. 369-400, 1919.
} 
rately rather than to attempt to describe the geology of the district as a whole at this place. It may be pointed out, however, that the junction between the Paleozoic and older sedimentary rocks that form most of Seward Peninsula to the west and the Cretaceous rocks that extend from Seward Peninsula eastward uninterruptedly into the Yukon region follows more or less closely the course of Koyuk River for 15 miles from its mouth upstream. As a consequence, the two parts, lying on opposite sides of this line differ greatly in their surface features and geologic history.

DIME AREA

The bedrock throughout most of the productive placer area of Dime Creek consists of somewhat metamorphic members of the Mesozoic andesitic rocks similar to those already described in the Buckland area and at the head of Kiwalik River in the Fairhaven district. There are, however, in the neighborhood some exposures of the old metamorphic schists and slates and some exposures of the conglomerates of the Upper Cretaceous sediments and of the Tertiary and Quaternary basaltic lavas. Both bench and stream placers cccur in the area, and the placers are mined by ordinary open-cut methods, by dredging, and by shaft and drifting. Associated with the gold in the clean-ups is a small amount of platinum. Mr. Harrington makes no definite statement as to the original source of the gold but evidently regards it as not the same as that of the platinum metals, which he believes probably were derived from a peridotite that crops out at the head of the Dime Creek Valley.

All of the 27 reports that are available as to the fineness of gold from the Dime area show that the gold is of exceptional purity and has a remarkably uniform fineness. The lowest fineness reported in these records is 950 , the highest 966 , and the average 956 . This average is only little below the record of 958 for the average gold of the Koyukuk district of the Yukon region, which stands as the highest average for any of the placer camps throughout Alaska. ${ }^{71}$ No satisfactory explanation of the high quality of this gold has yet been advanced, and one is at present at a loss to understand the great difference in fineness shown between it and the gold from the Bear Creek Valley in the Buckland area, which appears to have originated from comparable sources and to have been unlocked and concentrated through many of the same geologic processes but averages nearly 60 points lower.

\footnotetext{
71 The close similarity between the names Koyuk and Koyukuk might be soniewhat confusing to a person not familiar with Alaska. They, however, refer to entirely differcnt parts of the Territory, and the principal placel aleas in each are separated from those in the other by an air-line distance of more than 300 miles.
} 


\section{SWEEPSTAKE AREA}

The principal placer deposits in the Sweepstake area lie some 8. to 10 miles northwest of those on Dime Creek. Throughout the southern downstream part of the valley of Sweepstake Creek the bedrock is composed dominantly of members of the Mesozoic volcanic rocks, but the headwaters of many of the branches that unite to form the main stream rise in the granitic mass that also forms part of the divide in which Quartz Creek, of the area at the head of Kiwalik River, and Cub Creek, a tributary of Bear Creek in the Buckland area, have their source. The placer deposits on the whole are rather shallow, and the fragments of rock, as well as of the gold, are rather rough and angular as though they had undergone only little movement. Small amounts of platinum metals occur in the placer deposits, but presumably have been derived from some source other than that which furnished most of the gold.

Only two reports are available in the Geological Survey as to the fineness of gold from the placer deposits in the valley of Sweepstake Creek. These show fineness of 835 and 837 , with an average of 836 . This average is somewhat lower than that shown for the gold from Quartz Creek, namely 860, although the geologic conditions in the valleys of these two streams appear to be essentially identical. It is surprising that the average of the gold from Sweepstake Cireek, as shown by these records, is 120 points lower than that from Dime Creek. Possibly the fact of the closeness of granitic rocks in the headwaters of the Sweepstake Valley and the entire absence of this type of rock in the Dime Creek Valley is largely responsible for this great difference, if, as seems likely, the mineralization in the two areas was related to the processes that accompanied and followed the emplacement of these igneous masses later in the Cretaceous or in the Tertiary.

\section{UNGALIK AREA}

Unlike the two areas in the Koyuk district described above, the Ungalik area, lying east of Norton Bay, contains no rocks that are recognized as older than the Upper Cretaceous. Some disseminated particles of gold have been recognized in the unconsolidated deposits at a number of places in this area, but the only deposits that have been mined on a commercial scale are those in the southern part of the valley of Ungalik River and especially in the vicinity of Bonanzil Creek. These deposits were described ${ }^{72}$ as having for their bedrock dark slates and shales of Cretaceous age. A short distance north of Bonanza Creek are conglomerates that are believed to mark the basal member of the Cretaceous sequence in this region. About 6 or 7

\footnotetext{
${ }^{79}$ Smith, P. S., and Eakin, E. M., op. cit. (Bull, 449), pp. 105-108, 1911.
} 
miles east of the placer deposits a conspicuous peak, Christmas Mountain, is formed of intrusive diorite and syenite porphyry, which cuts through the Cretaceous sedimentary rocks. This intrusion is believed to be the source of the mineralization that supplied much of the gold that was later collected in the placers of the adjacent areas. By thus attributing the mineralization to this specific intrusion it is not intended to imply that other similar intrusions do not occur at other places in the area that have not yet been explored, or that the effects of that intrusion were restricted to the immediate vicinity of the part of the intrusion that is now exposed. In fact the effects of this mass are to be recognized in the small dikes of granitic composition that cut the bedrock in the vicinity of the placers and introduced sulphides and other metallic minerals into the shales near their contacts.

Only one record of the fineness of the gold from the placers of Bonanza Creek is now available. This shows gold of high purity, with a fineness of 926 . Smith described the gold that was being mined at the time of his examination as medium coarse and of a dark-reddish color. Several nuggets were seen that had fragments of quartz still adhering to them. The largest nugget that had been found up to the time of his visit weighed somewhat more than an ounce. Much black sand was recognized in the concentrates, but garnet or so-called "ruby' sand was practically absent from all parts of the creek.

\section{NOME DISTRICT}

By far the larger part of the gold that has been won from the placers of Seward Peninsula has come from those of the Nome district, by which term is included the area within a radius of 20 miles or so of Nome. Many types of placers occur in this district, including beaches both of present-day and of ancient times, stream placers along present streams or as benches above or below the present water grades, and old stream channels that were formed so long ago that the drainage courses they followed differ greatly in direction from those of the nearby present-day streams. Glaciation also affected the northern part of the district so that tongues of ice at one time surmounted highlands that now form divides between different drainage basins. These and many other facts relating to the Nome district have been learned in the course of the Geological Survey's investigations of the district and have been summarized by Moffit. ${ }^{73}$. According to these investigations, the bedrock throughout the placer areas of the Nome district is predominantly highly metamorphic schists and limestones, which have been called the Nome group and have been assigned to an

\footnotetext{
${ }^{73}$ Moffit, F. H., Geology of the Nome and Grand Central quadrangles, Alaska: U. S. Geol. Survey Bull. 533, 140 pp., 1913.
} 
early Paleozoic or pre-Paleozoic age. Cutting these old sedimentary rocks at a number of places are greenstone dikes and masses that were intruded late in the Paleozoic or possibly in the Mesozoic and have themselves been extensively deformed and altered. Later than any of the preceding rocks, there were intrusions of granitic rocks. None of the granitic rocks occur in close proximity to the richer placer areas, the nearest known locality being at Cape Nome, some 10 miles or more east of Nome, and the most extensive areas being in the Kigluaik Mountains, which are some 25 miles or more north of Nome. Mineralization in the form of innumerable small stringers and in places larger veins is widespread in the rocks of the Nome group. Many of these veins contain visible amounts of metallic minerals, but many are composed entirely of quartz. There are also indications of disseminated minerals in the schists that are not connected with any apparent direct veination. All these types of mineralization doubtless furnished materials that, when loosened from their bedrock source and sorted and concentrated under the varied natural processes of weathering and transportation, have contributed to the formation of the placers.

On almost every stream in the vicinity of Nome, at one time or another, some placer gold has been mined. In order that the available records of the fineness of gold from some of these deposits may be presented in some systematic order the district has been subdivided into five smaller areas, based on their geographic location. These areas have been called by the abbreviated titles Beaches, Snake River, Nome River, Cape Nome, and Oregon. It should be understood that the areas represented by these brief titles include all the tributaries to the streams named and the contiguous area; thus the term Snake River area, for instance, should more properly be amplified to "Snake River and its tributaries and the areas contiguous thereto." Each of these areas will be discussed in more detail in the succeeding pages.

All of the available records of the fineness of the gold from the Nome district shows that the gold is of remarkably uniform quality and of moderately high fineness. Of the 75 records tabulated, only one shows gold less than 840 fine, and none are higher than 90 . This marked uniformity, which suggests the general similarity of conditions of placer accumulation throughout the district is in rather strong contrast to some of the other districts of Seward Peninsula, such, for instance, as Council and Fairhaven.

\section{BEACHES}

The fabulously rich beach placers that led to the early rush to Nome and that were later surpassed by the buried ancient beaches that lie several miles inland are perhaps the most distinctive of the 
placers of the Nome district. The gold-bearing portion of the present beach extended for a dozen miles or more both east and west of Nome, though the richer portion occupied a much more restricted tract. The principal productive portions of the old beaches were between the southern parts of the Nome and Snake River Valleys and in the tract between the present shore line and the rocky hills that lie some 3 or 4 miles inland to the north. Obviously the bulk of the unconsolidated deposits of which these beach placers are composed has been brought into its present position by the work of streams and marine action. The interrelation between these various processes during the time the deposits were being accumulated and in the long time that has elapsed since the ocean withdrew from its former inland strands presents a complex series of events that have not yet been satisfactorily worked out in detail. Even the age of the different old beaches has not been thoroughly settled. Certain fossils from the older of the ancient beaches were identified by Dall ${ }^{74}$ as Pliocene and others from younger of the ancient beaches as Pleistocene to Recent. Some doubt has been raised as to the dependence that can be placed on the paleontologic evidence, which seems to run counter to some of the physiographic evidence, and Brooks ${ }^{74 a}$ regarded all of the coastal plain deposits near Nome as Quaternary.

Twenty records of the fineness of gold from the old beach deposits near Nome have been tabulated for the present investigation. For 11 of these records unfortunately, only the actual amount of fine gold and silver were stated and the amount of dross was not given. To use these records that involved more than 500,000 ounces, therefore, required the adoption of some assumption. While recognizing the fallacy of the procedure, the fineness has been computed as though no dross had originally been present, and as a result these records are perhaps three to six points higher than they would have been had the full information been available (i. e., the sum of silver and gold was taken as 1,000 instead of perhaps 996 or 992 , as seems to be the usual character of the beach gold as shown by the other analyses). The range of all 20 records was from 876 to $9031 / 2$, with an average of 898 . The average of the 11 records mentioned above, computed separately by the method outlined, is 901 , and the average of the other 10 records, also computed separately, is 896 . It is therefore evident that the inexact method used does not introduce a significant error if the average fineness of the gold from these old beaches is assumed to be approximately 898 .

\footnotetext{
${ }^{74}$ Dall, W. H., Pliocene and Pleistocene fossils from the Arctic coast of Alaska and the auriferous beaches of Nome, Norton Sound, Alaska: U. S. Geol. Survey Prof. Paper 125, pp. 23-37, 1920.

74a Brooks, A. H., personal communication.
} 
Although the records of the gold from all the old beaches shows in general marked uniformity, the one record available from the so-called "Second Beach," which next to the present beach is the youngest in the area, indicates a lower fineness (876) than that of the gold from any of the other beaches for which records are available. The difference between the records of gold from this beach and the average from the other beaches, however, is so small that on the basis of a single report it seems unwarranted to place much emphasis on the record as it now stands.

\section{SNAKE RIVER AREA}

Entering Norton Sound at Nome is Snake River, which drains much of the country immediately west of the town and whose headwater tributaries rise in the highlands some 20 miles or more inland. The valleys of several of its eastern tributaries-Little, Anvil, and Glacier Creeks-were the sites of famous placer deposits that became wellknown to mining men throughout the world; and scores of less wellknown deposits scattered throughout the valley of almost every stream in the entire basin have contributed more or less placer gold to swell the large total that has come from this area. A low pass in the divide at the head of its northern tributary, Goldbottom, was the route in the past by which glacial ice, originating in the Kigluaik Mountains to the north, spilled over a short distance into this part of the basin of Snake River. Except for this relatively slight incursion no glaciers are known to have invaded any part of the Snake River Valley, but boulders of foreign rocks have been found in a number of places where their presence can only be explained as due to drainage changes induced by the occupation of some of the valley by ice or to other as yet little understood stream diversions.

Throughout most of the Snake River area the bedrock is predominantly composed of the very ancient schists and related rocks of the Nome group. In the vicinity of Anvil Peak, toward the southeastern limit of the drainage basin of Snake River and in the headward portions of the valley, thick much metamorphosed limestones form the principal outcrops. No granitic igneous rocks have been recognized at any place in the Snake River area, but two small tracts of granitic rocks are known within 2 or 3 miles of the northern limit of the basin, and much larger areas are known in the Kigluaik Mountains, 10 miles or so farther north. Some ancient dikes of greenstone cut the schists but apparently none of these are extensive or had significant effect in introducing mineralization that furnished gold to the placers.

Many of the streams tributary to the southern part of Snake Rivel: have a large part of their courses in the coastal plain section where the ancient beaches occur. Some of the gold from the valleys of the first eight streams listed in the following table may therefore be regarded

$262000-41-8$ 
as more closely related to those old marine deposits than to typical stream placers. The records, however, show no notable difference in the fineness of the gold from the placers of Anvil Creek, which lie outside the coastal plain area, and those on Wonder Creek, which lie entirely within the coastal plain. In fact, the extremely small range of fineness of the gold from any of the placers in the Snake River Basin is noteworthy. The only available record of fineness of gold from streams tributary to Snake River from the west is that for Monument Creek, which is 902 , or slightly higher than the general average for the whole area.

Fineness of placer gold from Snake River area, Nome district, of Seward Peninsula region

\begin{tabular}{|c|c|c|c|}
\hline Creek & $\begin{array}{l}\text { Number } \\
\text { of records }\end{array}$ & $\begin{array}{l}\text { Range of } \\
\text { fingeness }\end{array}$ & $\begin{array}{l}\text { A verage } \\
\text { flneness }\end{array}$ \\
\hline Snake River.. & \multirow{10}{*}{$\begin{array}{l}2 \\
9 \\
2 \\
1 \\
3 \\
1 \\
2 \\
1 \\
6 \\
1 \\
1 \\
1 \\
2\end{array}$} & \multirow{10}{*}{$\begin{array}{lc}886 & -8971 / 2 \\
8581 / 2-905 \\
890 & -894 \\
& 898 \\
893 & -895 \\
& 890 \\
875 & -901 \\
& 8881 / 2 \\
876 & -898 \\
& 883 \\
& 883 \\
& 902 \\
8711 / 2-872\end{array}$} & \multirow{10}{*}{$\begin{array}{r}892 \\
883 \\
892 \\
898 \\
894 \\
890 \\
888 \\
888 \\
893 \\
883 \\
883 \\
902 \\
872\end{array}$} \\
\hline $\begin{array}{l}\text { Dry } \\
\text { Newton............ }\end{array}$ & & & \\
\hline Holyoke..... & & & \\
\hline Center-..... & & & \\
\hline Wonder $\ldots . . . .$. & & & \\
\hline Little & & & \\
\hline Anvil................ & & & \\
\hline Glacier & & & \\
\hline Snow Gulch & & & \\
\hline $\begin{array}{l}\text { Monument } \\
\text { Rock }\end{array}$ & & & \\
\hline Total ....... & 32 & & 888 \\
\hline
\end{tabular}

The gold from various parts of the Snake River area differs greatly in physical characters and appearance. Some of the gold is rusty, where some is bright; some is in rather small flakes, whereas some is chunky and rather coarse. Moffit ${ }^{75}$ records the fact that the gold from Anvil Creek was rather chunky and much of it was in nuggets, especially in the vicinity of the Discovery Claim, whereas farther downstream it was in smaller pieces. It is perhaps significant to note that the largest nugget so far found in Alaska came from a bench claim east of the Discovery Claim on Anvil Creek. This nugget had considerable quartz adhering to the gold so that its gross weight was 182 ounces. The amounc of gold it contained, calculated at the old price for gold, of $\$ 20.67$ an ounce, was $\$ 2,660$. Two other large nuggets that were found near the same place were estimated to contain $\$ 1,500$ and $\$ 1,700$ worth of gold at the old price of gold. Unlike the gold from Anvil Creek, most of that recovered from Glacier Creek and its tributary Snow Gulch was in rather small, well-worn particles. Most of the gold from Rock Creek is in such fine flakes that it is difficult to recover except by the use of quicksilver.

75. Moffit, F. H., op. cit. (Bull. 533), p. 83. 


\section{NOME RIVER AREA}

Many of the features of the Nome River Valley are close counterparts of those of the Snake River area, already described, but there are several noteworthy differences between the two. Perhaps the most noteworthy is that Nome River heads well into the heart of the Kigluaik Mountains and thus traverses belts of rock that are entirely absent from the valley of Snake River. In these mountains, as already noted, there are extensive areas of granitic intrusives that cut all the older rocks and may have had an effect in introducing mineralization that contributed valuable metals to the placers, though no placers are being mined in this part of the area. These mountains were also the seat of Alpine glaciation during the Pleistocene, and the tongues of ice from them extended for some distance southward, occupying part of the area that now is tributary to Nome River. Even outside the area actually occupied by the ice the detrital material, derived by the glacial erosion, was spread out by the action of the flood of waters which resulted from the waning and final disappearance of the glaciers. Greenstone intrusives are much more numerous and occupy larger areas in the valley of Nome River than in that of Snake River. Like Snake River, the southern part of the course of Nome River traverses the coastal plain province, and some of its tributaries, noted in the accompanying table, have their valleys practically restricted to the coastal plain. Otter Creek and Tripple Creek belong to this group.

Fineness of placer gold from Nome River area, Nome district, of Seward Peninsula region

\begin{tabular}{|c|c|c|c|}
\hline Creek & $\begin{array}{l}\text { Number } \\
\text { of } \\
\text { records }\end{array}$ & $\begin{array}{l}\text { Range of } \\
\text { fineness }\end{array}$ & $\begin{array}{l}\text { A verage } \\
\text { fineness }\end{array}$ \\
\hline $\begin{array}{l}\text { Otter } \\
\text { Tripple } \\
\text { Osborn } \\
\text { Nome River near Dexter } \\
\text { Deenter- } \\
\text { Left Fork of Dexter } \\
\text { Grouse Gulch }\end{array}$ & $\begin{array}{r}1 \\
1 \\
2 \\
17 \\
2 \\
3 \\
2\end{array}$ & $\begin{array}{r}889 \\
873 \\
8751 / 2-893 \\
18251 / 2-883 \\
882-905 \\
8951 / 2-8981 / 2 \\
896-8961 / 2\end{array}$ & $\begin{array}{r}889 \\
873 \\
884 \\
1862 \\
893 \\
897 \\
896\end{array}$ \\
\hline Total & 18 & & 880 \\
\hline
\end{tabular}

1 Only one record less than 854 .

The fineness of gold recorded in the preceding table does not differ greatly from that reported in earlier pages as being in general characteristic of the gold from the beaches or from the Snake River area. The widest divergence is of the gold from placers at the junction of Nome River and Dexter Creek, which averages nearly 20 points less than the average for the area. Some doubt is felt as to the correctness of the one record of gold from this place that is given as $8251 / 2$ fine, for this is nearly 25 points lower than that for any other deposit 
in the area. On the other hand, even if that record is excluded the other six records from this same locality indicate gold about 869 fine, still considerably lower than the average for the other parts of the area. Moffit notes that the gold from Osborn Creek, a tributary from the east to Nome River, is coarse and bright and most of it is smooth and well rounded. Small nuggets weighing as much as an ounce or so have been fairly common in its placers.

\section{CAPE NOME AREA}

The rocky headland, Cape Nome, that juts out to the shore line some 12 miles east of Nome presents some geologic features unlike those found in any other parts of the Nome district. For an area of several square miles at and adjacent to the cape the country rock is an old granite mass unlike the granites referred to in earlier pages as occurring in the Kigluaik Mountains. The relation of this granite to the nearby metamorphic sediments is so obscure that it has not yet been satisfactorily determined whether the granite has been intruded into the schists or the old sediments laid down on top of the granite. This rocky headland seems to have stood for a long time, a prominent point against which the sea beat and seaward of which no coastal plain is found. To the west, however, forming a tapering tract that widens to the west, occurs a coastal plain comparable to that already described in the Nome River area. Rising in the hills north of this plain are a number of small streams whose valleys are partly cut in the old hard rocks and partly in the unconsolidated coastal plain deposits.

Records are now available to the Geological Survey from only two. of the valleys of small streams in this area, namely, Hastings Creek and Alma Gulch. Three records of the fineness of gold from Hastings Creek show a range of 842 to 878 and an average of 858 . One record of gold from Alma Gulch shows a fineness of 872 . These records indicated a much lower fineness than that for most of the stream and beach placers of the Nome district, but the fineness of the gold from Alma. Gulch is not greatly different from the fineness of gold from the Second Beach, in the vicinity of Nome, namely 876 . This is not strange, as the Second Beach has been recognized as a topographic feature in the vicinity of Hastings Creek, as well as at a number of intervening points between Nome and the Cape.

\section{OREGON AREA}

Although some placer mining has been done at a number of places in the part of the Nome district that lies west of the Snake River area, the production of gold has been small and the various camps have not been examined with the degree of thoroughness that has been given to the more productive camps. In general this western area is comparable 
to the other parts of the Nome district in that the bedrock is dominantly formed of the old sedimentary members of the Nome group, with some subsequent intrusions of the members of the greenstone igneous group but without any known occurrences of the granitic intrusives.

The only record of the fineness of gold from this western area is a single report from Oregon Creek, ${ }^{76}$ a tributary of Cripple River that enters Bering Sea some 12 miles west of Nome. The headward portion of the valley of Oregon Creek is carved mainly in a large tract of metamorphic limestone, but the lower or western part of this valley has for its bedrock chloritic schist. The gold is described as fairly coarse, but the grains are usually well-rounded and bright. Some nuggets of bismuth are recovered in the concentrates from these placers. Both creek and bench placers occur in the valley of Oregon Creek. In the overburden of the bench deposits are found some large boulders or rocks foreign to the drainage basin, such as granite and gneiss. The single record of the fineness of gold from this area is 899 . This is closely similar to the fineness.recorded for most of the placers in other parts of the Nome district.

\section{PORT CLARENCE DISTRICT}

The Port Clarence district lies some 50 miles or more northwest of Nome and takes its name from the nearby landlocked body of water that affords practically the only protected harbor on the entire coast of Seward Peninsula. Placer mining in this district has centered in the past in two principal areas-one to the northeast and the other to the southeast of the arm of Bering Sea. The principal town in the district is Teller, on the southern shore at the head of Port Clarence. This name has been adopted to designate the entire area lying south of the town, and the name Agiapuk has been adopted for the northern area, which lies principally in the valley of Agiapuk River. Formerly there was some gold placer: mining in the country still farther northwest of Teller, but this has been practically discontinued of late years, and no accurate records of the fineness of the gold that occurs in the placers of that more remote area are now available to the Geological Survey.

In general, the geology of the Port Clarence district is comparable with that of some of the districts in other parts of Seward Peninsula, notably Kougarok, Nome, and Fairhaven. The bedrock throughout the eastern part of the district is composed of highly metamorphic schists of the Nome group, but to the north and west are the very extensive areas of limestone belonging to the so-called Port Clarence limestone, of Ordovician and Silurian age. Southeast of Port Clar-

\footnotetext{
${ }^{78}$ Collier, A. J., Hess, F. I., Smith, P. S., and Brooks, A. H., op. cit. (Bull. 328), pp. 211$215,1908$.
} 
ence Bay are innumerable intrusions of greenstone cutting the schists. Many of the hills to the north of Teller are capped by basaltic flows that were evidently poured out in Tertiary or later times. Other than the greenstones and basalts no igneous rocks are known to occur in the district though some 25 miles southeast of Teller, in the Kigluaik Mountains, granitic intrusives are common and have considerable areal extent.

\section{TELLER AREA}

The principal placer deposits in the Teller area have been found in the valleys of Bluestone River and its tributaries, especially Gold Run. Smaller deposits, however, have been mined at a number of other places within a radius of 10 miles of Teller, especially in the valleys of Dese and Coyote Creeks, which enter Grantley Harbor some 7 and 2 miles, respectively, east of the town. The deposits in the valley of Bluestone River belong to two distinct types, namely, creek and bench placers. The gold recovered is generally dark and much of it is stained with an iron coating. In the vicinity of the placer diggings numerous greenstone bodies in the form of sills or dikes intrude the chloritic and graphitic schists and presumably had some effect on the mineralization that supplied gold to the placers. This relation is shown by the fact that a number of nuggets have been found in which the gold is adhering to and intercalated through pieces of the greenstone. Most of the gold is in fairly large pieces; in fact, during the season of 1936 on one property a nugget weighing $221 / 4$ ounces, 2 of 121/4 ounces, and 12 weighing more than 5 ounces each were recovered in the course of the year's work. ${ }^{77}$ The large boulders of resistant greenstone that are abundant in many of the streams form natural barriers that are excellent places for the lodgment of gold and for protecting the gold against the usual wear caused by stream transportation. It is in such "pockets" that the larger nuggets are found and that rich concentrations occur.

From placers near the junction of Right Fork and Bluestone River Smith ${ }^{78}$ recorded the fact that in a lot of gold worth more than $\$ 1,000$ almost all the smaller pieces were shotlike in form and uniformly bright in color. Some wire gold occurred in this lot, one piece being nearly 2 inches long. The largest nugget was worth about $\$ 72$ at the old price of gold. None of the pieces of gold showed signs of long travel, and several pieces could only have come from nearby localities.

Five records of gold from the placer deposits of the Gold Run Valley show a range of 880 to 892 and an average of 885 . It is perhaps

$\pi$ Smith, P. S., Mineral industry of Alaska in 1936: U. S. Geol. Survey Bull. 897-d, p. 64,1938 .

${ }^{78}$ Smith, P. S., Recent developments in southern Seward Peninsula, Alaska: U. S. Geol. Survey Bull. 379, pp. 297-300, 1909. 
significant that of two lots of gold obtained from the same clean-up, one of which consister exclusively of nuggets and the other of the smaller particles, the fineness of the nuggety lot was 892 and of the other lot 880 , which is exactly the reverse of what would have been expected theoretically. One report from placers dredged on. Dese Creek gave a record of 902 for the fineness of the gold. The foregoing six analyses show an average for the area of about 888 , which is rather close to that shown by the records of the gold from many of the other Seward Peninsula areas.

\section{AGIAPUK AREA}

Immediately north of Teller a number of small streams emptying directly into Grantley Harbor have been the scenes of some placer: mining in the past. Of these the most productive has been Sunset Creek. Practically no mining in the valleys of any of these streams is now in progress, and as no records of the fineness of their gold are now available to the Geological Survey they may be dismissed without further comment.

Agiapuk River drains an area several hundred miles in extent, but at few places within it have placers of economic importance been found, and for those few no records of the fineness of the gold are available except for deposits on Swanson Creek. Swanson Creek is a southern small tributary that heads in the hills of the watershed between the streams that flow south direct into Grantley Harbor and those that flow north to join Agiapuk River. Much of the bedrock in the valley of Swanson Creek consists of the massive, somewhat metamorphosed limestone of Silurian and Ordovician age near its contact with the older schists and slates of the Nome group. On the whole the bedrocks in the valley of Agiapuk River seem to be somewhat less heavily metamorphosed than the rocks elsewhere that are correlated with them. Furthermore, there seems to be much less mineralization in the form of quartz veins and stringers than in the more productive placer areas of the peninsula.

The two available records of the fineness of the gold from placers on Swanson Creek show a range of 888 to 892 and an average of 89.0. This is practically identical with the record of the fineness of the placer gold from the Teller area to the south, though, as noted, many features of the geology of the two areas show rather striking. differences.

\section{SOLOMON DISTRICT}

Some 30 miles nearly due east of Nome and 20 miles west of Bluff is the small settlement of Solomon, which long served as the center for a placer mining area that extended for 25 miles inland to the north and 10 miles or so to the east and to the west. At various 
times in the past productive placer mining has been in progress on almost every one of the streams, large or small, within this district, but of late years activity has dwindled until at only a few sites is mining now being carried on.

The general geology of the district was surveyed by the Geological Survey many years ago during the time that mining was active, and the report of that work has been the basis for most of the following statements. ${ }^{79}$ The southern part of the district consists of a tract of coastal plain that tapers eastward from a width of more than 5 miles in the vicinity of Solomon until it is entirely cut out near Topkok Head. To the north this plain is succeeded by broken hills, some of whose summits rise to heights of more than 2,000 feet above the sea. A wide variety of different kinds of sedimentary rocks crop out on these uplands, but all of them are considered to be of early Paleozoic age or oldier. These sedimentary rocks consist mainly of highly metamorphic micaceous and chloritic schists and massive recrystallized limestones. The schists, especially, include many quartz veins and lenses. In a broad way these sedimentary rocks may be correlated with the so-called Nome group, of which they were originally considered a part. Intruding the older members of the sedimentary sequence are sheared basic intrusives of greenstone habit. There is also an old series of metamorphic rocks that are interpreted as having originally been formed through igneous processes and subsequently metamorphosed. Some: mineralization seems to have accompanied the intrusion of the greenstones, but so far as known there was none attendant on the formation of the rocks that now appear as metamorphic equivalents of original igneous rocks. Mineralization, however, is widespread in all the areas occupied by the sedimentary rocks, not only as distinct veins and stringers but in the form of broadly disseminated deposits not directly traceable to any specific source.

The placers of the Solomon district group themselves into three rather distinct areas-those that lie in the basin drained by Solomon River and its tributaries, those that lie in the basin of Casadepaga River or its tributaries, and those that occur in or near the coastal plain area and that will here be referred to as in the Spruce Creek area. Solomon River discharges into Norton Sound, but Casadepaga River lies to the north of the Solomon River Valley and discharges into Niukluk River, on which Council is situated; that stream, by devious courses and under a different name, finally empties into Golofnin Sound some 35 miles east of Solomon. The Spruce Creek area lies less than 8 miles in an east-northeast direction from Solomon.

\footnotetext{
${ }^{7}$ Smith, P. S., Geology and mineral resources of the Solomon and Casadepaga quadrangles, Seward Peninsula, Alaska : U. S. Geol. Survey Bull. 433, 234 pp., 1910.
} 
Although the coastal plain deposits form benches along the sides of the valley of Solomon River for nearly 6 miles above its mouth, the stream has incised its course through them so that bedrock is exposed in the valley walls at intervals all the way northward from a point only 2 miles inland from the coast of Norton Sound. In this part of its course there is strong likelihood that the gold now found in the stream placers may have come from both the overlying gravel deposits and the nearby bedrock sources. Throughout the rest of the valley it seems certain that the placers were formed primarily by normal stream and weathering processes and the gold came from nearby local mineralization. No evidence of glaciation has been recognized in any part of the valleys of Solomon River or any of its tributaries.

In the following table the available records of the fineness of the gold in different parts of the basin of Solomon. River have been listed. Unfortunately no reports are available as to the gold from the placers near the head of Solomon River, as for instance from Coal Creek, where at one time considerable dredging was done.

Fineness of placer gold from Solomon River area, Solomon district, of Seward Peninsula region

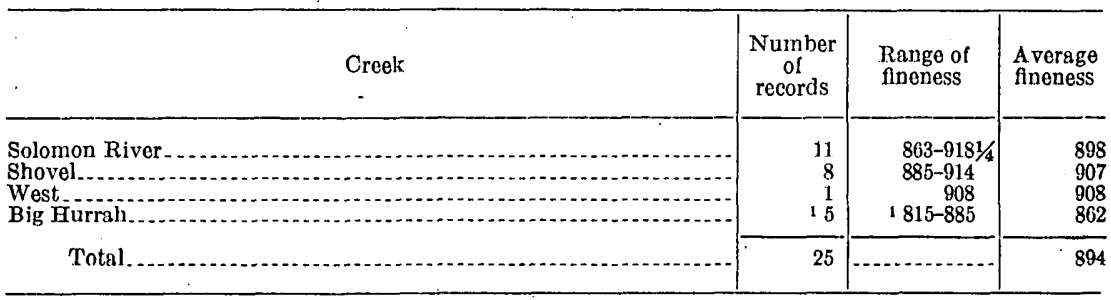

1 One record only below 858 .

Smith ${ }^{80}$ gives considerable information regarding the character of the gold in the Solomon River Valley in the vicinity of Jerome Creek, about 4 miles north of Solomon. He quotes the operator of the dredge that was mining at this place to the effect that most of the gold recovered there was in small flakes but not "flour" gold and appeared similar to the usual flaky fine river gold. The operator further stated:

I would judge that 95 percent of the gold we get by the dredging process is in smaller pieces than 3 grains in weight. Out of a clean-up of $\$ 10,000$, I would estimate that there would be $\$ 40$ to $\$ 50$ in nuggets weighing from $\$ 1$ to $\$ 12$ each [at the old price of gold]. The nature of the nuggets is rough and scraggly.

About 1 percent of the gold recovered at this place was said to be very smooth washed gold that looks as though it had been carried a long distance from its point of origin.

${ }^{80}$ Smith, P. S., op. eit. (Bull. 433), pp. 160-161. 
The low tenor of some of the gold from Big Hurrah Creek is perhaps to be ascribed to its having been derived from the mineralized zone adjacent to the Big Hurrah lode gold mine, which is the only lode mine in Seward Peninsula that has been developed extensively. It should be noted, however, that only one of the records from the Big Hurrah Valley shows gold lower than 858 , so that if that low record is excluded the average fineness of gold from the other parts of the valley would become 874 instead of 862 , as stated in the table. In comnection with the one low record of 815 from the placer deposits of Big Hurrah Creek, it should be noted that this determination was made of nuggety material selected from the general run of the cleanup and the rest of the material that was not nuggety had a fineness of 858. No satisfactory explanation can be offered for the rather high fineness of the gold from Shovel Creek and its tributary, West Creek. Limestone is perhaps more common in this drainage basin than elsewhere in the Solomon River area, but otherwise the geologic features in both tracts seem closely comparable.

\section{SPRUCE CREEK AREA}

Although resembling in its general physical aspects the coastal plain near Nome, that in the Solomon district differs in the important feature that so far no comparable extensive old beaches that carry rich amounts of gold have been found in it. At places beach material has been disclosed in pits that have been sunk by the miners, but in general the coastal plain deposits in the vicinity of Solomon are composed of detritus brought in by streams or of deposits formed in lagoons that do not appear to have been subjected to strong sorting by waves and shore processes. In the vicinity of Spruce Creek is practically the only place where any notable amount of gold has been worn from deposits that might be classed in part at least as of beach origin. Even here the placers that have been worked partake more of the character of deposits formed by streams and slightly reworked by the sea than of typical beach deposits. In the course of miniing as the work was carried farther and farther into the more constricted portions of the valley of Spruce Creek the deposits took on increasingly the characteristics of normal stream placers.

Most of the mining in the Spruce Creek area was done subsequent to the examinations by geologists of the Geological Survey so that information as to the detailed geologic facts disclosed by those later developments are lacking. Four reports of the fineness of the gold from the placers in the valley of Spruce Creek are now available to the Geological Suivey. These show a range of about $8893 / 8$ to $8952 / 5$ and an average of about 891 . The average fineness of the gold from the beaches at Nome was approximately 898 . The somewhat lower fineness of the gold from the Spruce Creek area perhaps is mainly due 
to the records relating more to gold from stream deposits in the area than to gold from true beach deposits.

\section{CASADEPAGA AREA}

In the early days of mining in Seward Peninsula there was considerable prospecting and development work in progress at a number of places in the valley of the main Casadepaga River and in the valleys of practically all of its tributaries. These activities have gradually dwindled until of late years, except for the operation of one dredge and a little prospecting, the whole area has become almost deserted.

The geology of the Casadepaga area is in many respects essentially comparable with that of the Solomon River area, which joins it on the south. The general trend of the bedrock in the two areas is in a northerly direction so that the same general sequence of rock formations appears in each and has been subjected to essentially identical processes. The northern part of the Casadepaga area, however, lies not far distant from and to the south of the Bendeleben Mountains, which were the scene of extensive valley glacieis in the Pleistocene. Although none of these ice tongues actually invaded any part of the Casadepaga area their proximity to it did have an indirect effect, especially during the period when the glaciers were melting and distributing great sheets of gravel over and beyond the country the ice had once occupied. The Bendeleben Mountains were also the site of numerous intrusions of granitic masses in the geologic past. These granites may have been contemporaneous with some of the intrusive activities that resulted in mineralization of the adjacent schists.

The only reports that are now available to the Geological Survey of the fineness of gold from deposits in the Casadepaga area come from placers near the central part of the river valley in proximity to Ruby Creek," which is close to: the point where the old road from Solomon, which crosses the divide at the head of Solomon River, first comes to Casadepaga River. Five reports of gold from this part of the "Casadepaga River Valley show a range in fineness of 901 to 922 and an average of 909 . This average is not far different from that in the Iron Creek area of the Kougarok district, which is not at all surprising as the streams tributary to Iron Creek rise in the highland from the eastern slopes of which the water flows into the drainage basin of Casadepaga River, whereas the water that flows north and west is tributary to Iron Creek. The fineness of the gold from the Casadepanga area is also not greatly different from that of the Taylor Creek area in the Kougarok district, though parts of these two areas lie more than 50 miles distant from each other. 


\section{NORTHWESTERN ALASKA REGION}

In spite of the enormous extent of northwestern Alaska the output of placer gold has been less than that from any of the other Alaska regions. This condition probably has resulted more from the remoteness of the region than from the absence of deposits carrying gold. True, the difficulties of access, the short working season, and the costliness of operations there necessarily require that such deposits as can be worked profitably shall on the whole be richer than those in a region where these other handicaps are less severe. The finding of particles of gold in the deposits of many of the streams in remote parts of the region is constantly being reported, but the only areas in which significant amounts of placer gold have been found are in the valleys of Noatak and Kobuk Rivers. It seems extremely doubtful whether the geologic conditions throughout the vast territory north of the Brooks Range are suitable for the accumulation of placers that will repay the cost of exploration and development. This conclusion is drawn because the general bedrock and other geologic features are not such as are found in any of the known productive placer regions of the Territory.

The geology and mineral resources of northwestern Alaska have been described and mapped by Smith and Mertie ${ }^{81}$ in a report issued by the Geological Survey.

The deposits in the valley of Noatak River have never been mined in any continuous fashion, and the reports of the occurrences are so vague that they rest on little more than hearsay tales. Such information as is available regarding the deposits in the Noatak Valley has been given in reports by Smith. ${ }^{82}$ Gold from deposits near the head of the Noatak Valley is said to be notable for its coarseness and for absence of flaky pieces. In form it was said to be worn and flattened so that it resembled pumpkin seeds and had a reddish color. At the old price of gold (\$20.67) it was reported to be worth $\$ 19.20$ an ounce, which would indicate that it was at least 925 fine. These records, however, are so indefinite that they have not been included in any of the tables accompanying this report and will not be discussed further.

\section{KOBUK DISTRICT}

The Kobuk district is the only part of northwestern Alaska in which gold placers that have been productive and that doubtless will continue for a long time to be worked are known, and for which rec-

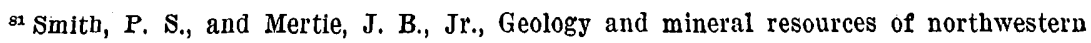
Alaska : U. S. Geol. Survey Bull. 815, 351 pp., 1930.

82 Smith, P. S., The Noatak-Kobuk region, Alaska : U. S. Geol. Survey Bull. 536, pp. 13a$142,1913$.
} 
ords as to the fineness of the gold contained in them are available for the purposes of the present study. Although the occurrence of placer gold has been known at a number of places within the limits of the Kobuk Valley, there are two principal areas in which mining has been especially active. These are in the vicinity of Shungnak and near Kiana. The Shungnak area is some 150 miles in an air line east and upstream from the mouth of Kobuk River, and the Kiana area is some 4.0 miles east of the mouth of the Kobuk.

\section{SHUNGNAK AREA}

The placers of the Shungnak area that have been mined lately are rather closely restricted to the valleys of the small streams that rise in the Cosmos Hills immediately north of the lowland of Kobuk River and not far from the settlement of Shungnak or are in the valleys of such larger streams as Kogoluktuk and Shungnak Rivers in that part of their courses where they or their tributaries traverse these hills. The general bedrock throughout this part of the valley consists of black slate and schist and some massive beds of lime. stone cut by numerous small veins and stringers of quartz. The age of these rocks has not been determined with precision, but it is believed that the schists are not younger than the early Paleozoic, with strong possibility that they may even be pre-Paleozoic. The limestone is probably somewhat younger than most of the schists. Some basic igneous rocks of greenstone habit cut the schists and limestones and have themselves been subjected to mountain-building forces by which they have been greatly sheared and have lost many of their original characteristics. None of these greenstones have been proved to have been connected with valuable mineralization in their vicinity nor to have contributed gold to the placers. During the Pleistocene most of the mountainous area to the north of Kobuk River was covered with ice, and glacial tongues extended down the valleys of all the larger preexisting streams and even deployed into the lowland of the Kobuk River. The effect of these ice streams was to scour out and remove much of the old detrital material in the larger valleys. As a result, some of the placers that are now being mined are remnants of old deposits that were not destroyed by the glaciers; others have been formed subsequently, either through the weathering that has broken down the bedrock or through resorting by present streams of the material that had been spread out over parts of the country when the glaciers waned and melted away.

The only specific records of the fineness of gold from the Shungnak area relate to material from Dahl Creek, which is a small stream fiowing directly into the Kobuk, and from Iynx and Boulder Creeks, which are tributaries of Kngoluktuk River. The gold from Dahl 
Creek was described by Smith ${ }^{83}$ as reddish to brassy yellow in color, occurring in small pieces that were somewhat spongy and had sharp irregular outlines. A little wire gold is found, but it is not common. Several good-sized nuggets weighing as much as 35 ounces have been recovered, and many of them have quartz adhering to the gold as though they had been freshly broken out of the original vein. Determination of the fineness of five lots of gold from Dahl Creek showed a range of 772 to 834 and an average of 805 . Five determinations of the fineness of gold from Boulder and Lynx Creeks showed a range of $8251 / 2$ to 830 and an average of about 828 .

Although no specific records are available as to the fineness of the placer gold from Shungnak River, some 15 miles west of the town of Shungnak, it may be of service to cite here certain statements regarding the general character of the gold from that place. ${ }^{84}$ The gold is said to be reddish, and though not rusty it is not bright and shiny but has a dead luster. Its shape is quite characteristic in that it looks like shot that have been flattened under the hammer and is often spoken of by prospectors as "pumpkinseed" gold. Silver nuggets are very common in the concentrates recovered in the course of the gold mining. Although nuggets weighing as much as 2 ounces or more have been found in these placers most of the gold is in small pieces worth from a fraction of a cent up to 5 cents. The value of the gold is reported to be $\$ 16.70$ an ounce, at the old price of gold. This suggests that its fineness is about 800, but inasmuch as it is not known whether or not the quoted price is based on the true value of the bullion or includes certain handling and treatment charges, 800 has not been considered accurate enough to be included in the records that have been given in the tables accompanying this report. .

\section{KIANA AREA}

The principal placer mining claims in the Kiana area are on tributaries of Squirrel River, some 8 to 10 miles north of the settlement of Kiana, on Kobuk River. This area has not been visited by any members of the Geological Survey since 1910 so that little specific information is available as to the more recent developments except that within the past few years there has been a greatly increased output of gold through the operation of a well-mechanized modern mining plant. Much of the bedrock in the Kiana area is schist and associated contorted and metamorphosed limestone. These rocks are probably comparable in age with certain of the schists and limestones of the placer areas in Seward Peninsula. As described by Smith, ${ }^{85}$ the gold from different claims differs decidedly in, its physical characteristics. Thus

\$ Smith, P. S., op. cit. (Bull. 536), p. 128.

84 Smith, P. S., op. cit. (Bull. 536), p. 132.

85 Smith, P. S., op. cit. (Bull. 536), pp. 135-137. 
the gold from one of the claims on Klery Creek was described as occurring mainly in pieces, few of which were worth less than half a cent each at the old price of gold. In color the gold was described as dark but never with a black coating, and although its corners were somewhat rounded it evidently had not traveled far. A number of pieces had fragments of the vein material and country rock with which the gold had been associated still adhering. On the other hand, only a short distance upstream from the locality in which the gold was of the character described the gold was practically all in bright scales and in such small pieces that almost no pieces worth more than a few cents each were found in several hundred ounces of clean-up. None of the pieces had foreign material attached to them, and the whole appearance was that of what is often referred to by prospectors as "bar" gold. The gold seems to have been subjected to much further transportation from the ledge in which it originated than the other gold, and its fineness was appreciably higher. Still farther upstream the gold is reported to have been nuggety. The obvious explanation of such variations in the character of the gold from different claims is that it is of extremely local derivation and that a number of mineralized areas are traversed by the stream in whose valley the placers occur.

In addition to the old report of 888 for the fineness of the placer gold in the valley of Klery Creek there is a recent report from the same general area that records a fineness of $9171 / 2$. The average of these two records is approximately 903 . In view of the spread between the records and the known variation in the character of the gold from nearby parts of the area the small number of records available for comparison makes the average given of little precise significance. It does serve, however, to indicate a marked difference between the gold from the Kiana area and that from the Shungnak area and suggests comparison with certain of the higher-grade golds from some of the Seward Peninsula areas, such as the Inmachuk area, in the Fairhaven district, or perhaps the Taylor area, in the Kougarok district. 



\section{N D E X}

A

Abstract.

Aggie Creek.

Agiapuk area

Albert Creck

Albion Gulch

Alder Creek.

Alma Gulch

Amalgam, definition of.

A merican Croek (Hot Springs district) - - -

A merican Creek and vicinity (Eagle (district).

Amy Creek

Aniak area 159,233

Antimony, occurrence of

Anvil Creek

Archibald Creek

Arolic area.

Arolic River.

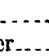
$160,235-236$ 236

B

Baruey Creek

Basin Creek

Beach depocits near Nome--

Bear Creek (Fairhaven district) ----2---

Bear Creek (Goodnews district) ........... 234, 235

Bear Creek (Ruby district) .................. 221

Bear Creek (Tuluksak-Aniak district) ......... 232

Big Hurrah Creet....................... 261, 2652

Bíreh Creek (McKinley district) ............. 227

Birch Creek area above Crooked Creek (Circle district) . . . . . . . . . . 157, 185, 187-188

Birl Creek................................. 176

Bismuth, occurrence of ..................... 257

Bluestone River............................ 258

Bluff district. ... . . . . . . . . . . . . . . . 160, 237-238

Bonanzs area.................. 158. 207

Bonanza Creek (Chisana district) . . . . . . ..... 184

Bonanza Creek (Circle district) .............. 187

Bonanza Creek (Koyuk district) . . ........... 250

Bonnifleld district . . . . . . . . . . . . . . 157, 179-182

Bottom Dollar Creek........................ 188

Boulder Creek (Circle district) . . . . . . . . 187

Boulder Creck (Kobuk district) . . . _. _ _. . . 265-266

Boundary Creek ........................ 190

Broken Neck Creek. ......................... 190

Buckland area........................ 160, 241, 243

Buckskin Creek........................... 199

Bullion, computation of value of ........ 150-151

metals in . . . . . . . . . . 164-165

Butte Crcek (Circle district).................. 188

Butte Creek (Goodnews district) ............ 236

\section{C}

Cache Creek (Hot Springs district). 204-205

Cache Creek (Yentna district)

Cache Creek area
47 Can area . ..................... 160, 241-242

Candle Creek (Fairhaven district)............. 242

Candle Creek (McKinley district) .............. 228

Canyon Creek (Tuluksak-Aniak district) ..... 233

Canyon Creek (Yentna district) ........... 170

Cape Nome area. .................. 161, 251, 256

Caribou Creek. . . . . . 197

Casadepaga area................... 161, 260, 263

Casadepaga River......................... 263

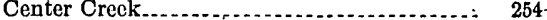

Chandalar district..................... 157, 182, 183.

Chatanika area.................... 157, 192, 193-194

Chatanika River......................... 194

Chatham Creck.......................... 194

Chathenda Creek. . . . . . . . . . . . . . . ......... 184

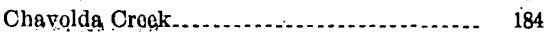

Chechako Gulch........................... 176

Chena-Salcha area............... 157, 163, 192, 196-197

Chicago Creek.............................. 204

Chicken Creek (Fortymile district)........... 201

Chicken Creek (Iditarod district) ............. 207

Chisana district. . . . . . . . . . . . . . . . . . . 157, 184

Chistochina district . . . . . . . . . . . . . . . . 156, 169-171

Chititu Creek...

Cinnabar, occurrence of . . . . ............... 170

Circle district. . . . . . . . . . . . . . . . . . 157, 164, 184-189

Clean-up, definition of ..................... 150

Cleary Creek...................... 194

Coal'Creek. See Woodchopper-Coal Creek area.

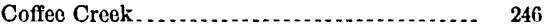

Coffee Dome area . . . . . . . . . . . . . . . . . . 160, 246

Cook Inlet-Susitna region .......... 156-157, 172-177

Copper, occurrence of . . . . . . . . . . . . . . 170,172

Copper River region.... . . . . . . . . . . . . 156, 169-172

Council district.................... 160, 162, 238-240

Coyote Creck... . . . . . . . . . 258

Cripple area....................... 158, 208, 210-211

Cripple Creek (Fairbanks district) . . . . . . . . 195

Cripple Creck (Innoko district) . . . . . . . . . . . . 210

Crooked Creck (Council district) ............ 240

Crooked Creek (Eagle district) ............... 190

Crooked Creek (Kantishna district) .......... 213

Crooked Creek (Nelchina district) ........... 172

Crooked Creek area................ 157, 164, 185-187

Crow Creek............................. 174

Cub Creek . . . . . . . . . . . .

Cunningham Gulch........................ 243

\section{$\mathrm{D}$}

Dahl Creek (Kobuk district) . ........... 265-266

Dahl Creek (Kougarok district) ............. 246

Dan.Creck . . . 171-172

Deadwood Creek........................... 187

Deep Creek . . . .

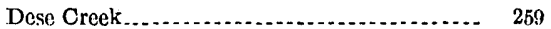

Dexter Creek. 


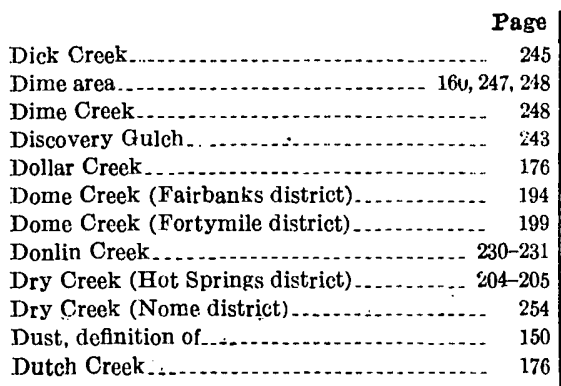

\section{$\mathbf{E}$}

Eagle Creek.

Eagle district

Elephant Creek ........................... 216

Enginecr Creek................................ 193

Esperanto Creek. . ......................... 210

Ester area......................... 157, 192, 195-196

Ester Creek................................ 195

Ester Dome ............................. 195

Eureka area $. . . \ldots \ldots \ldots \ldots . . . . . . . . . .158,202,203-204$

Eureka Creek (Hot Springs district) ........... 204

Eureka Creek (Kantishna district) ........... 212

Evia Creek ................................ 195

\section{F}

Fairbanks Creek

196

Fairbanks district $157,163,191-198$

Fairhaven cistrict.................... 160, 240-244

Faith Creek............................... 195

Falls Creek

Fanny Gulch ............................. 224

Fay Creek $\ldots \ldots \ldots \ldots \ldots$ 162, 215

Fineness of gold, definition of ............... 148-149 differences in .................. 162-164, pl.3

factors affecting

general summary of ..................... 154-161

See also individual areas.

First Creek.

Fish Creek (Fairbanks district) . . .

Fish Creek (Yentna district) ............. 177

Fish Creek area . . ...................... 157, 192, 196

Fish River area . . . . .................... 160, 162, 240

Flat Creek (Iditarod district) ................. 206

Flat Creek (Ruby district) ................ 221

Fortuna area.......................... 159, 215,216

Forty-five Gulch ........................ 199

Fortymile district............. 158, 198-201

Fortymile River area .................. 158, 198-199

Fourth of July Creek area_.......... _ _ _ 157, 189, 191

Fox Creek (Eagle district)................... 190

Fox Creek (Fairbanks district) _............. 193

Franklin Creek.

\section{G}

Ganes Creek

209

Geology of the area. See individual areas.

Georgetown district . . . ................ 159, 229-231

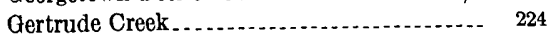

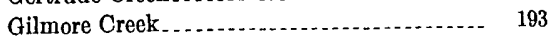

Girdwood district. ...................... 156, 173, 174

Glacier Creek (Chisana district) ............... 184

Glacier Creek (Fairhaven district)
Page

Glacier Creek (Nome district) ................ 254

Glen Gulch (Hot Springs district) ............. 204

Glen Gulch (Tolovana district) ............... 224

Gold, computation of value of . . . . . . . . . 150-151

fineness of, definition of ................ 148-149 differences in .................. 162-164, pl. 3 factors affecting .................... 165-166 general summary of................... 154-161

production of ..................... 173, 191, 236 ratio of, to other metals.......... 147-148, 164-165 separation of ............................ 140-150 See also individual areas.

Gold Creek

Gold Hill Creek........................... 195 Gold Hill district...................... 158, 201-202

Gold King Creek............................ 181

Gold Run (Chisana district) ................. 184

Gold Run (Port Clarence district) ........... 258-259

Gold Run Creek (Hot Springs district)....... 204

Goldstream area......................... 157, 192-193

Goldstream Creek.......................... 193

Goodnews district..................... 160, 234-236

Goodnews River area........................ 160, 235

Gopher Creek............................. $\quad 176$

Granite Creek (Iditarod district) . ........... 206

Granite Creek (Ruby district) ............... 221

Grant Creek............................... 201-202

Greenstone Creek . . .......................... 221

Grouse Gulch........................... 255

Grubstake Creek......... 180-181

\section{H}

Half Dollar Creek.......................... 188

Hammond River.......................... 215

Happy Creek................................ 207

Harris Creek . . . .

Harrison Creek, North Fork of .............. 188

Hastings Creek............................ 256

Heine Creek........................................... 224

Henry Creek.................................. 245

Hidden Creek

Hodzana area............................... 157, 182, 183

Hodzana River............................ 183

Holmes Gulch ............................ 227

Holyoke Creek . . . . . . . . .

Homestake Creek (Bonnifield district) ....... 180

Homestake Creek (Fairbanks district) ......... 195

Hope area . . . . . . . . . . . . . . . . . . . 156, 173-174

Hot Springs district. . . . . . . . . . . . . . . . . 158, 202-205

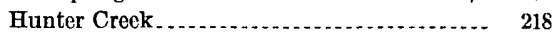

Iditarod district. . .............. 152-153, 158, 205-207

Illinois Creek ............................ 201-202

Independence Creek....................... 187

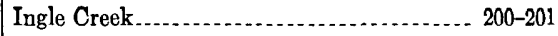

Inmachuk area.................. 160, 241, 242-243

Inmachuk River . . . . . . ................... 242-243

Innoko district . . . . . . . . . . . . . . 158, 207-21.1

Iron Creek area .................. 160, 244, 246-247

Johnson Creek .......... 184

Julian Creek

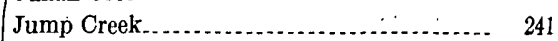

Juneau district. . . . . . . . . . . . . . . 156, 166, 167-168 
Kako area

Kantishna district............... 158, 164-165, 211-213

Kenai district. .......................... 156, 173-174

Kenai River................................ 174

Ketchem Creek............................. 187

Kiana area....................... 161, 265, 266-267

Kiwalik area....................... 160, 241, 243-244

Klehini River Valley .......................... 168

Klery Creek................................. 267

Kobuk district. . ......................... 161, 264-265

Kodiak Island............................... 178

Kokomo Creek..................... 194

Kolmakof area........................... 159, 229, 231

Koopuk Creck............................. 243

Kougarok district. ...................... 160, 244-247

Kougarok River............................. 245

Kowkow Creek............................. 236

Koyuk district......................... 160, 247-250

Koyukuk district....................... 158, 213-215

Kuskokwim region. ............. 159-160, 162, 225-236

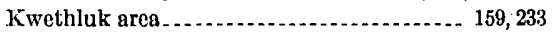

\section{$\mathbf{L}$}

Lake Creek.

Little Creek (Innoko district)

Little Creek (Nome district) . . . . . . . . . . . ........ 254

Little Delta area . . . ...................... 157, 181-182

Little Eldorado Creek (Chisana district) ...... 184

Little Eldorado Creek (Fairbanks district) ... 194

little Minook Creek ........................... 218

Little Moose Creek........................... 213

Little Squaw Creek......................... 183

Livengood area.......................... 159, 223-224

Livengood Creek.............................. 224

Lone Pine Gulch ............................. 178

Long Creek.................................. 221

Lost Chicken Creek........................ 200, 201

Iynx Creek .............................. 265-266

\section{$\mathbf{M}$}

MeCaskey Bar

McGrath area. $159,226,228$

McKinley Creek ........................... 168

McKinley district. ................... 159, 162, 226-229

Macklin Creek............................ 245-246

Malamute Gulch........................... 206-207

Mammoth Creek........................... 187

Marguerite Creek........................... 180

Marshall district. . . ..................... 159, 215-217

Marvel Creek.............................. 233

Mason Creek............................... 201-202

Mastodon Creek.......................... 187

Melsing Creek............................ 240

Mertie, J. B. Jr., quoted................... 208

Metals, content of, in bullion............... 164-165 separation of .......................... 149-150

Middle Fork area ........................ 156, 170

Miller Creek............................. 187

Miller Gulch.............................. $\quad 170$

Minook area........................ 159, 162, 217-218

Minook Creek............................. 217

Monument Creek........................ 254

Moonlight Creek.
Moore Creek area.................. 159, 226, 228-229 Moose Creek (Bonnifield district) ............ 181 Moose Creek (Ruby district) ................. 222

Moran Creek ................................. 202 Mosquito Fork area .................... 158, 200 Myers Fork .................................. 201

$\mathbf{N}$

Napoleon Creek............................ 199-200 Nelchina district. . ....................... 156, 169, 172

Nevada Gulch ............................. 229

New York Creek...................... 231

Newton Creek............................ 254

Ninook area............................. 162

Niukluk area......................... 160, 239-240

Niukluk River............................ 240

Nixon Fork area.................. 159, 162, 226, 227

Nizina district........................ 156, 169, 171-172

Noatak River. . .............................. 264

Nolan Creek. . ................................ 215

Nome Creek area................... 157, 192, 197-198

Nome district........................... 161, 250-257

Nome River area................... 161, 251, 255-250

North Fork area....................... 157, 182-183

Northwestern Alaska region............. 101, 264-267

Nugget Creek (Eagle district) . . . . . . . . . . . . . . 190

Nugget Creek (Yentna district) ............. 176

\section{0}

Olive arca. .......................... 159, 223-225 Olive Creek................................. 224

Olympia Creek.................................... 235

Omega Creek ............................. 204

Ophir area............................. 158, 208-209

Ophir Creek (Council district)................ 240

Ophir Creek (Innoko district) ................. 209

Oregon area . . . . . .

Oregon Creck .............................. 257

Osborn Creek.............................. 255, 256

Otter area........................... 158, 206-207

Otter Creek (Iditarod district) ............... 206

Otter Creek (Nome district) .................. $\quad 255$

Palmer Creek................................ 197

Pan method of measuring value of placer deposits............................ 140

Patterson Creok.............................. 242

Pedro Creek ................................ 193

Peters Creek area....................... 156. 175-176

Pioneer Creek ............................... 204

Placer deposits, estimation of value of ........ 149 See also individual areas.

Platinum metals, occurrence of ..... 170, 234, 248. 249 Platte Creek ................................ 180

Poker Creek.................. 201

Poorman area..................... 159, 220, 221-222

Poorman Creek ............................ 222

Porcupine Creek (Circle district) .............. 187

Porcupine Creek (Porcupine district)......... 168

Porcupine district...................... 156, 166, 168

Port Clarence district. . . . . . . . . . . . . . 161, 257-259

Portage Creek (Bonnifield district) ......... 181-182

Portage Creek (Circle district) .............. 187

Puzzle Gulch........................... 176 
Quartz Oreek

$\mathbf{R}$

Rainy Creek area

Rampart district.

Records, character of

$170-171$ presentation of $159,162,217-218$

Rhode Island Creek................... 204

-.. 151-153

. Richardson district.......................... 159, 219

Riddle Gulch.................................. 227

Rock Creek.............................. 254

Ruby Creek (McKinley district) _............. 227

Ruby Creek (Yentna district) ................. 176

Ruby district. ........................ 159, 219-222

Ruth Creek.............................. 224

S

St. Patrick Creek

Salcha River. See Chena-Salcha area.

Seventymile area

Shamrock Creek

Sheridan Creek............................ 243

Short Creek............................. 176

Shovel Creek................................ 261, 262

Shungnak area . . . . .

Shungnak River............................. 266

Silver, content of, in bullion................ 164-165

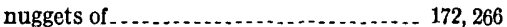

Silver Bow Basin $\ldots \ldots \ldots \ldots . . .167-168$

Skookum Creek............................ 184

Slate Creek area....................... 156, 170

Smith Creek (Fortymile district) .............. 199

Smith Creek (Koyukuk district) ............. 162, 215

Snake River area................... 161, 251, 253-254

Snow Gulch................................ 254

Solomon Creek............................. 222

Solomon district $\ldots . . . . . . . . . . . . . . . .161,259-263$

Solomon River area................ 161, 260, 261-262

Sourdough Creek............................ 194

South Fork area $\ldots \ldots \ldots \ldots \ldots \ldots$ 158, 199-200

Southeastern Alaska region............. 156, 166-169

Southwestern Alaska region................ 157,178

Spaulding Creek.......................... 209

Spring Creek............................... 215

Spruce Creek (Innoko district) ................ 209

Spruce Creek (Ruby district) ................. 221

Spruce Creek (Solomon district) ............... 262

Spruce Creek area................... 161, 260, 262-263

Squaw Creek............................. 199

Stampede Creek.......................... 213

Steele Creek............................. 197

Stonehouse Creek . . .

Stuyahok area.......................... 159, 216, 217

Sulatna area........................... 159, 220-221

Sullivan Creek . ......................... 204, 205

Sunrise area ............................ 156, 173-174

Susitna River. See Cook Inlet-Susitna region.

Swanson Creek

Swode Gulch

Sweepstake area.
Sweek................................ 249

215

Switch Creek

$\mathrm{T}$

Talkeetna area . . . . . . . . . . . . . . . . . . . . 156, 177

Tamarack Creek............................. 221

Tatlanika area. . . . . . . . . . . . .

Taylor area ............................ 160, 245-246

Teller area....................... 161, 257, 258-259

Tenderfoot Creek............................ 219

Thunder Creek ............................. 176

Timber Creek.............................. 222

Tofty area

Toklat area ......................... 158, 211, 212-213

Tolovana district....................... 159, 222-225

Tolstoi area . . .................. 158, 208, 209-210

Totatlanika area............................ 157, 180

Trail Creek.............................. 221

Treasure Creek .............................. 194

Tripple Creek............................... 255

Tuluksak-Aniak district................. 159, 231-233

Tuluksak area . ........................... 159, 232

Twin Creek . . . . .

\section{$\mathrm{U}$}

Ungalik area ...................... 160, 247, 249-250

Upper Chatanika area.................. 157, 194-195

$\mathrm{V}$

Valdez Creek district.................... 157, 173, 177

Vault Creek.................................. 194

Vermont Creek............................. 215

Victor Gulch . ............................... 209

W

Wade Creek.............................. 201

Walker Fork are8..................... 158, 201

Wattamuse Creek.......................... 234, 235

West Coast area........................... 156, 174

West Creek................................... 261, 262

Wilbur area . . ......................... 159, 224-225

Wilbur Creek................................. 225

Willow area .............................. 158, 207

Willow Creek (Iditarod district) ........ 152-153, 207

Willow Creek (Marshall district) .............. 216

Willow Creek (Yentna district) ................ 176

Wilson Creek................................ 184

Wiseman area ........................... 158, 213-215

Wolf Creek .................................. 194

Wonder Creek

Wonder Gulch.......................... 246

Wood River area.......................... 157, 181

Woodchopper-Coal Creek area...... 157, 185, 188-189

Woodchopper Creek ....................... 205

\section{Y}

Yakataga district.................... 156, 166, 168-169

259 Yankee Creek ........................... 209

Yankee Creek $1 . . . \ldots \ldots . . .156,173,175-177$

Yukon region....... 152-153, 157-159, 162, 164, 178-225 